I NTER NATIONAL MONETARY FUND

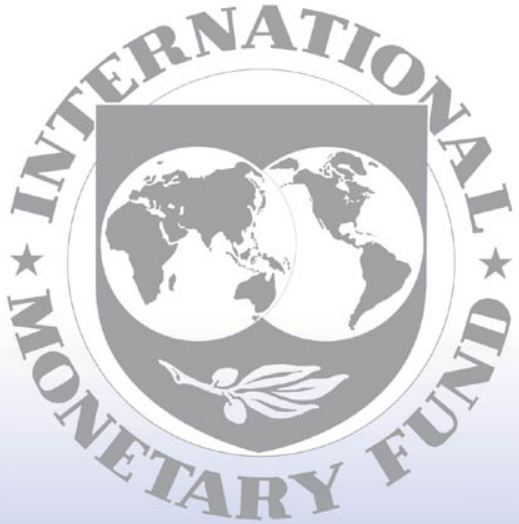

Staff

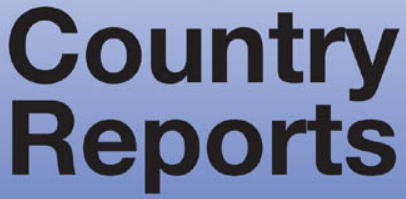




\section{Namibia: Selected Issues and Statistical Appendix}

This Selected Issues and Statistical Appendix paper for Namibia was prepared by a staff team of the International Monetary Fund as background documentation for the periodic consultation with the member country. It is based on the information available at the time it was completed on January 28, 2005. The views expressed in this document are those of the staff team and do not necessarily reflect the views of the government of Namibia or the Executive Board of the IMF.

The policy of publication of staff reports and other documents by the IMF allows for the deletion of market-sensitive information.

To assist the IMF in evaluating the publication policy, reader comments are invited and may be sent by e-mail to publicationpolicy@imf.org.

Copies of this report are available to the public from

International Monetary Fund • Publication Services

700 19th Street, N.W. • Washington, D.C. 20431

Telephone: (202) 6237430 • Telefax: (202) 6237201

E-mail: publications@imf.org • Internet: http://www.imf.org

Price: $\$ 15.00$ a copy

\section{International Monetary Fund \\ Washington, D.C.}


This page intentionally left blank

CInternational Monetary Fund. Not for Redistribution 


\section{INTERNATIONAL MONETARY FUND}

\section{NAMIBIA}

\section{Selected Issues and Statistical Appendix}

Prepared by Johannes Mueller (head), Patrick Akatu, Irene Yackovlev (all AFR), Koshy Mathai (FAD), and Manmohan Singh (ICM)

Approved by African Department

January 28,2005

Contents

I. The Macroeconomic Impact of HIV/AIDS in Namibia
A. Introduction
B. Targets and Outcome Indicators under MTP III
C. The Growth Accounting Framework
D. Fiscal Impact of HIV/AIDS
E. Conclusions

the Medium Term

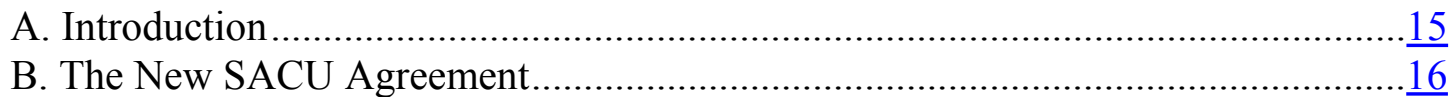

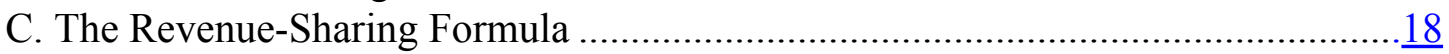

D. Namibia's Medium-Term Revenue Outlook ………............................................

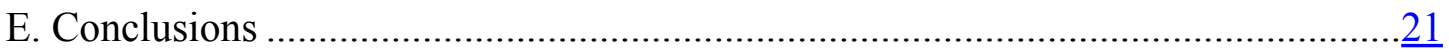

III. The Namibian Civil Service and the Government Wage Bill........................................23

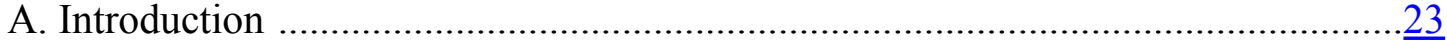

B. Namibia's Civil Service and Wage Bill in International Comparison......................23

C. Analysis of Namibia's Civil Service and Wage Bill Over Time and Across

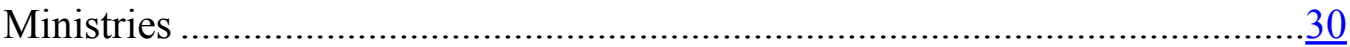

D. Civil Service Reform Efforts: Past, Present, and Future ……………………….... $\frac{36}{39}$

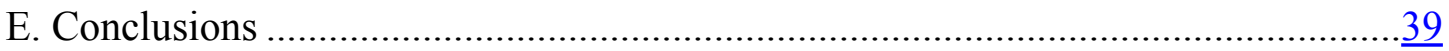

IV. International Reserves and Investment Decisions by Institutional Investors ....................41

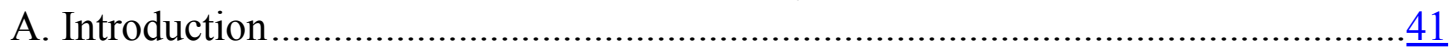

B. Namibia's Financial Sector ...............................................................................

C. Major Factors Behind Capital Outflows to South Africa.......................................44

D. Developing Domestic Financial Markets............................................................44

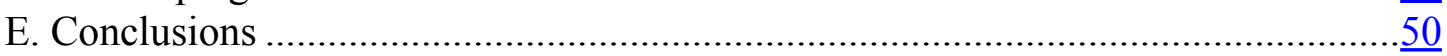


Boxes

I.1. Main Components of the National HIV/AIDS Strategy …….....................................

I.2. The Impact of MTP III on the Contribution of Human Capital to Growth ....................

II.1. Trade Policy Reform Under the New SACU Agreement ........................................ $\frac{17}{37}$

III.1. The World Bank and Civil Service Reform...........................................................

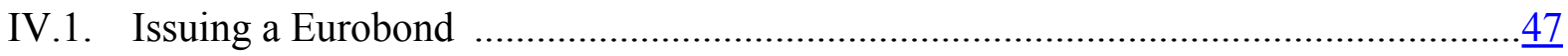

IV.2. Recent Widening in Namibian Bond Spreads Vis-à-Vis South Africa .......................49

Figures

I.1. Sources of Growth (Baseline Scenario) ……….................................................

I.2. Sources of Growth (Alternative Scenario)............................................................

II. 1. Actual and Projected SACU Revenue ……….....................................................

II. 2. Actual and Projected SACU Revenue With 25 Percent Development Component .....21

III.1. Selected African Countries: Wage Bill (percent of GDP) ..........................................24

III.2. Selected African Countries: Wage Bill (percent of total expenditure)...........................

III.3. Selected African Countries: Ratio of Average Government Wage to

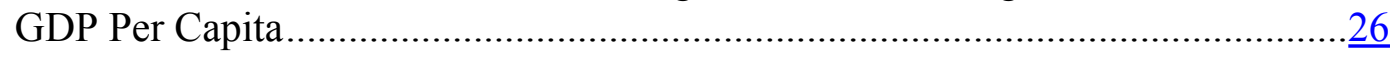

III.4. Selected African Countries: Central Government Employment..................................26

III.5. Selected African Countries: Civil Service Wage Bill Versus Employment ..................27

III.6. Regional and Income-Group Average: Civil Service Wage Bill Versus Employment 28

III.7. Selected African Countries: Armed Forces ……….............................................29

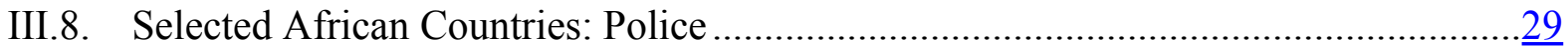

III.9. Central Government Wage Bill, 1995/96-2004/05 ................................................

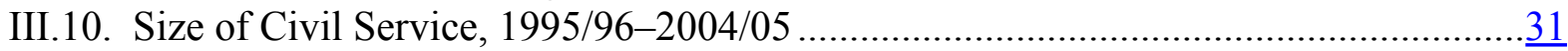

III.11. Percent of Established Positions Filled, by Vote, 2004/05 .........................................

III.12. Filled Civil Service Positions, by Vote, 1995/96-2004/05 ……………....................33

III.13 Shares of Total Personnel Expenditure, by Vote, 2004/05 .......................................

III.14. Average Compensation per Employee, by Vote, 2004/05 .........................................

III.15. Decomposition of Personnel Expenditure, 2004/05 ………..................................

III.16. Cash Allowances as a Percent of Monetary Compensation, by Vote, 2004/05............. $\frac{35}{42}$

IV. 1. Total Assets of Pension and Insurance Companies, 1995-2003 ……........................

IV. 2. Total Government Debt Outstanding, 1995-2004 ..................................................43

IV. 3. Capital Outflows and Bank Foreign Liabilities, 1999-2003 .....................................

Text Tables

I.1. Cost by Component as Estimated in MTP III .......................................................

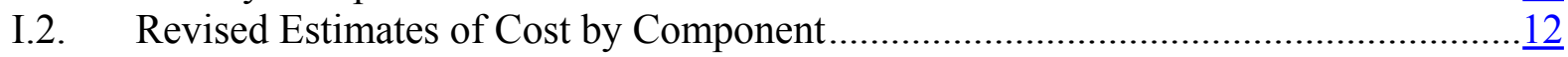

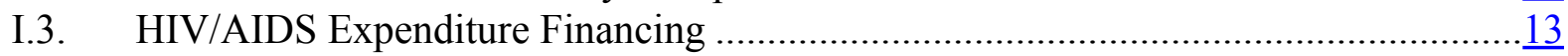

II.1. Projected Shares of the Common Revenue Pool, 2004/05 .......................................20

III.1. Public-Private Pay Differentials, 1995/96 …...........................................................

IV.1. Structure of Financial System, end-2003 .......................................................

IV. 2. Pension Funds Portfolio Limits and Actual Asset Allocation, 2001-02 …................. 
Tables

1. GDP and Gross National Income (GNI) at Current Prices, 1998-2003 ...................51

2. GDP by Industrial Origin at Current Prices, 1998-2003 .......................................52

3. GDP by Industrial Origin at Constant 1995 Prices, 1998-2003 (Namibia dollars) .... $\underline{53}$

4. GDP by Industrial Origin at Constant 1995 Prices, 1998-2003 (percentage change) $\underline{54}$

5. Expenditure on GDP, 1998-2003 ..........................................................55

6. Output of Selected Minerals, 1998-2003 .....................................................56

7. Harvest of Main Commercial Fishing Species, 1998-2003 ................................57

8. Consumer Price Index (Windhoek), January 2001-November 2004 ....................... $\frac{58}{59}$

9. Financial Operations of the Central Government, 1998/99-2003/04 .......................59

10. Central Government Revenue and Grants, 1998/99-2003/04 (Namibia dollars)......... $\underline{60}$

11. Central Government Revenue and Grants, 1998/99-2003/04 (percent GDP)............ $\underline{61}$

12. Central Government Expenditure, 1998/99-2003/04 (Namibia dollars).................... $\frac{62}{63}$

13. Central Government Expenditure, 1998/99-2003/04 (percent GDP) ......................63

14. Functional Classification of Central Government Expenditure, 1998/99-2003/04 _... $\underline{64}$

15. Sectoral Share of Central Government Expenditure, 1998/99-2003/04 ..................65

16. Outstanding Debt of Central Government, 1998/99-2003/04 ................................66

17. Monetary Survey, 1998-2003 ................................................................... $\frac{67}{68}$

18. Summary Accounts of the Bank of Namibia, 1998-2003 ......................................68

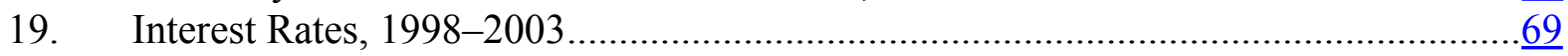

20. Financial Soundness Indicators, 1998-2003 ...................................................

21. Selected Indicators of Stock Exchange Activity, 1998-2003 ..................................

22. Balance of Payments, 1998-2003 (in millions of Namibia dollars ......................... $\frac{72}{73}$

23. Balance of Payments, 1998-2003 (in millions of U.S. dollars) ............................. 73

24. Merchandise Exports by Commodity Group, 1998-2003 .......................................

25. Mineral Exports, 1998-2003 …................................................................ $\frac{75}{76}$

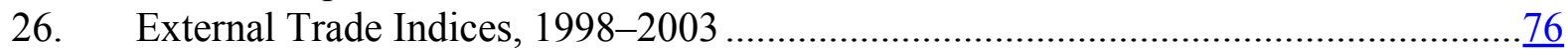

27. Merchandise Imports by Commodity Group, 1998-2003 ...................................

28. Imports (c.i.f) by Country of Origin, 1998-2003 ................................................ $\frac{78}{79}$

29. Exports by Country Destination, 1998-2003 ….............................................

30. Developments in the Exchange Rate of the Namibia Dollar, 1995-2004 .................

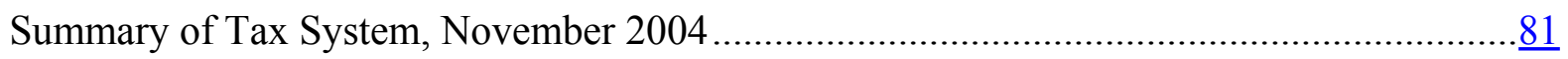




\section{The MACROECONOMIC IMPACT OF HIV/AIDS IN NAMIBIA 1}

\section{A. Introduction}

1. Namibia has one of the highest levels of HIV/AIDS prevalence in the world. The first cases of infection were detected in the late 1980s. By 1996, HIV/AIDS was the leading cause of death in Namibia. The growth in the number of people believed to be infected has been exponential since then. Today, one in five Namibians of ages 15 to 49 is believed to be HIVpositive, and UNAIDS estimates that 16,000 Namibians died of AIDS-related causes in 2003. As a consequence of increased mortality among young adults, the number of orphans in Namibia has also risen sharply and is expected to increase from 12 to 18 percent of the young population ages 0 to 17 by 2010 . In response to the seriousness and magnitude of the epidemic, Namibia began to formulate its coordinated HIV/AIDS strategies in the early 1990s. In 2004, Namibia published its third strategic plan to fight HIV/AIDS (MTP III). This comprehensive effort showcased the depth and widespread nature of the problem, stressing that HIV/AIDS is a development issue and not just a public health issue.

2. This chapter analyzes the macroeconomic impact of the HIV/AIDS pandemic, as well as its repercussions on fiscal policy. More specifically, the chapter seeks to assess the macroeconomic impact of HIV/AIDS under a successful implementation of MTP III that would lower the prevalence rate to below its 2004 level. It identifies the effect of HIV/AIDS on the real GDP growth rate over the medium term through a sources of growth model that estimates the impact of HIV/AIDS on the factors of production. In addition to highlighting the importance of increasing the contribution of human capital to growth, it also underscores the role of total factor productivity in sustaining growth rates that would allow for a reduction in poverty and unemployment.

3. The analysis shows that a full implementation of MTP III would pose significant challenges for Namibia, but is also a necessary step to sustaining growth over the medium term. To better illustrate the comparative statics, this chapter develops two scenarios for the sources of growth model. Differences in overall growth rates between the baseline and alternative scenarios illustrate the significant role that HIV/AIDS, and its abatement, can play in Namibia's development over the medium term when combined with prudent macroeconomic and structural policies. Under these assumptions, growth could average 4 percent over the medium term.

4. Implementation of MTP III would also require a reorientation of budgetary priorities. The estimated costs required to implement MTP III are expected to approach N\$1.4 billion (about $2 \frac{1}{2}$ percent of GDP) by 2009. The authorities expect that about one third of the cost would be financed by grants and participating NGOs. The remaining costs, however, would

\footnotetext{
${ }^{1}$ Prepared by Irene Yackovlev (AFR).
} 
need to be fully integrated into the medium-term expenditure framework in order to ensure adequate funding of HIV/AIDS programs.

5. This chapter is organized as follows. Section B discusses the targets and outcome indicators under MTP III. Section C discusses the growth expenditure framework and the baseline and alternative scenarios for growth in Namibia. Section D illustrates the fiscal impact of HIV/AIDS, while Section E presents the concluding remarks.

\section{B. Targets and Outcome Indicators under MTP III}

6. The third medium-term plan to fight HIV/AIDS (MTP III) represents a far-reaching and comprehensive strategy that aims to meet a complex set of quantitative and qualitative targets. The MTP III is built around five core components (Box I.1), which are complemented by benchmarks and quantitative targets to assess progress in the implementation of the strategy and to assign accountability to myriad actors charged with implementing MTP III. Four main targets deserve particular attention.

\section{Box I.1. Main Components of the National HIV/AIDS Strategy}

The third medium-term plan to fight HIV/AIDS encompasses the following five main components or areas of action:

1. Enabling environment: This component focuses on policy awareness and involvement. It details a series of actions, including the scheduling of donor conferences and the encouragement of a policy dialogue on HIV/AIDS. A key aspect of this component is that it reflects the authorities' intent to insure mainstreaming of the HIV/AIDS epidemic across all line ministries and agencies of government, as well as throughout the Namibian society.

2. Prevention: This component focuses on capacity building and increased awareness as ways to impede the continued spread of the HIV/AIDS virus. It sets aside funding for training workshops and public awareness campaigns, as well as for the training of health professionals involved in treating at-risk populations.

3. Treatment, care and support services: This component aims at highlighting the importance of increasing the capacity of the public health system to treat and care for the large number of those infected with HIV/AIDS and related diseases, such as tuberculosis. It also provides for highly active antiretroviral therapy to be made available to 25,000 patients by 2009 .

4. Impact mitigation services: This component recognizes the close link between poverty and the spread of HIV/AIDS. It calls for augmented poverty reduction efforts and assistance to AIDS orphans through grants and other services.

5. Integrated and coordinated program management: This component focuses on workshops and training to allow the authorities, NGOs, faith-based organizations, and others involved in the fight against HIV/AIDS in Namibia to coordinate and target their efforts. 
7. The first and most prominent target outlined in MTP III is a reduction in the incidence of HIV infection to below the epidemic threshold. Specifically, the MTP III establishes 2007 as the benchmark year by which the level of HIV seroprevalence should begin leveling off or declining. Accomplishing this task would allow Namibia to effectively meet one of the more prominent Millennium Development Goals (MDGs) which calls for halting or reversing the spread of HIV/AIDS by the year 2015. Although in its recent MDGs monitoring report Namibia indicated that progress toward meeting this goal had been slower than expected, the most recent sentinel survey finished at the end of 2004 suggests that the incidence rate of HIV/AIDS may already have begun to level off and could begin to decline well before 2007. This would represent a significant achievement in the fight against HIV/AIDS and greatly improve the chances of meeting the other targets set forth in MTP III.

8. The second major goal of the MTP III is to increase the number of persons living with HIV/AIDS who are receiving highly active antiretroviral therapy (HAART) from the current total of 3,000 to 25,000 by 2009 . The authorities estimate that even if this target is reached, only one in four of those eligible to receive HAART would be treated with antiretroviral therapies. However, these figures only include publicly funded and administered HAART and do not include the number of AIDS patients who could receive HAART through the private health care system or through donors operating outside the public health care system. The provision of HAART is crucial in terms of mitigating the potential impact of HIV/AIDS on growth. Those adults receiving HAART would in all likelihood be of working age, since most of those infected are between the ages of 15 and 49, and the ability to receive therapeutic drugs that abate the symptoms associated with infection would certainly prolong the average length of participation in the labor force and increase productivity.

9. MTP III also aims at halving the percentage of HIV-infected infants born to HIVinfected mothers from about 30 percent in 2005 to less than 15 percent in 2009 . Typically, the youngest are the most vulnerable among AIDS patients, and about half of infants born HIV-positive are unlikely to survive their first year. ${ }^{2}$ This target aims at building on Namibia's success in testing pregnant women for HIV and, taking it one step further, at ensuring that expectant mothers who are HIV-positive receive appropriate treatment during pregnancy and delivery.

10. The fourth major target is to increase the number of households with orphans receiving social welfare grants by 30 percent before 2007 and by 80 percent before 2009 , relative to 2005. All Namibian orphans are entitled to a small subsistence grant of N\$200 per month. However, in the past many orphans went without receiving this entitlement because they, or their caretakers, were unaware of its existence or unable to access the welfare system. MTP III calls for greater coordination among agencies, in concert with the new Ministry of Women's and Children's Affairs, to raise awareness and insure widespread

${ }^{2}$ U.S. Bureau of the Census. 
access to the orphan grants. However, the quantitative target in MTP III would still leave one in five orphans outside the social safety net.

\section{The Growth Accounting Framework}

\section{Description of Framework}

11. The past decade has seen a significant increase in studies of growth and its determinants. Particularly in the case of African countries, the question of why there has been so little growth continues to remain unanswered by both economists and policymakers alike. ${ }^{3}$ As Collins and Bosworth (2003) note, there is still no consensus among policymakers about which of the factors of production contribute the most to GDP growth nor about which approach - growth accounting or growth regressions - yields the most useful analytical results.

12. The growth accounting approach to analyzing economic growth is used to allocate historical levels of output between three main contributing factors: physical capital, human capital, and total factor productivity (TFP). In the standard growth accounting framework, physical and human capital contributions to growth may be calculated from largely observable sets of variables and with minimal additional assumptions. TFP is then calculated as the residual between the projected growth rate based on the calculated contributions of physical and human capital and the observed rate of economic growth. TFP captures the largely unobservable contribution of factors such as technological progress and overall gains in the efficiency of production. An increase in the contribution of TFP can signal an improvement in the overall efficiency of the economy or the assimilation of new technologies into production, such as more widespread use of information technology. However, as Hulten (2001) notes, because TFP is calculated as the residual of the growth equation, it captures all residual factors affecting growth, not just those related to technological progress. In countries such as Namibia, factors such as climatic and political shocks could also affect the residual.

13. The growth accounting framework uses a simple macroeconomic model based on a Cobb Douglas production function with constant returns to scale. The production function takes the following form:

$$
\mathrm{Y}=\mathrm{AK}^{\alpha}(\mathrm{LH})^{1-\alpha}
$$

where A represents total factor productivity, $\mathrm{K}$ represents physical capital and LH represent human capital, defined by the size of the labor force and calibrated for the overall level of educational attainment. While there is still not an absolute consensus in the economic literature on how to measure the contributions of capital and labor, there is increasing

${ }^{3}$ See O'Connell and Ndulu (2001). 
research to suggest that the capital and labor functions should each include certain essential features in the case of developing countries. As suggested in Bosworth and Collins (2003), the elasticity of output with respect to capital is assumed to be 35 percent. Physical capital in the framework is derived from a simple perpetual inventory model, where physical capital is a function of the capital stock in the previous year adjusted for depreciation ${ }^{4}$ and of fixed capital formation ${ }^{5}$ in the current year:

$$
\mathrm{K}=\mathrm{K}_{\mathrm{t}-1}(1-d)+\mathrm{I}_{\mathrm{t}}(2)
$$

The elasticity of output with respect to human capital (LH) is assumed to be 65 percent. The contribution of human capital to growth in this framework is a function of the size of the labor force $(\mathrm{L})$ and of educational attainment $(\mathrm{H})$. Additionally, educational attainment is itself a function of average years of schooling ( $\mathrm{s}$ ) as follows:

$$
\mathrm{H}=(1.07)^{\mathrm{s}}
$$

14. In this equation, estimated returns to schooling are such that an additional year of schooling raises education attainment by 7 percent. This is in keeping with the findings of most cross country studies. ${ }^{6}$

\section{Past Sources of Growth in Namibia}

15. In the past, physical and human capital have been important sources of growth in the Namibian economy. Over the last decade, growth averaged about 3.8 percent. The estimated contributions of physical capital and human capital to growth were roughly equal at around 1.0 and 1.2 percentage points, respectively. During the initial years after independence, Namibia aimed to build a high level of human capital in its labor force by drawing heavily on expatriate workers, but the country also recognized the need to build up the stock of human capital among its own native labor force. Today, Namibia has one of the highest average years of schooling in sub-Saharan Africa (almost 12 years), and mandates at least 10 years of schooling for every child. Many of those now entering the labor force benefited from increased investment in education following independence in the early 1990s, and over a quarter of government expenditure is currently earmarked for the education sector. Progress could still be made in increasing the efficiency of education expenditure, as highlighted by a public expenditure tracking survey conducted by the World Bank (2004).

16. TFP outpaced human and physical capital in its contribution to growth over the past few years, averaging 1.6 percentage points. This goes against the regional trend, but is not

\footnotetext{
${ }^{4}$ Depreciation of the capital stock is assumed to be 8 percent per year.

${ }^{5}$ Historical time series of fixed capital formation provided by the Bank of Namibia.

${ }^{6}$ See Barro and Lee (1993).
} 
surprising given Namibia's relatively sophisticated and well-maintained infrastructure and its high degree of openness, factors which could be assumed to facilitate technological transfer.

\section{Two Scenarios to Project Future Growth}

17. The framework as discussed above was applied to project two different growth scenarios. A baseline scenario is built on the assumption that the MTP III would be implemented successfully, complemented by the initiation of structural reforms and the pursuit of prudent macroeconomic policies. An alternative scenario would assume that the authorities fall short of expectations in all of these areas.

18. In order to quantify the growth impact of a successful MTP III implementation, the model makes some simplistic assumptions about the impact of MTP III on the contribution of human capital to growth (Box I.2).

\section{Box I.2. The Impact of MTP III on the Contribution of Human Capital to Growth}

The model assumes that HIV/AIDS affects the mortality and population growth rates, as well as the number of AIDS orphans. In order to quantify the impact of HIV/AIDS on the size of the general population and on the number of AIDS orphans, the following additional assumptions are made, in line with the quantitative targets discussed:

- The HIV/AIDS seroprevalence rate is assumed to level off by 2007 and to be declining slightly in 2008 and 2009.

- $\quad$ The number of HIV-infected infants born to HIV-infected mothers would decline from 30 percent in 2005 to 15 percent in 2009.

Using a demographic modeling software package ${ }^{1}$ the model is able to project trends in mortality and population growth as affected by differences in HIV/AIDS prevalence rates. The model assumes that under both scenarios, the labor force in Namibia is a fixed percentage of the population and thus, as mortality rates change, so should the size of the labor force and its corresponding contribution to human capital. Other studies (see Haacker 2004) have also attempted to link HIV/AIDS to declining educational attainment or worker productivity, but have been unable to quantify the impact. Given data constraints, it is not possible to make any quantifiable estimate of what the impact of HIV/AIDS on educational attainment and worker productivity might be. Thus, so as not to overstate the impact of MTP III on the contribution of human capital, the model adjusts only for the impact of HIV/AIDS seroprevalence and mortality rates on demographic trends, as projected by the simulations. The potential impact of MTP III on human capital is broadly in line with projections for strategies in neighboring countries such as Botswana. $^{2}$

${ }^{1}$ The software package is called SPECTRUM and is widely used by UNAIDS and others to project the epidemiological impact of the pandemic.

${ }^{2}$ For a detailed assessment of Botswana's AIDS strategy, see Masha (2004).

19. The baseline scenario assumes that growth would average about 4 percent over the medium term. This is the assumption underlying the macroeconomic framework in the accompanying staff report (1/27/05, www.imf.org) and is in line with the authorities' own targeted rate. 
20. The baseline scenario predicts that the contribution of human capital to growth would begin to increase, after being just

0.6 percentage point in 2004 . This is consistent with the assumption that the labor force would continue to grow again as the number of workers infected with HIV/AIDS begins to level off and decline. Another potential source of sustained human capital accumulation could result from enhanced vocational training programs which would in effect keep more Namibians in school longer, raise the level of educational

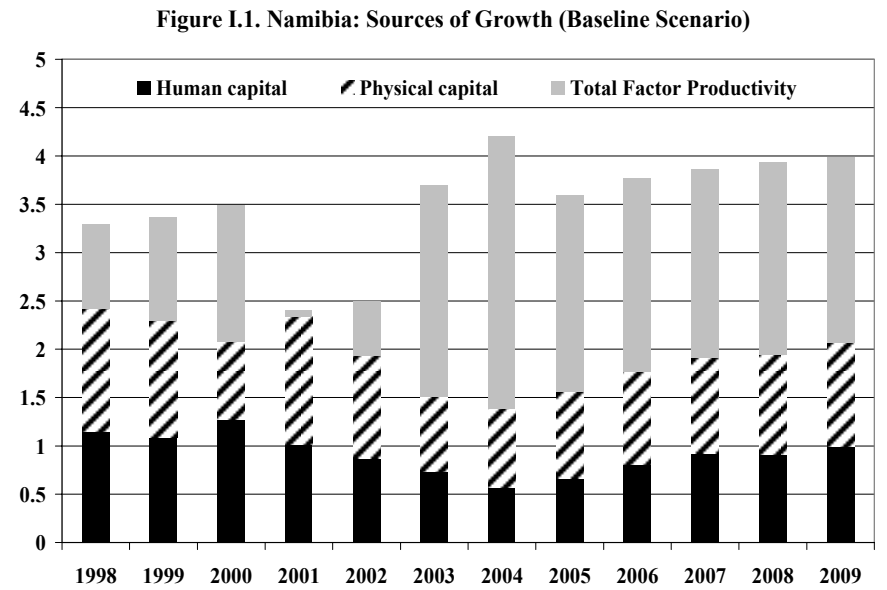
attainment, and more closely cater to the demands of the labor market. However, the average contribution of human capital to growth over the medium term, would still be just under 1 percentage point in the baseline scenario which is somewhat lower than its historical level. The baseline scenario projects that the contribution of TFP to growth would be around 2 percentage points. This is higher than the historical average but below the estimates for the two most recent years. Such a TFP contribution could result from the authorities' efforts to enhance skills, reform parastatals, promote SMEs, diversify exports, and increase labor market flexibility.

21. The alternative scenario shows a much different outlook over the medium term, with growth averaging just 3 percent. The change in the growth prospects for Namibia is quite stark when considering that only two assumptions have changed between scenarios. First, it is assumed in the alternative scenario that the MTP III is not fully implemented, and that there is therefore no recovery in the contribution of human capital to growth over the medium term. Instead, the contribution of human capital to growth is declining as the

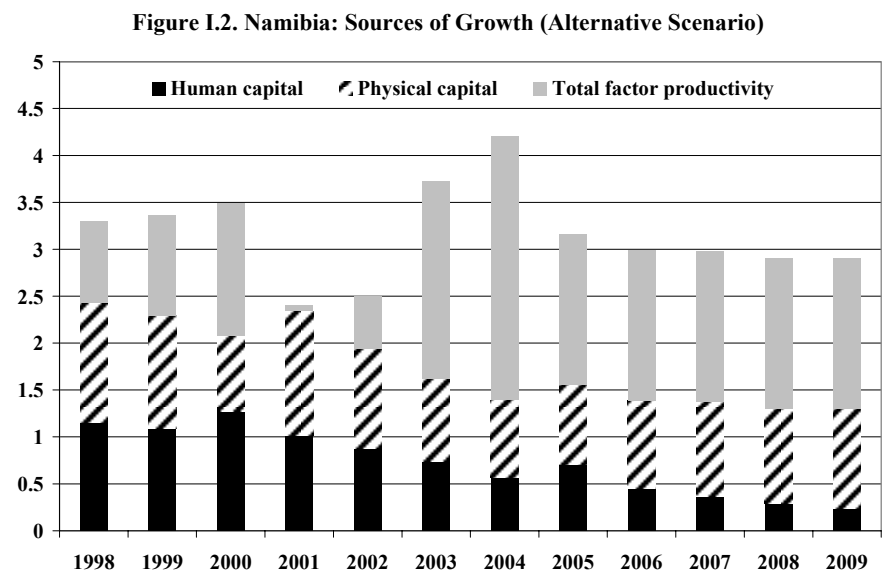
mortality rate continues to rise; as a result, the contribution of human capital to growth averages just about 0.4 percentage points. And second, it is also assumed that there is no increase in the rate of growth of TFP, reflecting that the structural reforms necessary to foster a sustained increase in productivity over time are not undertaken by the authorities. As the labor force gets sicker, productivity also declines. Thus, in the alternative scenario, the contribution of TFP to growth is held constant and set equal to its historical average. This formulation of the model is in keeping with other projections of the growth accounting 
framework for Africa such as Young (2000) and Masha (2004). The result is that growth averages nearly 1 percentage point lower over the next five years compared to the growth rate under the baseline scenario. This scenario means that without a successful implementation of MTP III, Namibia would struggle to maintain even a modest rate of growth over the medium term, and the average growth rate would be noticably below the targeted growth rate of 4 percent.

\section{Fiscal Impact of HIV/AIDS}

22. While a successful implementation of MTP III is essential for Namibia's economic growth, such a comprehensive program also requires careful consideration and planning in order to assure that it is adequately funded. The MTP III presents a rough breakdown of costs by component and projects that the total cost of implementing the strategy would be about N\$3.7 billion in the next five years.

\begin{tabular}{|c|c|c|c|c|c|c|}
\hline \multicolumn{7}{|c|}{$\begin{array}{l}\text { Text Table I.1. Namibia: Cost by Component as Estimated in MTP III } \\
\text { (In millions of Namibia dollars, unless otherwise indicated) }\end{array}$} \\
\hline & 2005 & 2006 & 2007 & 2008 & 2009 & $\begin{array}{r}2005-09 \\
\text { Cumulative }\end{array}$ \\
\hline Enabling environment & 11.2 & 11.1 & 9.9 & 7.8 & 7.8 & 47.8 \\
\hline Prevention & 255.3 & 236.3 & 237.7 & 193.5 & 196.4 & $1,119.2$ \\
\hline Equal access to treatment care and support services & 303.4 & 363.8 & 440.3 & 452.1 & 486.6 & $2,046.2$ \\
\hline Of which : HAART drugs & 36.0 & 86.9 & 152.7 & 163.3 & 191.8 & 630.7 \\
\hline Impact mitigation services & 48.0 & 63.8 & 38.6 & 47.8 & 88.5 & 286.7 \\
\hline Of which: subsistence grants to HIV/AIDS orphans & 0.0 & $\mathbf{0 . 0}$ & $\mathbf{0 . 0}$ & 0.0 & 0.0 & 0.0 \\
\hline Integrated and coordinated program management & 28.0 & 41.8 & 39.1 & 36.2 & 39.2 & 184.3 \\
\hline TOTAL MTP III COST & 645.9 & 716.9 & 765.6 & 737.4 & 818.5 & $3,684.3$ \\
\hline In percent of GDP & 1.7 & 1.7 & 1.7 & 1.5 & 1.5 & $\ldots$ \\
\hline
\end{tabular}

23. However, the actual cost of implementing MTP III is likely to be higher if the quantitative targets set out in the strategy are to be met. This mainly reflects (i) the substantially higher levels of funding needed for HAART treatment; and (ii) care and subsistence grants to HIV/AIDS orphans. To this end, two revisions to the cost as estimates in MTP III are incorporated into the projections and used in the baseline scenario.

24. The revised cost estimates indicate that a full implementation of MTP III would require nearly $\mathrm{N} \$ 5$ billion over the next five years. In the first revision, the estimated cost of the treatment and care services component is revised upwards largely so as to meet the quantitative target of providing HAART to 25,000 patients by 2009. The average estimated cost of providing HAART to patients in Namibia is currently N\$12,000 per year, ${ }^{7}$ and it is projected that the cost would rise slightly over time by about $\mathrm{N} \$ 1,000$ per year. In addition, the remaining estimated cost of providing non-HAART treatment and care services to people

${ }^{7}$ Estimated cost of HAART therapy provided by the Ministry of Health, Republic of Namibia. 
living with HIV/AIDS is assumed to rise slightly over time as well to keep pace with inflation. In keeping with the underlying assumptions of the MTP III cost projections, overhead and administrative costs are assumed to be 20 percent of the total cost of the component. In the second revision, the cost estimates published in the MTP III are increased to reflect funding for direct subsistence grants to HIV/AIDS orphans, as such grants are an entitlement under the law and providing such grants to at least 80 percent of orphans is one of the quantitative targets set in MTP III. Since these grants are an entitlement, the revised costs estimates assume that the target would be surpassed and that 100 percent of AIDS orphans would be receiving N\$200 a month grants by 2009. Currently, Namibia has close to 90,000 orphans, and approximately one-third of those are AIDS orphans. The demographic projections indicate that the number of AIDS orphans can be expected to more than triple over the next five years, meaning that over 100,000 AIDS orphans would be eligible for grants at an estimated cost of N\$240 million per year by 2009.

\begin{tabular}{|c|c|c|c|c|c|c|}
\hline \multicolumn{7}{|c|}{$\begin{array}{l}\text { Text Table I.2. Namibia: Revised Estimates of Cost by Component } \\
\text { (In millions of Namibia dollars, unless otherwise indicated) }\end{array}$} \\
\hline & 2005 & 2006 & 2007 & 2008 & 2009 & $\begin{array}{r}2005-09 \\
\text { Cumulative } \\
\end{array}$ \\
\hline Enabling environment & 11.2 & 11.1 & 9.9 & 7.8 & 7.8 & 47.8 \\
\hline Prevention & 255.3 & 236.3 & 237.7 & 193.5 & 196.4 & $1,119.2$ \\
\hline Equal access to treatment care and support services & 313.9 & 368.9 & 459.6 & 651.0 & 757.4 & $2,550.8$ \\
\hline Of which : HAART drugs & 36.0 & 70.2 & 140.0 & 300.0 & 400.0 & 946.2 \\
\hline Impact mitigation services & 48.0 & 135.8 & 197.0 & 263.8 & 376.5 & $1,021.1$ \\
\hline Of which: subsistence grants to HIV/AIDS orphans & 0.0 & 60.0 & 132.0 & 180.0 & 240.0 & 612.0 \\
\hline Integrated and coordinated program management & 28.0 & 41.8 & 39.1 & 36.2 & 39.2 & 184.3 \\
\hline TOTAL MTP III COST & 656.3 & 794.0 & 943.3 & $1,152.4$ & $1,377.3$ & $4,923.3$ \\
\hline In percent of GDP & 1.7 & 1.9 & 2.1 & 2.3 & 2.5 & \\
\hline
\end{tabular}

25. Despite donor support, the full implementation of MTP III would still require significant additional budgetary expenditure - which should be accommodated. Namibia has received approval for funding request from the two major international donors in the fight against HIV/AIDS: the Global Fund to Fight HIV/AIDS and the President's Emergency Program for AIDS Relief (PEPFAR). Combined the Global Fund and PEPFAR grants should amount to over N\$1.7 billion in grant-funded expenditure for HIV/AIDS. Additionally, MTP III envisions that domestic NGOs already active in the fight against HIV/AIDS would directly contribute about 5 percent of the direct financial cost of implementing the strategy, or roughly N\$250 million. Despite these significant contributions, total annual budgetary expenditure required for HIV/AIDS would increase from about N\$350 million in 2005 to over N\$900 million by 2009. This means that up to 1.7 percent of GDP in additional expenditures would need to be accommodated by the budget by 2009 if full implementation of the MTP III is to occur. 


\begin{tabular}{|c|c|c|c|c|c|c|}
\hline \multicolumn{7}{|c|}{$\begin{array}{l}\text { Text Table I.3. Namibia: HIV/AIDS Expenditure Financing } \\
\text { (In millions of Namibia dollars, unless otherwise indicated) }\end{array}$} \\
\hline & 2005 & 2006 & 2007 & 2008 & 2009 & $\begin{array}{r}2005-09 \\
\text { Cumulative }\end{array}$ \\
\hline Total estimated cost of MTP III Implementation & 656.3 & 794.0 & 943.3 & $1,152.4$ & $1,377.3$ & $4,923.3$ \\
\hline Minus: $5 \%$ financial contribution of NGOs to program & 32.8 & 39.7 & 47.2 & 57.6 & 68.9 & 246.2 \\
\hline Total public expenditure on HIV/AIDS (including grants) & 623.5 & 754.3 & 896.1 & $1,094.8$ & $1,308.4$ & $4,677.1$ \\
\hline Minus: Grant funded expenditure & 272.4 & 325.4 & 373.5 & 373.5 & 373.5 & $1,718.3$ \\
\hline Of which: Global Fund for HIV/AIDS & 98.6 & 98.6 & 199.7 & 199.7 & 199.7 & 796.3 \\
\hline PEPFAR & 173.8 & 226.8 & 173.8 & 173.8 & 173.8 & 922.0 \\
\hline Total public expenditure on HIV/AIDS (excluding grants) & 351.1 & 428.9 & 522.6 & 721.3 & 934.9 & $2,958.8$ \\
\hline In percent of GDP & 0.9 & 1.0 & 1.1 & 1.4 & 1.7 & $\ldots$ \\
\hline
\end{tabular}

26. The additional resources needed to win the fight against HIV/AIDS require a reorientation of budgetary spending priorities. However, as the sources of growth model illustrates, a successful implementation of MTP III is essential to growth over the medium term.

\section{E. Conclusions}

27. The MTP III is a comprehensive and ambitious strategy to address the challenges posed by the HIV/AIDS epidemic. Full implementation of MTP III as envisioned would significantly improve Namibia's growth prospects, by increasing the contribution of human capital to growth over the medium-term. However, in order to sustain an average growth rate of 4 percent over the medium term, an increase in the contribution of TFP to growth would also be necessary.

28. Given its track record of relatively good governance and sound macroeconomic management, Namibia could significantly improve the contribution of total factor productivity to growth. Namibia's overall favorable business climate, relatively good infrastructure and the initiation of structural reforms should facilitate technological transfer and enhanced efficiency.

29. Despite significant donor support, the full implementation of MTP III would require significant additional public expenditure which should be accommodated. By 2009, an estimated 1.7 percent of GDP would need to be set aside to fund MTP III. This would require a reorientation of budgetary spending priorities in order to ensure adequate funding for MTP III, particularly in terms of orphan grants and treatment and care services, including for the provision of HAART. 


\section{References}

Barro, R. and J-W. Lee (1993), "International Comparisons of Educational Attainment," Journal of Monetary Economics 32(3), december:363-394.

Bosworth, B. and S. Collins (2003), "The Empirics of Growth: An Update". Background paper for the AERC Explaining African Economic Growth Project, mimeo, September.

Haacker, Markus (2004), "The Impact of HIV/AIDS on Government Finance and Public Services," in M. Haacker (editor) The Macroeconomics of HIV/AIDS. Washington, DC: International Monetary Fund. Pp. 298-258.

Hulten, C. R. (2001), “Total Factor Productivity: a Short Biography.” In C. Hulten, E. R. Dean, and M. Harper (editors) New Developments in Productivity Analysis, Studies in Income and Wealth Vol. 63. Chicago: University of Chicago Press. Pp. 1-54.

Masha, Iyabo (2004), "An Economic Assessment of Botswana's National Strategic Framework for HIV/AIDS," in M. Haacker (editor) The Macroeconomics of HIV/AIDS. Washington, DC: International Monetary Fund. Pp. 287-310.

O'Connell, Stephen A. and Benno J. Ndulu (2000), “Africa's Growth Experience: A Focus on Sources of Growth," Background paper for the AERC Explaining African Economic Growth Project, mimeo, September.

Young, A. (2000). "Gold into Base Metals: Productivity Growth in the People's Republic of China During the Reform Period." Working paper 7856. Cambridge, MA: National Bureau of Economic Research (August), 


\section{The New SACU Agreement And Namibia's Revenue OUtlook Over the MEDIUM TERM $^{8}$}

\section{A. Introduction}

30. The Southern African Customs Union (SACU) agreement concluded in 2002 was ratified by the legislatures of the five member countries - South Africa, Botswana, Lesotho, Namibia, and Swaziland - and came into force in 2004. The new agreement aims at transforming the customs union, which had previously vested major decision-making authority in South Africa, into a supranational organization, with more balanced rights and obligations among members. The transition to the new regime reaches an important stage in 2005 , with the coming into effect of a new revenue-sharing formula (RSF) that entails a reduction in the shares of Botswana, Lesotho, Namibia, and Swaziland (BLNS) in the common revenue pool (CRP), as South Africa ends its subsidy of the CRP and becomes a full-fledged participant in the sharing of revenue.

31. The previous 1969 agreement assigned to South Africa the authority for setting trade policy. This included formulating policies on the common external tariff, the use of rebates, anti-dumping measures, and countervailing duties. As a result, SACU's trade policies were set in line with South Africa's industrial development priorities, which given the huge difference in the stages of development, did not necessarily coincide with those of BLNS. This group of countries had also become dissatisfied with the revenue-sharing formula, which had evolved into an arrangement for allocating tariff revenue to BLNS based on criteria that were increasingly unsustainable. The new agreement addresses both of these concerns.

32. This chapter reviews the scope of the reforms envisaged by the Agreement, the challenges they present especially for the BLNS countries, and the revenue implications of the new revenue-sharing formula for Namibia over the coming years. It finds, based on preliminary estimates of Namibia's share of the CRP, that the country's SACU receipts will fall by up to $2 \frac{1}{2}$ percent of GDP in 2005/06 compared with the previous year. This decline is expected to continue over the medium term, reaching 4 percent of GDP by 2009/10 compared with $2004 / 05$ and $2 \frac{1}{2}$ percent of GDP relative to its projected level if the previous revenue-sharing formula were to continue to apply. On the other hand, the Agreement emphasizes reforms aimed at promoting integration with the global economy, fair competition, increased investment, and economic development of the member countries. The pace of implementation will depend on the success of the BLNS in addressing capacity constraints in areas such as tariff and trade remedy investigations where experience and expertise are lacking. Improving the quality and timeliness of national accounts and trade statistics has also become an urgent challenge in light of the requirements of the new revenue-sharing formula.

${ }^{8}$ Prepared by Patrick Akatu (AFR). 
33. In the section that follows, the institutional arrangements of the new Agreement and some of the challenges that the SACU faces as it makes the transition to a democratic customs union are highlighted. Section $\mathrm{C}$ presents an overview of the revenue-sharing arrangement as it has evolved over the years and outlines the main elements of the new revenue formula. Section D focuses on the revenue implications of the new formula for Namibia over the next several years, and Section E summarizes the conclusions.

\section{B. The New SACU Agreement}

34. The new Agreement provides for the establishment of the Council of Ministers, the Customs Union Commission, the Secretariat, the Tariff Board, four Technical Liaison Committees, and an Ad-hoc Tribunal:

- $\quad$ The Council of Ministers is composed of one minister from each member country and is the highest decision-making authority. The Council appoints the Executive Secretary of SACU. Decisions of the Council and all other SACU institutions are to be made on the basis of consensus.

- The Customs Union Commission supervises the work of the SACU Secretariat, oversees the management of the common revenue pool, and has responsibility for the implementation of the Agreement. It is composed of senior officials from each member state.

- The Secretariat is the administrative organ of SACU. It is headed by the Executive Secretary and is located in Windhoek, Namibia.

- The Tariff Board advises the Council of Ministers on all changes to the common external tariff as well as anti-dumping, countervailing and safeguard duties on imports from nonmember countries. It is an independent body and is composed of experts drawn from member countries.

- $\quad$ Four Technical Liaison Committees are to assist and advise the Customs Union Commission in its work in the areas of agriculture, customs, trade and industry, and transport.

- $\quad$ The Ad-hoc Tribunal is empowered to settle all disputes on the interpretation or application of the Agreement at the request of the Council of Ministers. The Tribunal reaches its decision by a simple majority, and its decision is final. Parties to a dispute choose members of the Tribunal from a list approved by the Council of Ministers.

35. Under the Agreement, external trade policy-including tariff changes - requires the concurrence of the Council of Ministers to become effective. In the meantime, the existing common external tariff rates and tariff policy more generally will continue to apply. The Agreement calls for the adoption of common policies in industry, agriculture, competition, and unfair trade practices. As a first step, each member is to develop national policies in each of these areas. In addition, members are to harmonize customs procedures, product standards, and technical regulations as part a broad set of reforms aimed at promoting integration with 
the global economy (Box II.1). The Agreement retains the infant industry provisions of the 1969 Agreement, under which BLNS can impose duties on imports from South Africa provided the same duties are also imposed on imports from the rest of the world.

\section{Box II.1. Trade Policy Reform Under the New SACU Agreement}

The 2002 SACU Agreement places emphasis on strengthening trade liberalization, including within the union, and spreading the benefits of trade among its members. The stated objectives of the Agreement include: facilitating the cross-border flow of goods among member countries; the establishment of democratic institutions to govern the affairs of the customs union; and the promotion of fair competition across the region.

Since the mid-1990s, trade liberalization has gathered pace. The tariff structure has been simplified to some extent and the simple average MFN duty rate has been reduced to 11 percent in 2002 from 15 percent in 1997. Consideration is also being given to reducing the number of tariff lines. Under the new Agreement, it is envisaged that existing tax and nontax measures that impede the free flow of trade within the customs union will be addressed and the union's technical standards would be brought in line with members' commitment under the WTO. The importance attached to trade liberalization is also evident in the ongoing efforts to reach free trade agreements with other regional trade areas and countries.

Notwithstanding the progress made, the external tariff structure remains complex. It comprises ad valorem, specific, mixed, and formula duties. The need for progress in further simplifying the tariff structure will test the tariff review process mandated under the new agreement. Within SACU, significant differences in internal taxes on cross-border trade flows constitute a source of distortion that reduces the benefits of the customs union to its members. Presently, goods imported into the SACU area are in general subject to customs duties, levies, VAT or sales tax as the case may be, and each country sets its own VAT or sales tax rate. Botswana, Lesotho, Namibia, and South Africa levy VAT at different rates, while Swaziland applies a sales tax. ${ }^{1}$

The SACU presently lacks a common approach in key areas of trade policy, such as customs procedures, standards, and technical regulations. South Africa's standards are generally in use in Namibia and Lesotho, while Botswana and Swaziland both have adopted separate standards. To address this drawback and facilitate cross-border movement of goods within the customs union and with the rest of the world, the new Agreement requires that members harmonize product standards within the customs area and apply product standards and technical regulations in accordance with the WTO Agreement on Technical Barriers to Trade. The use of anti-dumping, countervailing, and safeguard measures is another area that has been prioritized for reform in the new Agreement, with a view to consolidating the liberalization of members' markets.

Trade liberalization in a regional context has continued. In 2000, South Africa reached a trade agreement with the EU that, with the concurrence of the BLNS, is expected to create a free trade area in industrial and agricultural goods over a ten-year period. The SACU recently concluded a regional trade agreement with the MERCOSUR and is engaged in the Economic Partnership Agreement with the EU. Negotiations are also ongoing with the United States on a free trade arrangement scheduled to be concluded in 2005. The SADC to which all SACU countries belong is working toward establishing a free trade area by 2008. In addition, consideration is being given to preferential trade arrangement with a number of countries including India, China and Nigeria.

\footnotetext{
${ }^{1}$ As a consequence, when goods are exported from one SACU country to another, the shippers apply for VAT or sales tax refunds from the exporting country, and then pay the relevant tax to the importing country. The differences in internal taxation between SACU members increase transactions costs for traders, thereby encouraging smuggling and tax evasion, and other forms of distortion in flow of trade.
}

36. However, the lack of experience and expertise may pose major challenges for the BLNS. Trade policy including tariff setting, the development of common policies including in industry, and effective participation in SACU level trade negotiations are areas that are of particular importance to the growth prospects of the member countries. 
37. Beyond these, there are aspects of the SACU Agreement whose implementation are likely to raise difficult problems. First, the consensus approach to setting tariffs and other trade policies could work in favor of the status quo rather than for reforms aimed at realigning them with the development priorities of the of the union as a whole. Second, the Agreement provides for the management of the CRP by South Africa during an interim period of two years. However, there is as yet no agreement on the modalities for a permanent arrangement, one that ensures competent management of the CRP and is politically acceptable to all members. Third, the new Agreement continues to exclude trade in services, being limited only to the trade in goods.

\section{The Revenue-Sharing Formula}

38. Two elements of the SACU revenue arrangement have remained essentially unchanged since its inception in 1910. First, the CRP has continued to derive its resources from customs and excise revenue collected in the member countries. ${ }^{9}$ Second, the common external tariff (CET) which forms the basis of the union's customs revenue-in accordance with the union's past agreements and, for the time being, under the new Agreementremains South Africa's customs tariff.

39. The RSF, by contrast, has undergone a number of modifications over the years. Under the 1910 formula, the CRP was distributed on the basis of fixed percentage shares that were unrelated to members' trade. Under that arrangement, South Africa received 98.7 percent of the revenue pool. The attainment of sovereignty by Botswana, Lesotho, and Swaziland (BLS) in the 1960s gave rise to the 1969 SACU agreement, which introduced a compensatory element into the RSF. In particular, the RSF was formulated in such a way as to provide some compensation to the BLS for the cost of trade diversion associated with the CET that was determined solely by South Africa's industrial policy. ${ }^{10}$ Under the modified RSF, the CRP was allocated on the basis of SACU imports and excisable goods. Allocations to BLS had two components: a portion based on their share in imports and excise revenue; and a compensatory component set at 42 percent on their CRP receipts. ${ }^{11}$ South Africa's

${ }^{9}$ In Bank of Namibia (2003), it is suggested that the reason for including excise revenue in the CRP in the beginning was administrative convenience. Including excise revenue in the common pool made it relatively easy to prevent the evasion of excise taxes by simply shipping excisable goods produced in South Africa to the BLNS as exports and then shipping them back to sell in South Africa.

${ }^{10}$ The agreement also contained infant industry protection provisions to allow the BLNS pursue their own industrial policies.

${ }^{11}$ Namibia not being a sovereign country in 1969 was not a party to the 1969 agreement but continued to be allocated a share of the CRP under a series of ad-hoc decisions until 1992/93. 
share of revenue was determined as a residual. Actual distributions to members were computed on the basis of revenue collections with a two-year lag.

40. The 1969 formula was modified in 1997 with the introduction of the "stabilized revenue rate." Under the 1997 formula, the BLNS as a group were guaranteed a minimum of 17 percent and a maximum of 20 percent of the total value of SACU imports and excisable goods, without regard to prevailing import tariffs. ${ }^{12}$ In practice, this formula, which based the distribution of revenue to BLNS on the revenue base of the CRP, rather than on actual revenue collections, has largely worked in favor of the BLNS whose share of the pool has increased over time, partly because of the progressive reduction in customs tariffs.

41. The 2002 Agreement introduced three major changes in the revenue-sharing formula: (i) all members' shares (including South Africa's, which had been a residual under the previous agreement) are determined within the formula; (ii) the total amount distributed to members is limited to the estimated size of the revenue pool; and (iii) each member's share is made up of three components, namely customs, excise, and development. The customs component is distributed according to each country's share of intra-SACU imports. The excise component - comprising 85 percent of excise revenue collections - is distributed on the basis of each country's share of total SACU GDP, and the development component, currently set at 15 percent of excise revenue, is distributed in broad proportion to the deviation of a member's per-capita GDP from the SACU average. By allocating the customs pool according to shares of intra-SACU imports rather than total SACU imports, the formula seeks to compensate members for the costs associated with trade diversion. The development component provides additional compensation to the least developed member countries.

42. Under the new formula, the BLNS would derive most of their CRP receipts from the customs component. Based on a hypothetical exercise for 2004/05 - the new formula will only become effective in 2005/06 - they would have accounted for a total of 81 percent of the estimated customs collections in 2004/05 (Text Table II.1). By contrast, some 91 percent of the projected excise component would have been allocated to South Africa. Lesotho and Swaziland would both have benefited from the redistributions under the development component, measured by the extent to which their shares each exceeds 20 percent (or an equal distribution to the five member countries). On the other hand, South Africa, which under the formula would have received about 80 percent of the total excise revenue - instead of about 91 percent if distribution of all excise revenue was based on its share of SACU GDP - would have been the sole net contributor to the development component. The shares of BLNS in total excise revenue are each expected to be higher than would be the case if distributions were based on their respective shares of SACU GDP.

${ }^{12}$ Imports for this purpose include intra-SACU imports on which no duties are collected. 
Text Table II.1. SACU: Projected Shares of the Common Revenue Pool, 2004/05 1/

(In percent; unless otherwise indicated)

\begin{tabular}{|c|c|c|c|c|c|c|}
\hline & Botswana & Lesotho & Namibia & Swaziland & $\begin{array}{c}\text { Total } \\
\text { BLNS }\end{array}$ & $\begin{array}{r}\text { South } \\
\text { Africa } \\
\end{array}$ \\
\hline Share of customs component & 35.4 & 12.2 & 21.0 & 12.0 & 80.6 & 19.3 \\
\hline Share of excise component & 5.0 & 0.65 & 2.70 & 1.04 & 9.4 & 90.6 \\
\hline Share of development component & 18.3 & 21.7 & 19.9 & 20.8 & 80.7 & 19.4 \\
\hline Total share & 21.2 & 8.0 & 13.2 & 8.0 & 50.4 & 49.5 \\
\hline \multicolumn{7}{|l|}{ Memorandum items: } \\
\hline Total share of excise revenue & 7.0 & 3.8 & 5.3 & 4.0 & 20.1 & 79.9 \\
\hline Percent of SACU GDP & 5.0 & 0.7 & 2.7 & 1.0 & 9.4 & 90.6 \\
\hline Intra-SACU imports (in million Namibia dollars ) & $4,283.4$ & 78.7 & $2,541.0$ & $1,452.0$ & $\ldots$ & $2,335.3$ \\
\hline
\end{tabular}

Source: Bank of Namibia (2003); and staff estimates.

1/ Based on the new SACU revenue sharing formula. Totals may not add to 100 due to rounding.

43. The new agreement also makes important changes to the way in which revenue shares are calculated, managed, and distributed. Members' shares of each component of the revenue pool are calculated once from the most recent and audited trade, GDP, and per-capita GDP data and are not subject to adjustment in future years for estimation error. ${ }^{13}$ The shares are then applied to agreed customs and excise revenue forecasts, subject to adjustment in the ensuing two years to reflect revisions in estimates and then actual revenue collections. South Africa is to continue to manage the pool and payments for the first two years of the Agreement while a permanent arrangement is being devised. SACU government representatives and the Secretariat are to meet once a year in October or November to agree on these computations and also decide on the quarterly allocations of revenue beginning in April of each year. Members will continue to transfer their collections of revenue to the pool on a quarterly basis, with the first one under the new Agreement due in September 2005. ${ }^{14}$

\section{Namibia's Medium-Term Revenue Outlook}

44. The staff's projection of Namibia's SACU receipts for 2005/06 are based on recent projection of the CRP through 2007/08 obtained from the Namibia authorities. The projections are subject to more than the usual uncertainty as SACU makes the transition from the old to the new formula. One important element of the evolving practice is the decision for pragmatic reasons to use the 2003 rather than 2004 GDP figures as basis for computing members' shares of the CRP in 2005/06. Member countries agreed to set Namibia's share in

\footnotetext{
${ }^{13}$ Subsequent revisions of data do not attract penalties or rewards since the revenue shares cannot be adjusted after they have been agreed. There is, therefore, no incentive to avoid the normal updating of statistics as better information becomes available.
}

${ }^{14}$ This has raised the issue of how revenue allocations due in April and July 2005 would be financed, since all the resources in the pool under the old formula would have been paid out. 
the customs pool at about 27 percent for $2005 / 06$, but this share is projected to decline to about $24 \frac{1}{2}$ percent through $2009 / 10$. The country's share of the excise pool would average about 2.4 percent, and the country could come out even, with no net transfers on the development component.
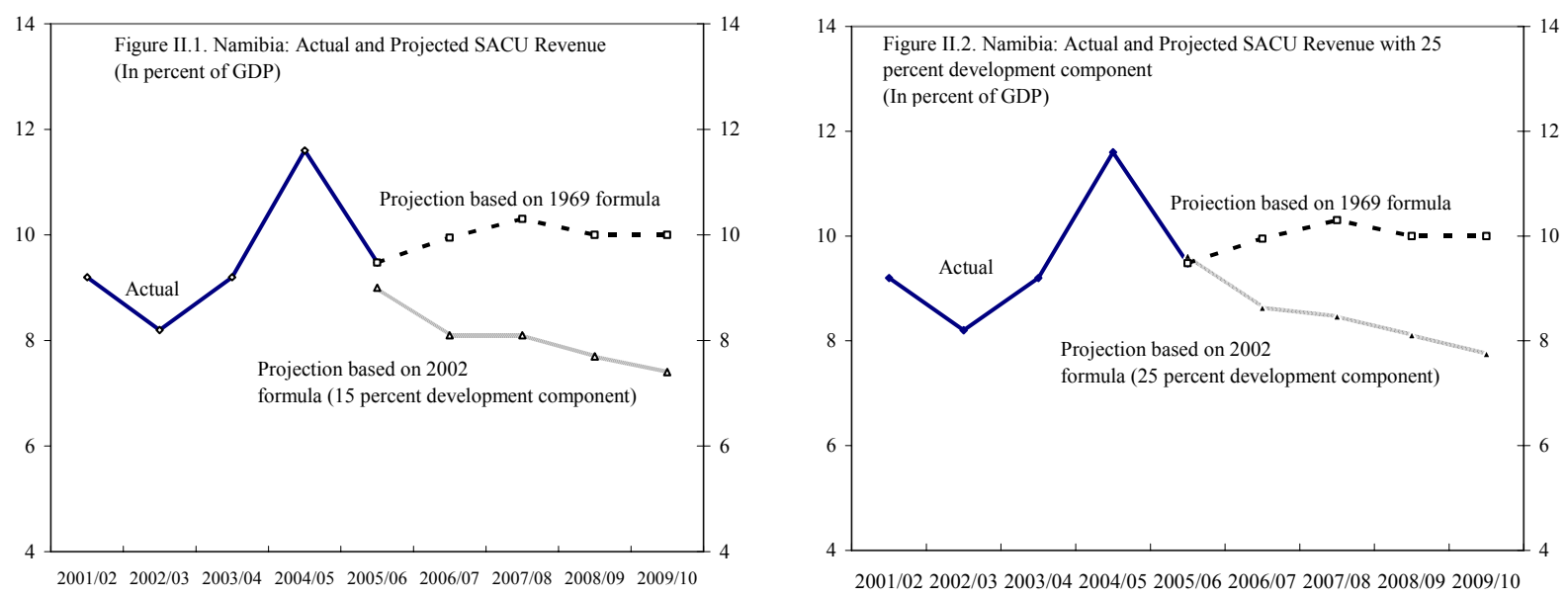

45. On these assumptions, Namibia's SACU revenue is projected to decline significantly with the application of the new revenue-sharing formula (Figure II.1). ${ }^{15}$ The decline relative to the old formula rises to up to about $2 \frac{1}{2}$ percent of GDP by 2009/10. The Agreement provides for the periodic review of the development component, which would be one way to increase the resources distributed to BLNS to enable them cope better with the decline in receipts. ${ }^{16}$ An increase in the development component to 25 percent could improve Namibia's SACU receipts by about one-half percent of GDP by 2009/10 (Figure II.2).

\section{E. Conclusions}

46. The new Agreement moves the SACU toward closer consultation and increased policy coordination, with the potential for increased benefits for all members. The internal transformation coincides with new initiatives aimed at advancing trade liberalization at the regional and multilateral level. This has presented various challenges to develop common policies, including in the area of industry and competition, and to harmonize internal taxes, customs procedures, and technical standards that presently hamper trade flows within the customs union and third countries. A more immediate priority is establishing a functioning Tariff Board, able to mediate between the various interests of the members in setting policy

\footnotetext{
${ }^{15}$ The sharp increase in 2004/05 reflected the additional distribution of revenue that had accumulated in the CRP under the 1969 formula. These undistributed balances arose from the two-year lag between the collection of customs revenue and the payment of SACU receipts.
}

${ }^{16}$ South African Customs Union Agreement 2002, Annex “A” section 3(a). 
instruments and providing a common platform for SACU's bilateral and multilateral trade negotiations, as envisaged in the Agreement. In all these areas, the BLNS face capacity constraints that need to be addressed to enable them to participate effectively in the reformed SACU.

47. Despite the uncertainties that remain, the BLNS could face a significant fiscal adjustment as the new revenue-sharing formula comes into effect in 2005/06. In the case of Namibia, the decline in revenue could reach 4 percent of GDP by 2009/10 compared with $2004 / 05$ and about $2 \frac{1}{2}$ percent compared with projected receipts under the old formula. An increase in the proportion of excise collections allocated to the development component could help ease the adjustment. However, adjustment on the scale that has been considered would not substantially offset the revenue decline, even abstracting from the expected decline in customs revenue in real terms over the medium term, as tariff rates are reduced in line with commitments under the existing trade agreements.

48. Namibia also needs to step up efforts to improve the reliability and timeliness of its statistics including in particular, trade and national accounts data, as any understatement in these areas would result in loss in SACU receipts that could not be recouped later.

\section{References}

Bank of Namibia (2003), "Challenges and Implications of the 2002 SACU Agreement," Bank of Namibia.

IMF (2003), “The New SACU Agreement and its Effect on Revenue,” International Monetary Fund.

Kirk, R. and R. Stern (2003), "The New Southern African Customs Union Agreement," African Region Working Paper Series No. 57, June 2003, The World Bank.

WTO (2003), “Trade Policy Review, Southern African Customs Union," Report by the Secretariat, Geneva, November 2003, World Trade Organization. 


\section{The Namibian Civil Service and the Government Wage Bill ${ }^{17}$}

\section{A. Introduction}

49. Namibia faces a difficult fiscal situation over the medium term. As discussed in more detail in the accompanying staff report (1/27/05, www.imf.org), revenues are projected to fall sharply over the medium term, largely as a result of reduced SACU receipts, while new spending needs have emerged, in particular to implement the government's HIV/AIDS strategy. At the same time, the authorities are committed to keeping their public debt at sustainable levels, which implies the need for generating moderate primary surpluses over the next few years.

50. Within these constraints, a reorientation of government spending seems unavoidable, and Namibia's large government wage bill is a prime candidate to generate savings. This chapter seeks to identify the reasons behind the high wage bill, in order to identify possible priorities for future reform. Analysis of cross-country data indicates that the main issue is an overly large, rather than an overly paid, civil service. This suggests that, in addition to the authorities' strategy of pursuing multi-year wage settlements and containing wage increases below inflation, some thought may need to be given to reducing the size of the civil service. Having a smaller civil service would also allow the decompression of wage scales and increased remuneration for senior officials who are undercompensated relative to the private sector.

51. The rest of the chapter is organized as follows. Section B uses cross-country data to put Namibia's civil service and wage bill in a broader international context and point toward potential areas of concern. Section $\mathrm{C}$ relies on more detailed Namibian data to assess how employment, the wage bill, and wages have evolved over time and how they compare across different ministries. Section D discusses past and present efforts to reform the civil service and - building on some of the findings from the earlier sections - highlights particular areas which could usefully be the focus of future reform. Section E concludes.

\section{B. Namibia's Civil Service and Wage Bill in International Comparison}

52. Namibia is expected to spend 14.7 percent of GDP on personnel costs in 2004/05, accounting for more than half of current expenditures and two-fifths of total spending. ${ }^{18}$ These numbers are very high by almost any standard. Of 44 African nations for which data

\footnotetext{
${ }^{17}$ Prepared by Koshy Mathai (FAD).
}

${ }^{18}$ Throughout this chapter, we will refer to cash wages and salaries along with cash allowances and other benefits. In-kind benefits (such as government housing, vehicles, and mobile phones) are typically not captured in government wage bill statistics, although they are, in many countries, a very important component of compensation. 
are available, ${ }^{19}$ only two have a central government wage bill that is larger relative to GDPand, in fact, only marginally so - than Namibia's (Figure III.1). Namibia's wage bill is more than twice the sample average (7.2 percent of GDP) and considerably more than twice the average for sub-Saharan Africa (6.1 percent of GDP). A similar picture emerges when considering wages relative to total spending, with Namibia placing fifth highest in the sample (Figure III.2). These findings are not explained by Namibia's position as one of the richest African nations: in fact, other middle-income countries worldwide have wage bills averaging only 8.5 percent of GDP, or 21.6 percent of total spending.

Figure III.1. Selected African Countries: Wage Bill (percent of GDP)

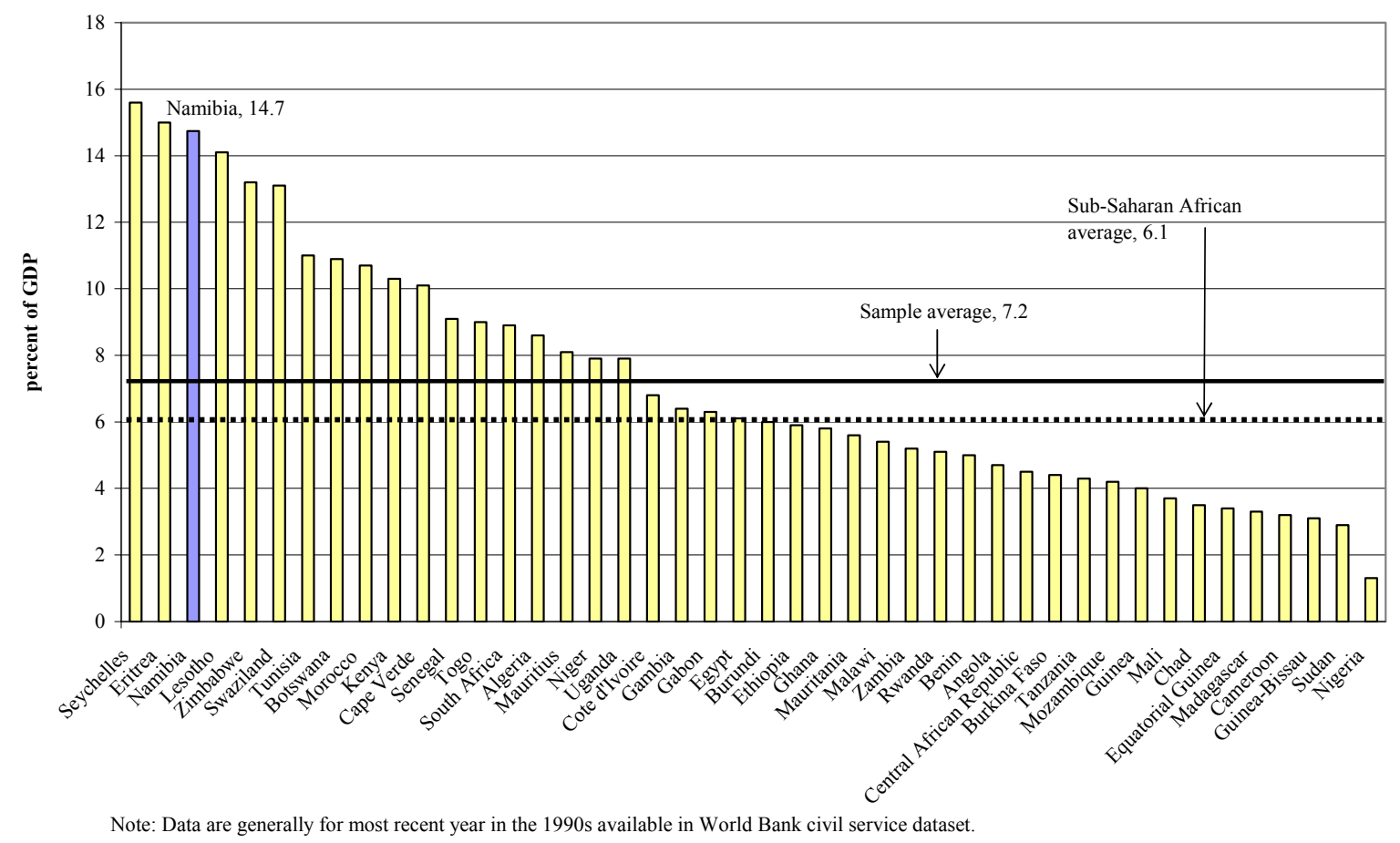

53. A country's wage bill is driven by two factors: the wages paid and the number of workers. Figure III.3 indicates that Namibia's high wage bill is not caused by overly high

${ }^{19}$ The international comparisons are based on a World Bank dataset from the website http://www1.worldbank.org/publicsector/civilservice/. Unless otherwise noted, the figures for Namibia relate to $2004 / 05$, while the cross-country data are for the most recent available year in the 1990s. The dataset has some coverage issues, and thus undue focus should be placed neither on any individual comparator's ranking under different measures, nor on cross-figure comparisons of rankings for particular countries. 
average wage levels. Indeed, while the ratio of the average government wage ${ }^{20}$ to GDP per capita is 4.8 for the typical country in sub-Saharan Africa, and 4.2 for the typical middleincome country, the ratio is only 3.4 in Namibia. ${ }^{21}$

Figure III.2. Selected African Countries: Wage Bill (percent of total expenditure)

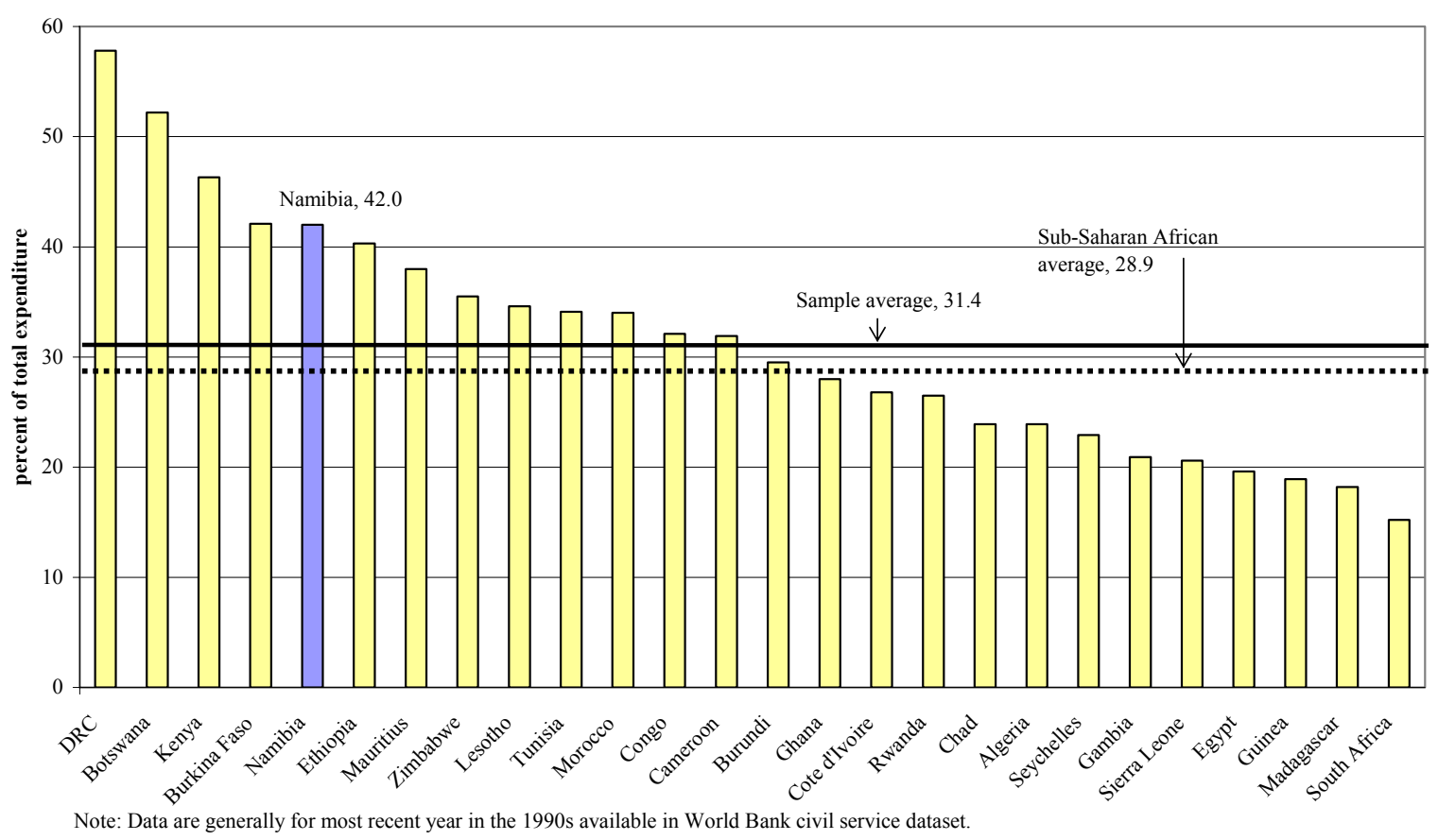

54. Rather, the problem appears to lie with the size of the civil service (Figure III.4). Central government employment (including the military) accounts for 4.3 percent of the population in Namibia, a higher percentage than in all but five other African nations for which data are available. By comparison, the average in the sample is only 2.1 percent, and the average for sub-Saharan Africa is even lower, at 1.6 percent of the population. It is often, and rightly, noted that cross-country comparisons like these are difficult, given

\footnotetext{
${ }^{20}$ The average government wage is constructed by dividing the government wage bill by the number of employees.
}

${ }^{21}$ These data alone do not imply that Namibian civil servants are underpaid: GDP per capita can be misleading when the income distribution is highly skewed. Section D below, however, presents additional information to argue that Namibian civil servants receive less than their private sector counterparts, particularly at the higher echelons, which may make it difficult to attract and retain talented staff. 
Figure III.3. Selected African Countries: Ratio of Average Government Wage to GDP Per Capita

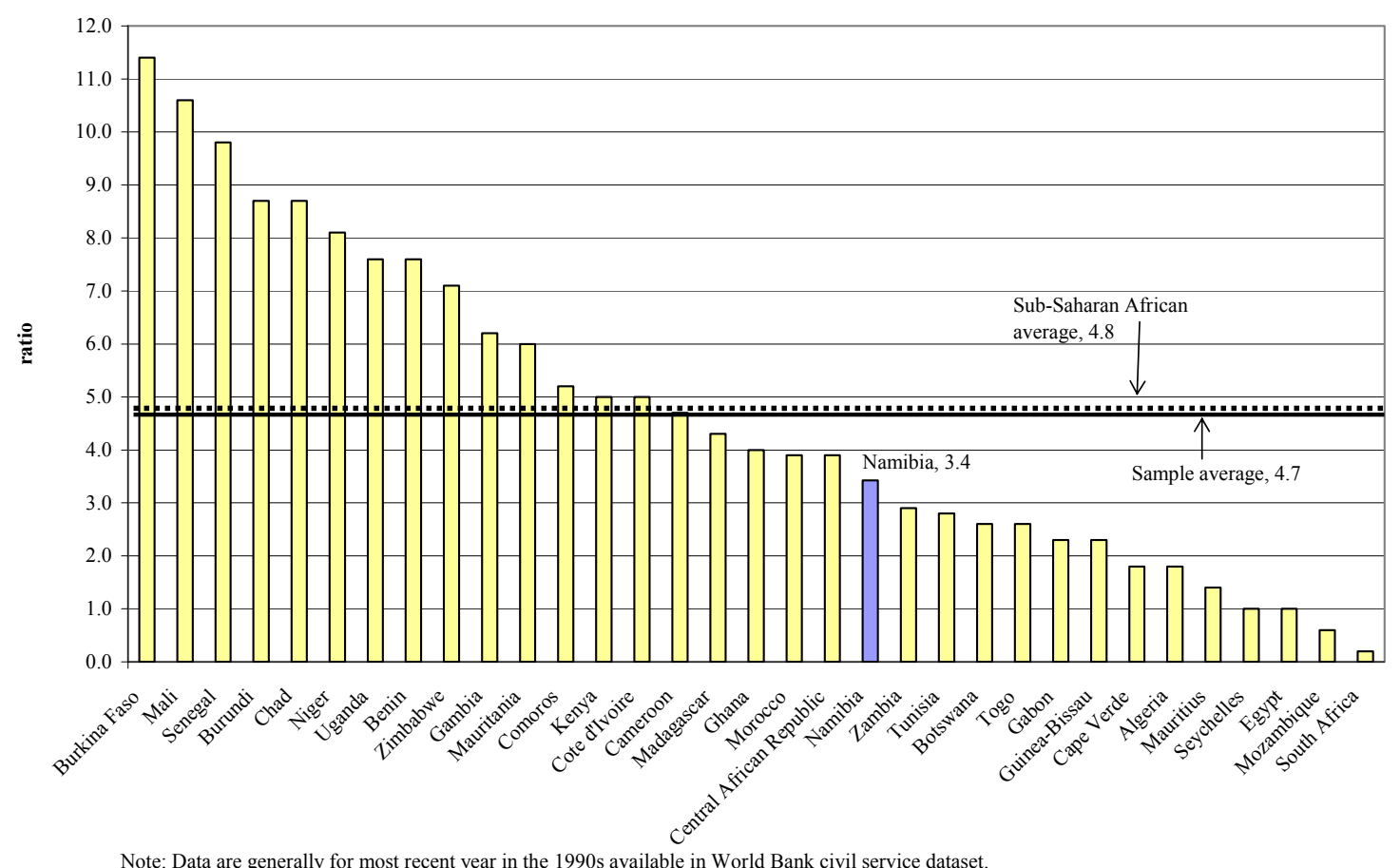

Figure III.4. Selected African Countries: Central Government Employment (percent of population)

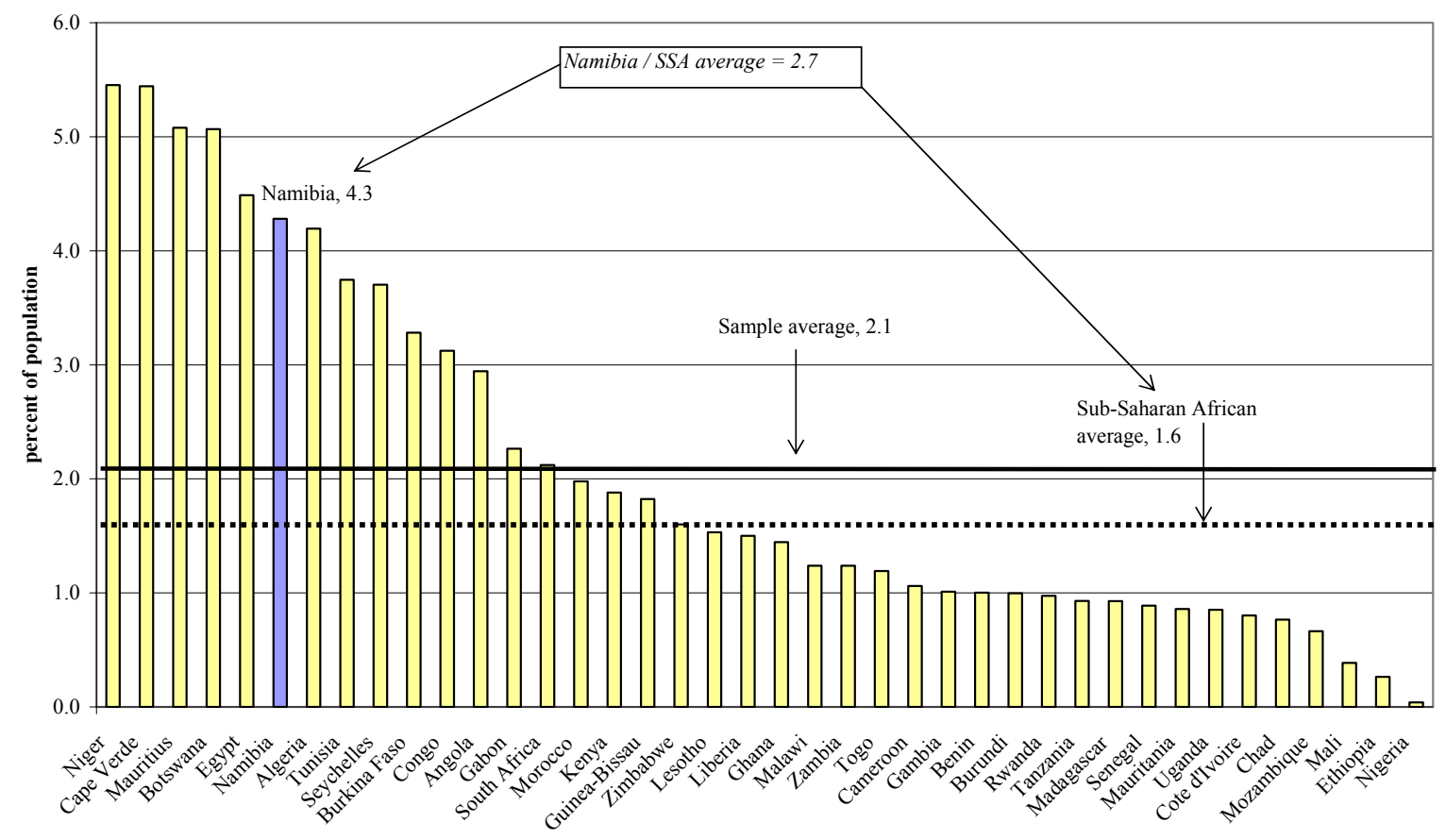

Note: Data are generally for most recent year in the 1990s available in World Bank civil service dataset. 
Figure III.5. Selected African Countries: Civil Service Wage Bill versus Employment

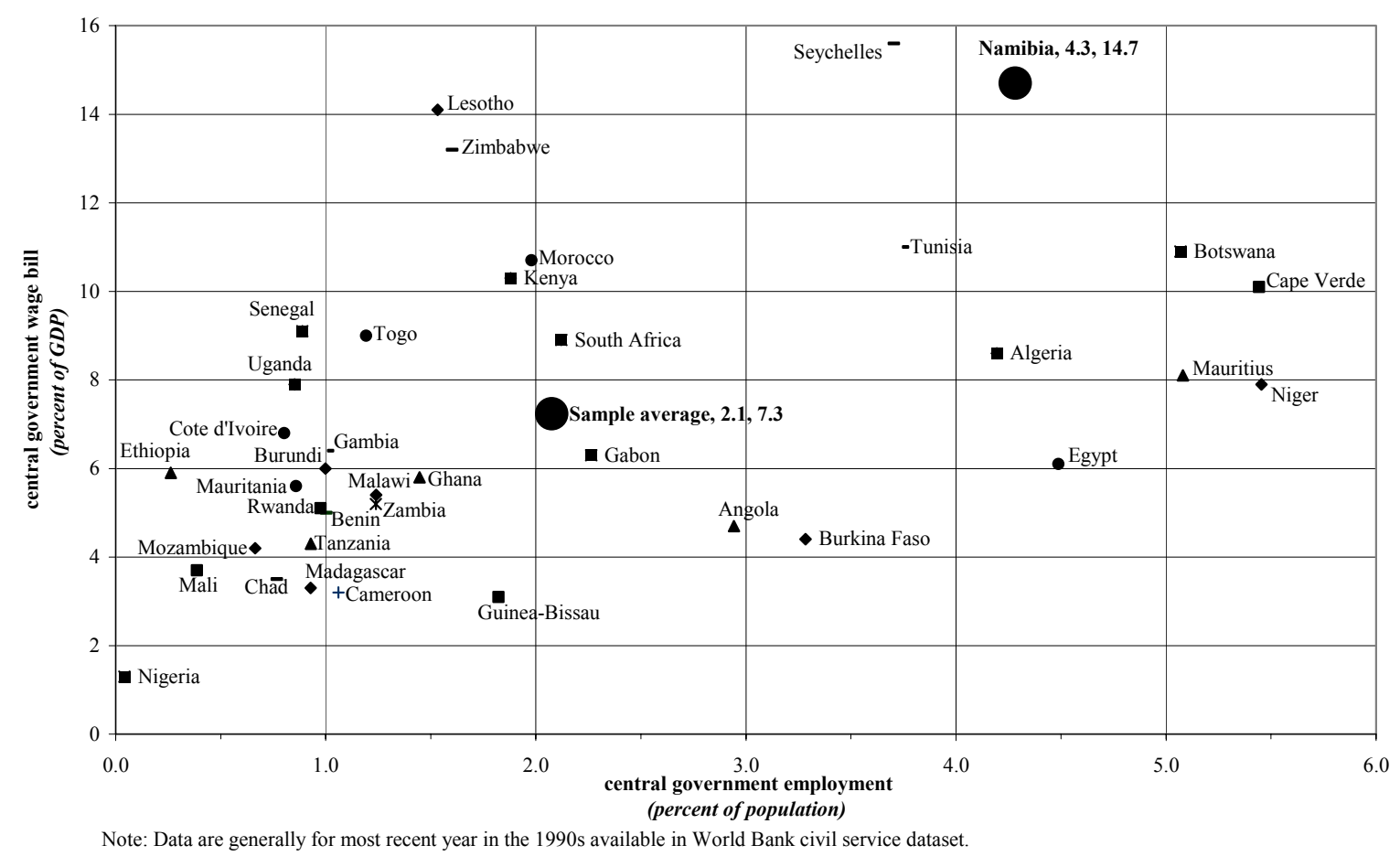

differing country conventions regarding the definition of the civil service; nonetheless, in light of the magnitudes involved, it seems safe to conclude that the Namibian government employs more people, relative to the population, than do the governments of other countries.

55. A summary scatter plot of the sample countries illustrates that Namibia has double the wage bill and double the civil service employment of the typical African country (Figure III.5). Relative to other regional and income groupings, Namibia's wage bill is higher than all comparators, and only high-income countries have civil services that are significantly larger, relative to the population, than Namibia's (Figure III.6).

56. The authorities note that Namibia has a very small population spread over a very large area of land, and that, under these circumstances, whatever economies of scale in public service provision may emerge in more densely populated countries are likely to be absent. This may be one explanation for why a relatively high proportion of the population is needed in the government. Indeed, if one considers the absolute number of civil service employees, without normalizing with respect to population, Namibia looks very ordinary: its 85,000 central government workers put it somewhat below the mean in the African sample.

57. Previous staff papers on Namibia have pointed out some historical and cultural factors that could explain Namibia's high civil-service-to-population ratio. In particular, at the time of independence in 1990, the job rights of incumbent civil servants were protected 
Figure III.6. Regional and Income-Group Averages: Civil Service Wage Bill versus Employment

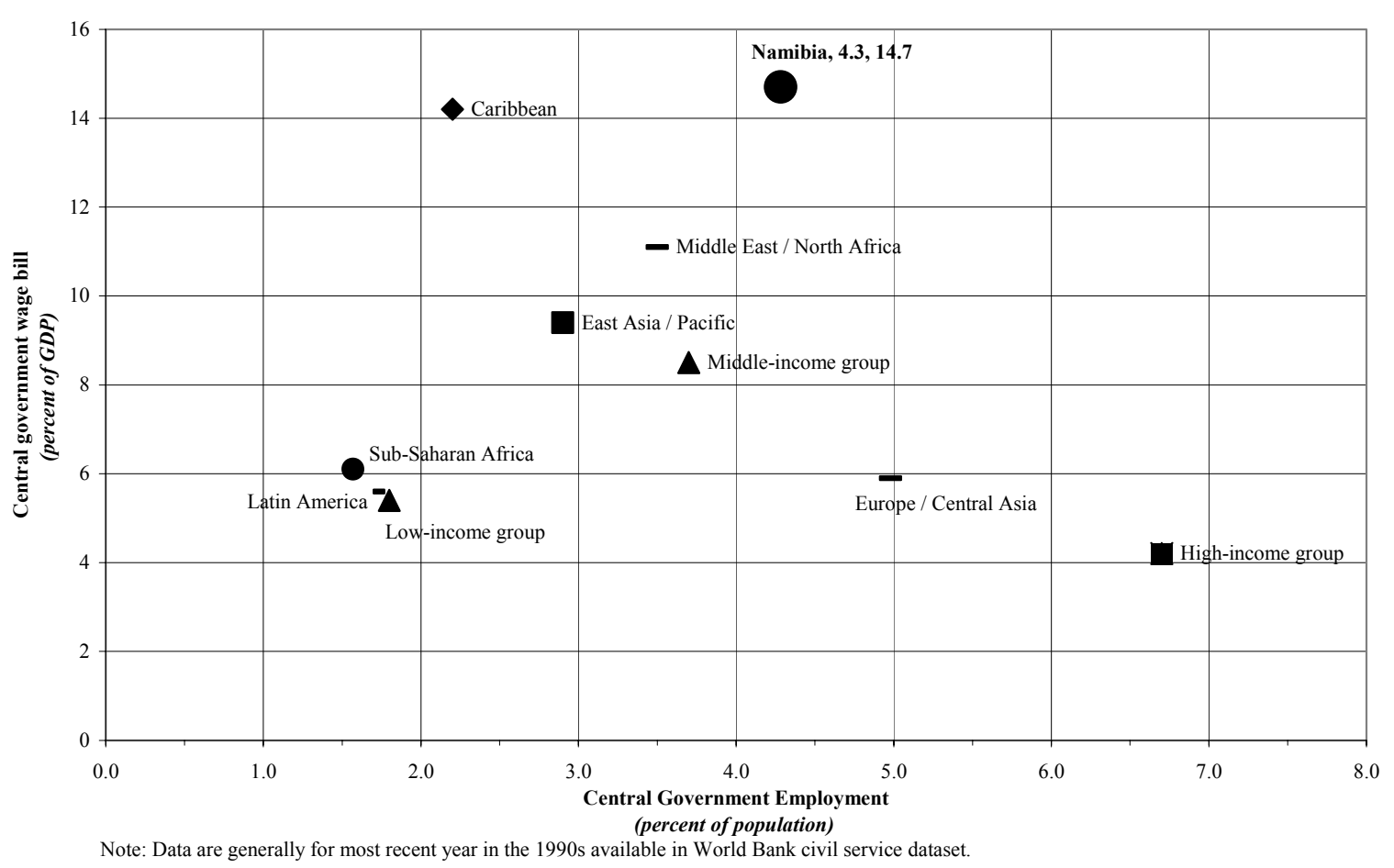

under the new constitution. In addition, the government hired large numbers of new employees, both to staff new functions (such as foreign affairs) and to benefit previously disadvantaged groups that had been excluded from the benefits of civil service employment under the apartheid regime. A number of "ex-combatants" (i.e., former freedom fighters from the independence movement) have also traditionally been employed in the civil service, but they appear to account for less than 2 percent of the total government wage bill in the 2004/05 budget.

58. The armed forces, however, constitute a significantly higher proportion of the population in Namibia than in other African countries (Figure III.7). The military-population ratio is, in fact, 2.5 times larger than in comparator nations. This may be explained by the armed conflicts in the region. Recall, however, from Figure III.4, that the ratio of all civil servants to the population was 2.7 times larger in Namibia than in the sample group. In other words, the large size of the Namibian defense establishment may be a reflection of the general overstaffing in the civil service, rather than a particularly acute sectoral problem. By contrast, Figure III.8 seems to suggest that there is an unusually large number of police officials in Namibia relative to the comparator countries. No firm conclusions are possible, however, without further analysis of the requirements for police services, the prevalence of crime, and other measures of expenditure efficiency. 
Figure III.7. Selected African Countries: Armed Forces (percent of population)
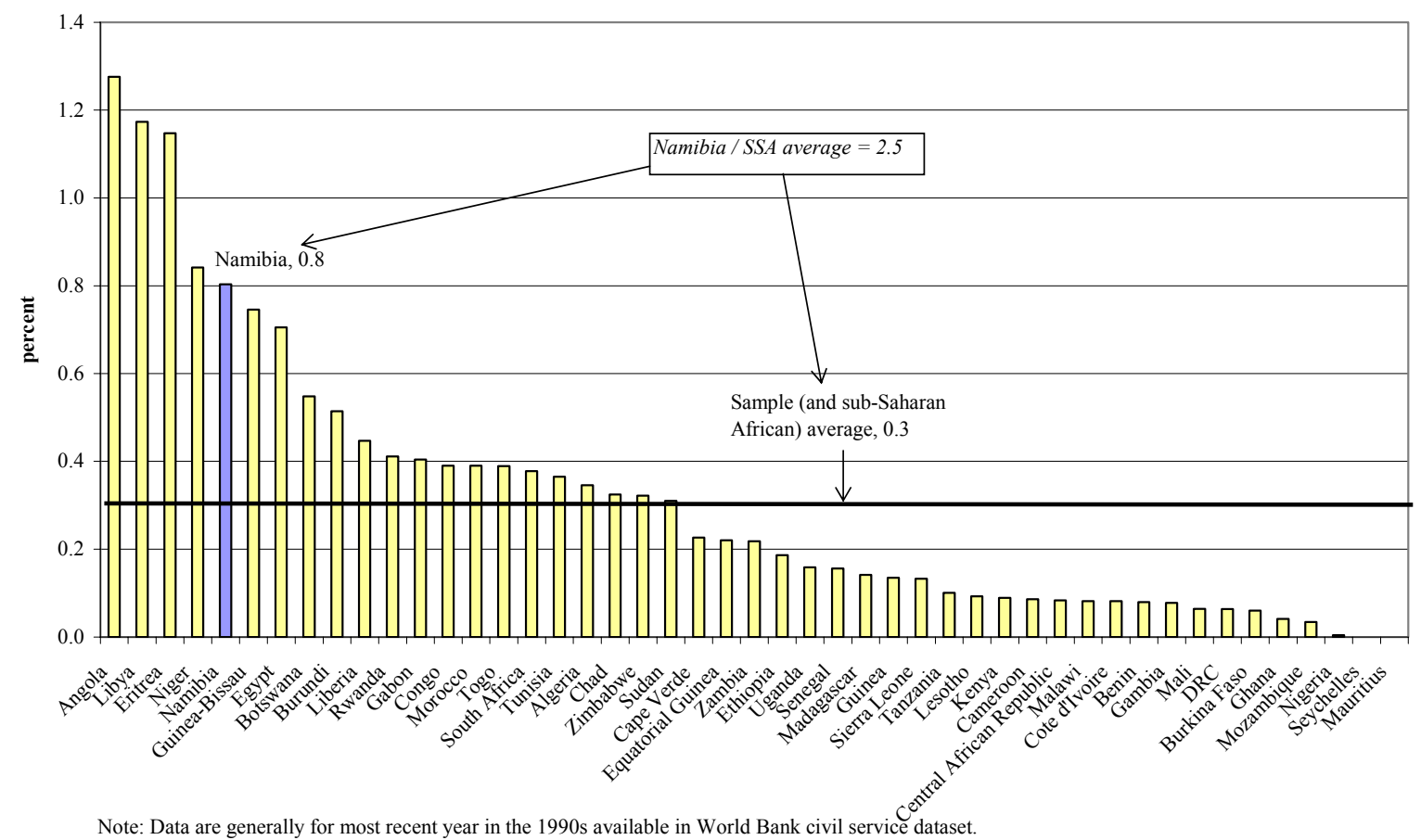

Figure III.8. Selected African Countries: Police (percent of population)

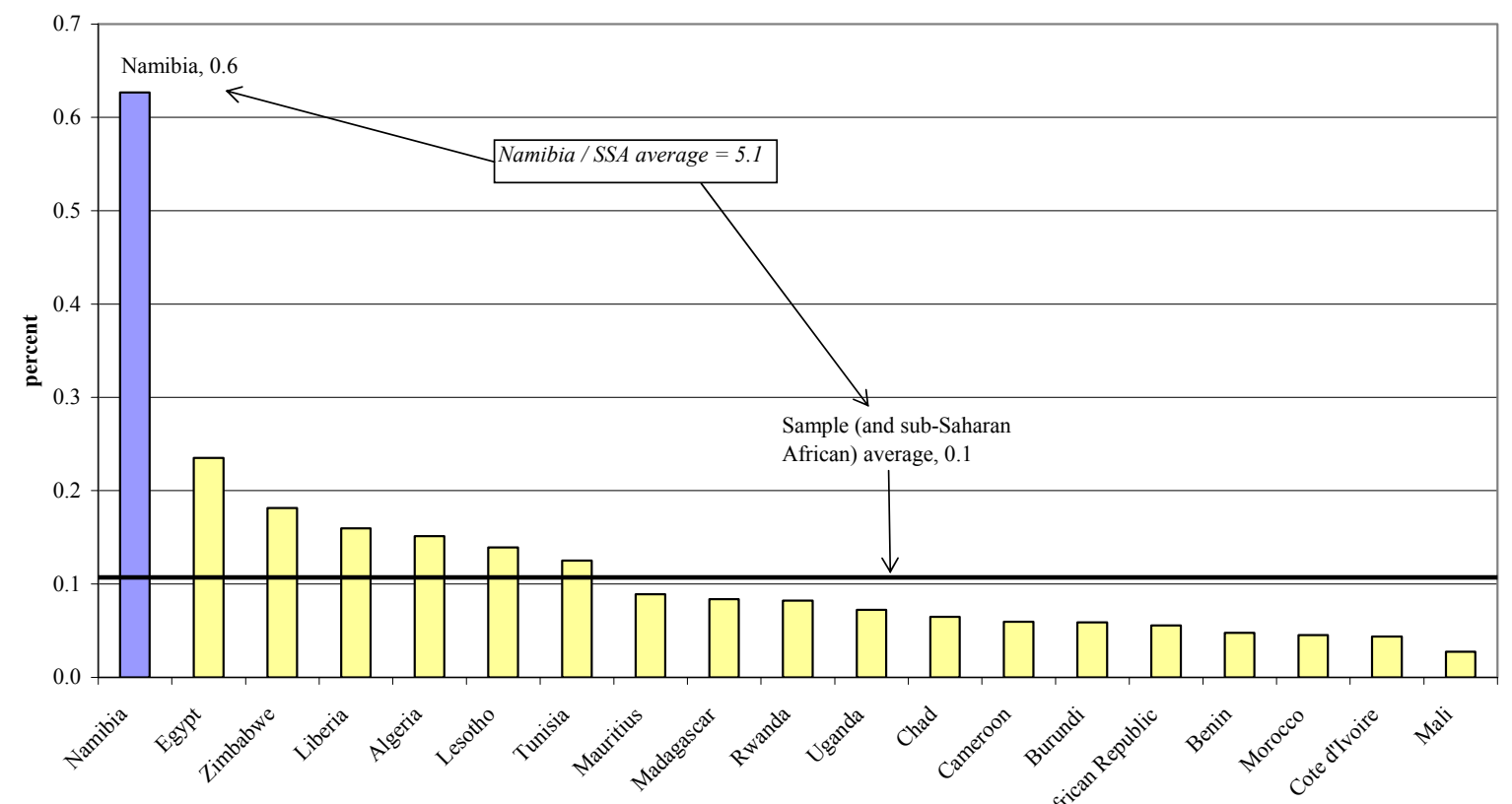

Note: Data are generally for most recent year in the 1990s available in World Bank civil service dataset. 
Figure III.9. Namibia: Central Government Wage Bill, 1995/96-2004/05

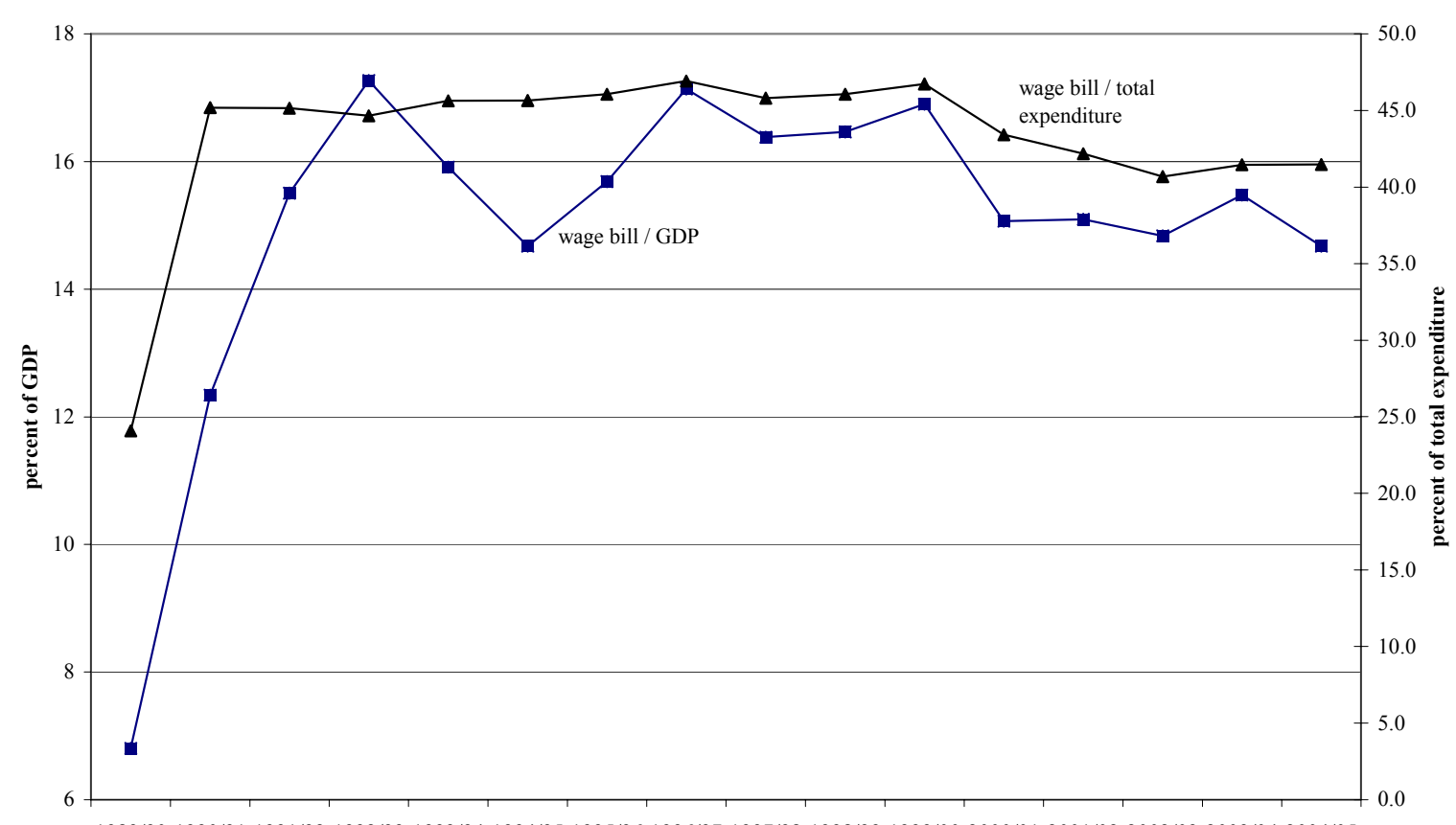

1989/90 1990/91 1991/92 1992/93 1993/94 1994/95 1995/96 1996/97 1997/98 1998/99 1999/00 2000/001 2004/05

\section{Analysis of Namibia's Civil Service and Wage Bill Over Time and Across Ministries}

59. The sharp growth in the civil service after independence was accompanied by a steep rise in the wage bill (Figure III.9). The wage bill rose from about 7 percent of GDP to 17 percent of GDP within the first three years after independence. Since then, however, the wage bill has slowly drifted downwards, reflecting various government efforts to control this spending.

60. The slow decline in the wage bill has occurred in spite of a continuous increase in staffing levels, as established, funded, and filled positions have all gradually trended upward during the past ten years (Figure III.10) ${ }^{22}$ In 2004/05, there were 85,000 filled posts in the civil service, including regional and local government employees (as they are on the central payrolls), as well as education, health, police, and military personnel. On average, between

${ }^{22}$ Similar to the arrangement in other countries, the Public Service Commission determines the "establishment"- the approved number of civil service posts. The Ministry of Finance may not choose to provide funds to finance all of these positions, and thus there may be fewer "funded positions" than "established positions." And, given rigidities in the formal process of hiring new civil servants, not all funded positions are always filled. 
Figure III.10. Namibia: Size of Civil Service, 1995/96-2004/05

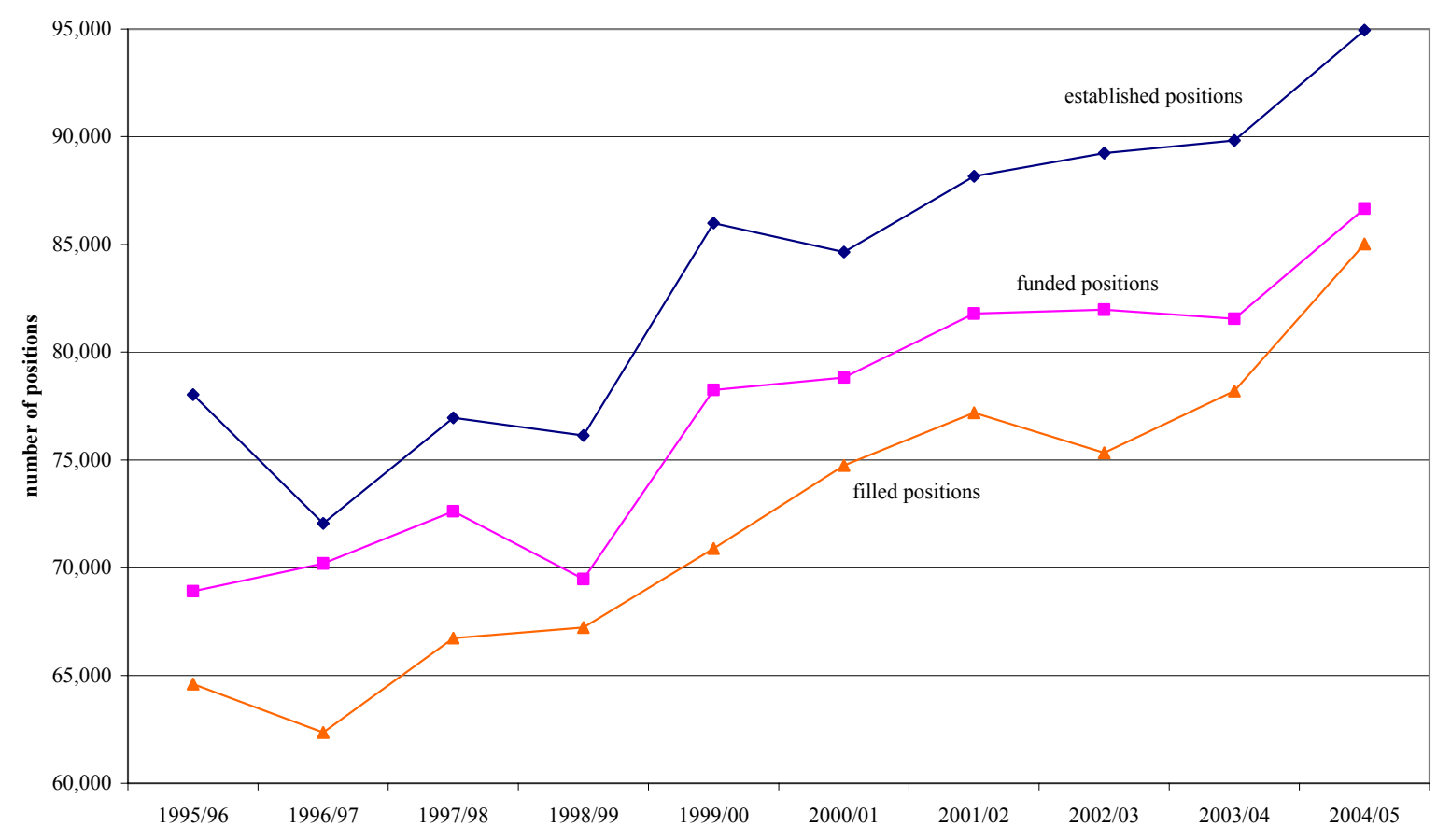

80 and 90 percent of established positions are filled at any given time; for 2004/05, the fill rate was about 90 percent for the government as a whole, with significant variation across ministries (Figure III.11). ${ }^{23} 24$

61. As in many other countries, teachers represent the bulk of Namibia's civil servants, although the share of civil service positions in the area of education has fallen from 39 percent to 36 percent during the last decade (Figure III.12). In the same vein, the share of the health sector has fallen by 3 percentage points during the period. This has been more than compensated by the increased shares of the ministries in charge of defense, police, and prisons, which have jointly risen from 19 percent to 35 percent. A similar picture emerges

${ }^{23}$ The figures refer to "votes," rather than ministries. A vote is a government unit that receives its own budgetary appropriation. Each ministry generally corresponds to one vote, although some of the larger ministries are represented by multiple votes.

${ }^{24}$ According to the law, the establishment is never supposed to be exceeded. Even in the case of short-term labor needs, the Public Service Commission has to authorize temporary expansions of the establishment. In practice, however, there are presumably exceptions to the rule, as indicated in Figure III.11. 
when assessing the shares of these ministries in total personnel expenditure (Figure III.13). ${ }^{25}$ However, in comparing Figures III.12 and III.13 it becomes evident that the defense, police, and prison employees are compensated at wages that are slightly below the average, as they account for a larger percentage of employment than of expenditure.

62. This finding is confirmed in Figure III.14, which computes the average compensation of workers, by dividing total personnel expenditure by the number of employees. Across the government, average compensation in the $2004 / 05$ budget (including pension contributions) amounts to N\$62,378, and thus 3.4 times per-capita GDP, as discussed above (Figure III.3).

Figure III.11. Namibia: Percent of Established Positions Filled, by Vote, 2004/05

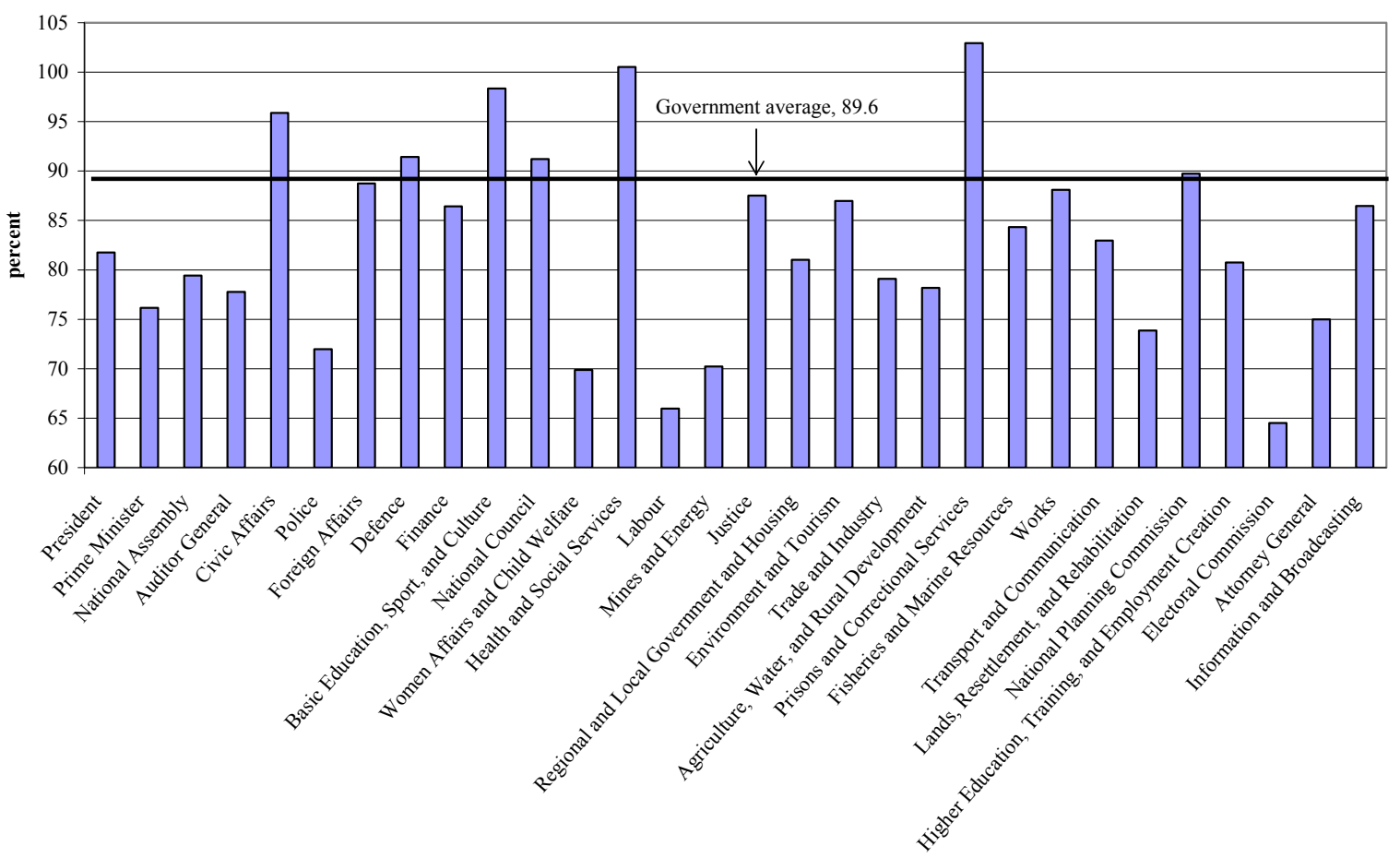

${ }^{25}$ This expenditure includes basic pay, cash allowances, and government pension contributions. In-kind benefits are excluded, as are travel expenses (e.g., per diems), which are regarded (as in most countries) as spending on goods and services. 
Figure III.12. Namibia: Filled Civil Service Positions, by Vote, 1995/96-2004/05

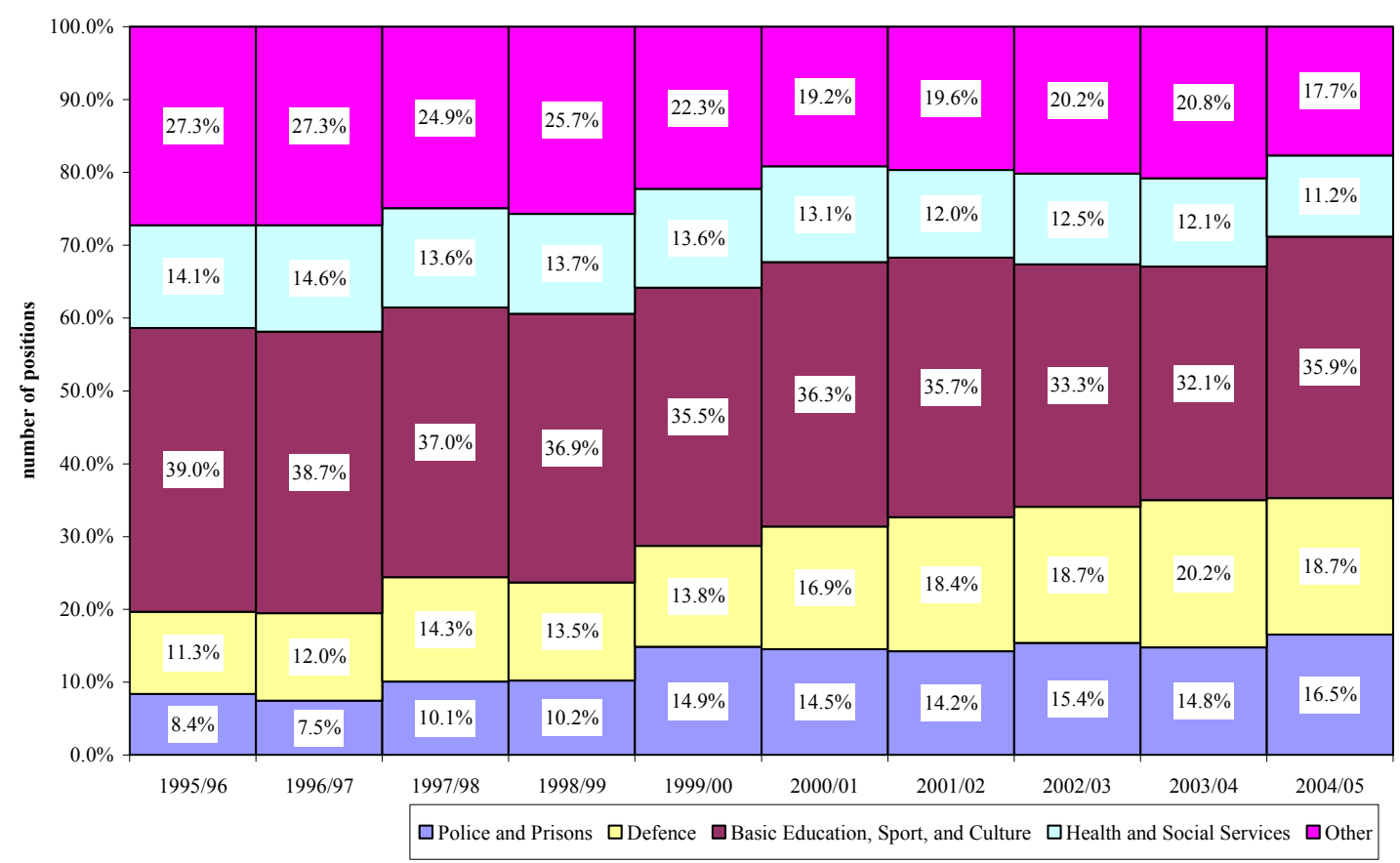

Figure III.13. Namibia: Shares of Total Personnel Expenditure, by Vote, 2004/05

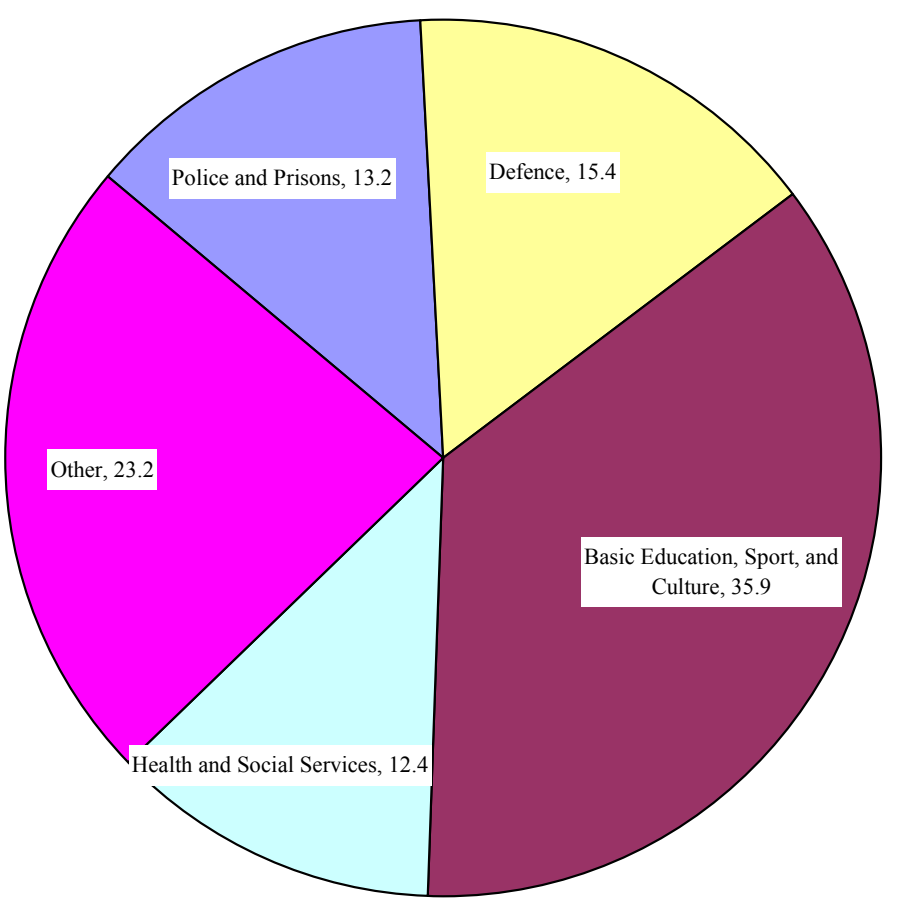

CInternational Monetary Fund. Not for Redistribution 
Figure III.14. Namibia: Average Compensation per Employee, by Vote, 2004/05

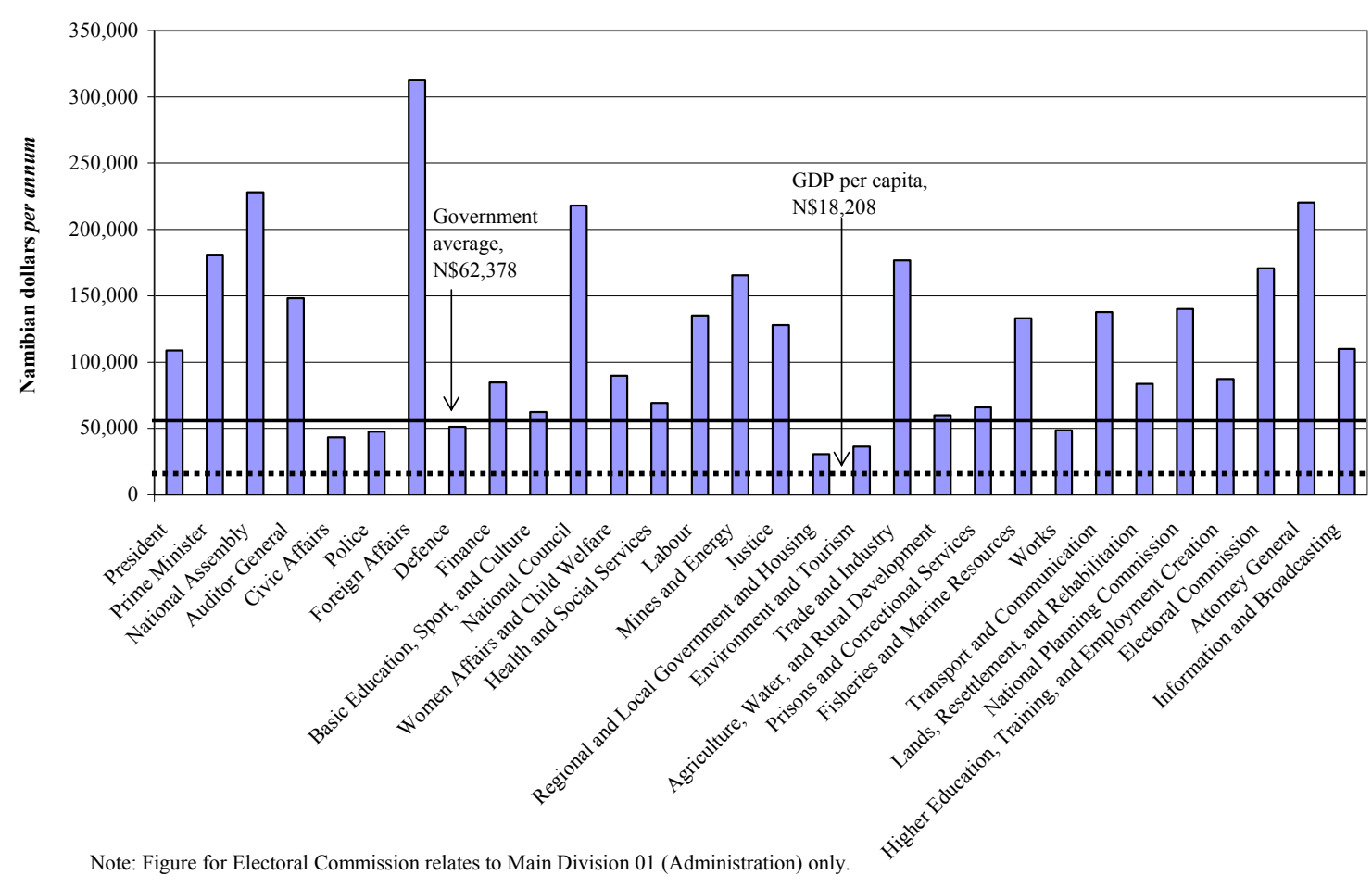

Underlying this average, however, there is a great deal of variation across votes. For instance, the employees of the Ministry of Regional and Local Government and Housing earn about N\$30,000 on average, while those in the Ministry of Foreign Affairs earn more than ten times this amount, perhaps reflecting extra allowances for foreign officers. It may also be true that much of the variation is due to compositional differences: the mix of skilled and unskilled, or managerial and line, employees differs greatly across government, depending on a particular unit's function.

63. About 86 percent of personnel expenditure is related to basic pay ("remuneration"), while government contributions to pensions account for 11 percent (Figure III.15). The remainder reflects cash benefits and allowances ("other conditions of service"). ${ }^{26}$ While in some African countries cash allowances form a major part of total pay and can sometimes exceed the value of basic pay, this is not the case in Namibia where such allowances account for only $3 \frac{1}{2}$ percent of monetary compensation, with some variation across ministries (Figure III.16). It should be noted that insufficient information is available for the prevalence of noncash benefits, which impairs somewhat an assessment of how streamlined the Namibian system of civil service compensation is overall.

${ }^{26}$ As noted earlier, these calculations exclude in-kind benefits altogether. 
Figure III.15. Namibia: Decomposition of Personnel Expenditure, 2004/05

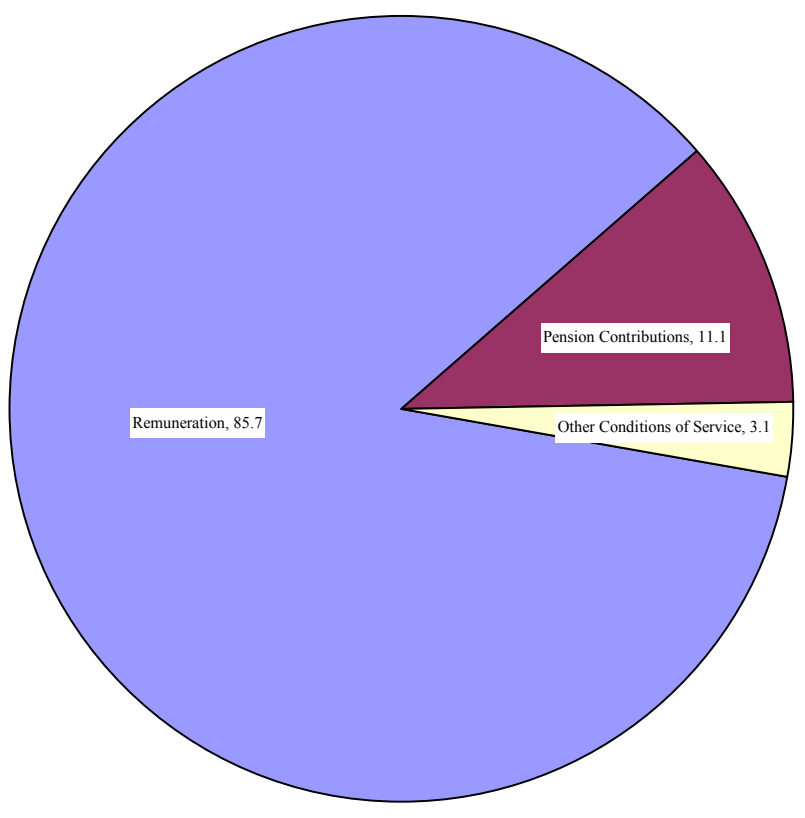

Figure III.16. Namibia: Cash Allowances as a Percent of Monetary Compensation, by Vote, 2004/05

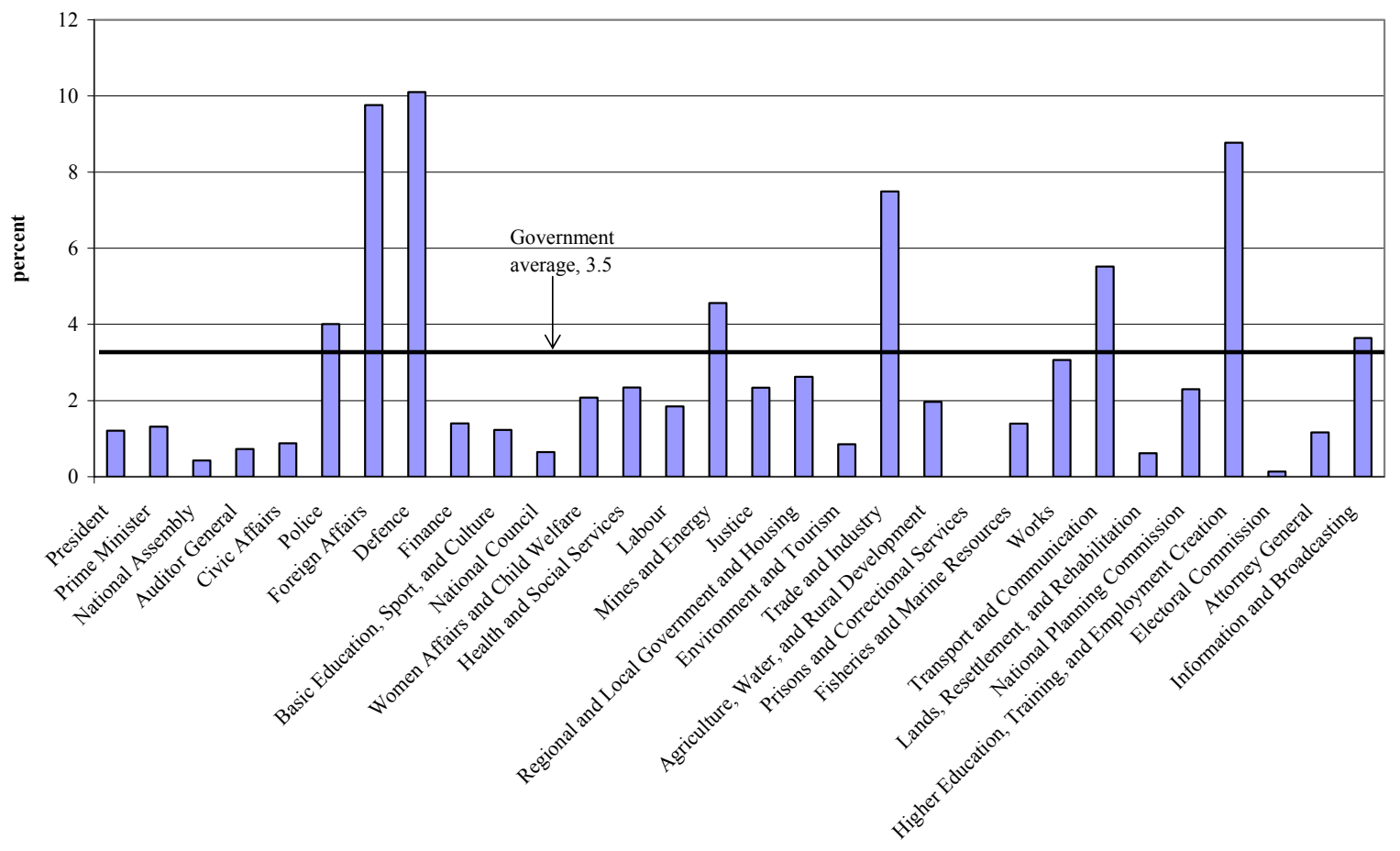




\section{Civil Service Reform Efforts: Past, Present, and Future}

64. The Namibian authorities have recognized that addressing the high wage bill is key to fiscal sustainability. As a result, and as discussed above, after an initial surge in the postindependence period, the wage bill has slowly drifted downwards. To some extent, this reflects repeated efforts to rein in the costs of the civil service.

65. In 1995, the Wages and Salary Commission (WASCOM) was formed and assigned to analyze the civil service and its compensation. WASCOM recommended a new and simplified set of payscales along with a system for annual performance reviews. It also recommended that (i) various benefits be rationalized (and certain allowances be folded into regular pay); (ii) government pension contributions be reduced; (iii) a civil service census be conducted; (iv) privatization and commercialization of public enterprises be undertaken; (v) the appropriation for personnel costs be reduced by 2 percent annually over five years; and (vi) labor laws be made more flexible. ${ }^{27}$ Many of these recommendations were adopted, but the wage bill has remained large, as the downsizing elements of WASCOM's recommendations were highly controversial. In fact, the civil service continued to grow after the WASCOM report was published (Figure III.10).

66. The authorities have recently taken additional steps to control the wage bill, including instituting a freeze on new hiring and reducing overtime pay and travel allowances. They share the view that the wage bill needs to be reduced but emphasize that civil service reform must have other, broader goals as well. This is in line with the standard approach to civil service reform. Box III.1 summarizes the World Bank's experience in this area and describes the measures typically incorporated in a civil service reform.

67. One of the major goals of civil service reform, aside from reducing employment and the wage bill, is to rationalize and decompress public payscales, so that the government is able to attract and keep talented staff. Text Table III.1, taken from the WASCOM report, shows that government wages in Namibia lag significantly behind those in the private sector, for many different types of jobs. However, such comparisons must be made carefully, as the World Bank also cautions. ${ }^{28}$ First, all benefits must be considered. For example, government teachers in Namibia are estimated to earn 8 percent less in salary, but 9 percent more in total compensation (including housing and medical insurance, etc.) than their private sector counterparts. Second, intangibles are important as well: job security, lower stress, and increased prestige may make government work more attractive and reduce the wages that need to be offered. Finally, it is not always appropriate to compare government wages against those in the formal private sector, as the alternative for many civil servants would be taking a job in the informal sector, where wages may be considerably lower.

${ }^{27}$ For more details, see Box 2 of Country Report No. 97/119.

${ }^{28}$ See http://www1.worldbank.org/publicsector/civilservice/ for more details. 
68. There exists some anecdotal evidence suggesting that public servants in Namibia receive less compensation than they would in the private sector, and especially so at the higher managerial levels. For example, the tax administration attributed weaknesses in its audit department at least partly to the poor pay auditors receive in the public sector, relative to the private sector. This points toward the need for a decompression of government wage scales so as to ensure that adequate talent is attracted.

\section{Box III.1. The World Bank and Civil Service Reform}

A World Bank evaluation report on civil service reform (Girishankar et al., 1999) recognizes "three stylized forms of bureaucratic dysfunction":

- "endemic overstaffing accompanied by unsustainable wage bills";

- "a combination of misaligned organizational structures, poor human resources, and inadequate incentives"; and

- diminished "credibility and accountability of state institutions" on account of "cumbersome civil service rules, political interference, and cultures of nonperformance."

In its civil service reform lending operations, the World Bank has traditionally focused on three types of measures:

- downsizing and introducing "hard budget constraints" on the wage bill;

- capacity building to allow governments to "do more with less"; and

- institutional reform measures to improve accountability and transparency.

The evaluation report found that the outcome of World Bank operations in the area of civil service reform has frequently fallen short of expectations and recommended several key measures for future operations:

- The primary objective (downsizing, capacity building, or institutional reform) should be identified, and performance indicators should be developed and standardized;

- Capacity-building interventions should be linked to job descriptions and monitorable performance of civil servants and their respective units;

- Reforms should be preceded by institutional assessments of administrative systems and analyses of labor market trends, in addition to budget scenarios; and

- The feasibility of "promoting results-based management" should be explored. 
Text Table III.1. Namibia: Public-Private Pay Differentials, 1995/96

\begin{tabular}{lccc}
\hline Position & $\begin{array}{c}\text { Government } \\
\text { (N\$ per annum) }\end{array}$ & $\begin{array}{c}\text { Private Sector } \\
\text { (N\$ per annum) }\end{array}$ & Percentage Differential \\
\hline Non-Management & & & \\
General Laborer & 5,517 & 7,536 & $36.6 \%$ \\
Record/Registry clerk & 12,522 & 16,212 & $29.5 \%$ \\
Data Typist & 13,023 & 19,968 & $53.3 \%$ \\
Technical Assistant & 16,542 & 23,208 & $40.3 \%$ \\
Personnel Officer & 36,607 & 43,086 & $17.7 \%$ \\
Accountant & 36,607 & 47,682 & $30.3 \%$ \\
Research Technician & 37,526 & 45,522 & $21.3 \%$ \\
Engineer & 61,056 & 74,160 & $21.5 \%$ \\
& & & \\
Management & & & $40.5 \%$ \\
Deputy Director & 73,455 & 103,169 & $52.8 \%$ \\
Director & 86,433 & 132,067 & $59.1 \%$ \\
Under Secretary & 101,148 & 160,933 & $77.6 \%$ \\
Deputy Secretary & 104,091 & 184,896 & $108.2 \%$ \\
Permanent Secretary & 111,264 & 231,609 & \\
\hline
\end{tabular}

Source: Namibia WASCOM report.

69. Attracting and retaining talented civil servants would be consistent with other reform efforts in the civil service aimed at improving public service delivery. Various initiativesincluding a public servant handbook, a charter process, "e-governance," improved automation, a civil service college, and the Performance and Effectiveness Management Program (PEMP) - have recently been introduced in response to this need. These initiatives tie into Vision 2030 and other medium- and long-term planning instruments.

70. Nevertheless, a clear vision for the adequate structure and remuneration of the civil service over the medium to long term is still lacking. Preliminary thoughts aim at linking staffing allocations to the priorities identified under the new output-based budgeting system. Similarly, consideration is being given to develop sector-specific staffing strategies.

Additional momentum could be gained by making rules on the redeployment of staff from one government unit to another more flexible and introducing a real-time monitoring system of staffing levels (including temporary workers). In addition, and perhaps most important of all, it would seem essential that the authorities develop a medium-term plan to downsize the civil service. 
71. The recent decision to freeze hiring is a good sign of the authorities' commitment to address pressing macrofiscal concerns. It represents a first step toward managing the size of the public sector: if new employees are not hired, while current staff continue to leave employment (through resignation, retirement, or death), a natural process of attrition will take hold. This rate of attrition, however, may be slower than the authorities require, given the need to generate budgetary savings. Moreover, the reductions may not occur in those segments of the civil service which the authorities would optimally downsize. A hiring freeze could also create substantial problems, as it may affect the government' ability to function. For instance, the Inland Revenue Department currently cannot hire additional auditors although an internal study has revealed that each additional dollar spent on audit could yield up to twelve dollars in revenue. Against this background, a hiring freeze can only be considered a stop-gap measure that cannot substitute for a properly designed medium-term employment strategy.

72. Outright layoffs, especially at a large scale, would probably be neither desirable nor feasible. As the authorities note, employment opportunities in Namibia are scarce, and the government has traditionally played a social role in providing jobs. Although this may not be the most efficient mode of assistance - targeted grants and subsidies may be more appropriate-layoffs would likely cause major social and political difficulties. In addition, civil servants have legal protections that may make involuntary layoffs impossible. Nevertheless, studying staffing needs of the various ministries and reallocating staff accordingly, eliminating possibly redundant government agencies, and implementing some targeted measures to accelerate the departure of some civil servants, may all be necessary to effect a sustained reduction in the wage bill. In this process, it is important to ensure that the targeted outputs of government services can be delivered.

73. As noted by Rama (1999), countries frequently choose to offer severance packages to induce voluntary retirements. These packages, however, are often poorly designed and end up being more generous than necessary. Moreover, severance packages are usually accepted by the most talented civil servants - those the government would like to retain - given that they are the ones with the best job options outside the government sector. Designing a system to avoid this adverse selection can be difficult in practice. Many countries have suffered from what Rama calls the "revolving door," by which talented workers are retrenched and have to be rehired later so that the government can function: in such cases, the severance packages are wasted. It is also important to note that downsizing the civil service may not help the fiscal situation in the short term: not only may severance packages be needed, but laid-off workers will also likely require additional safety-net protection from the government.

\section{E. Conclusions}

74. The Namibian authorities have recognized that the size of the wage bill limits budgetary flexibility at a time when revenues are likely to decline and new spending needs are emerging. They have adopted various strategies to contain the wage bill, including relying on multi-year wage settlements and trying to constrain wage increments to less than inflation. 
75. Nevertheless, in light of the considerable fiscal challenges ahead, the authorities may want to consider developing a more determined strategy to address the key problem underlying the large wage bill: the size of the civil service. Efforts to reduce the civil service, which need to be well planned and prepared, could also allow the decompression of wage scales and increased remuneration for senior officials, who are undercompensated relative to the private sector. Such efforts, together with ongoing reforms to enhance public service delivery, should provide Namibia with a modern and efficient civil service.

\section{References}

Girishankar, Navin, et al. (1999), “Civil Service Reform: A Review of World Bank Assistance," OED Report No. 19599. [Available at http://www1.worldbank.org/publicsector/civilservice/evaluationofdonor.htm.]

Government of the Republic of Namibia (2004), Estimate of Revenue and Expenditure for the Financial Year 1 April 2004 - 31 March 2005.

International Monetary Fund (1997), "Namibia: Recent Economic Developments," Country Report No. 97/119.

Rama, Martin (1999), "Public Sector Downsizing: An Introduction," World Bank Economic Review, Vol. 13, No. 1.

Wages and Salary Commission Report (1995).World Bank, http://www1.worldbank.org/publicsector/civilservice/ 


\section{INTERNATIONAL RESERVES AND INVESTMENT DECISIONS BY INSTITUTIONAL INVESTORS $^{29}$}

\section{A. Introduction}

76. Investment decisions by Namibian institutional investors have had a major impact on Namibia's capital account and the level of international reserves over the last few years. This reflects the limited state of development of Namibia's financial markets and the broader range of investment opportunities available in South Africa's financial markets. Given the size of the assets under management (AUM) of insurance companies and pension fundsthey exceeded 100 percent of GDP in 2003 - the resulting impact on Namibia's capital account and reserves has been very pronounced. A recent study by the Ministry of Finance and the Bank of Namibia (BoN) concluded that such outflows amounted to N\$1.8 billion on average between 1990 and 1994 and surged to N\$2.3 billion annually between 1995 and 2000 (i.e., about 10 percent of GDP, annually). ${ }^{30}$ This trend has continued unabated.

77. This has prompted the Namibian authorities to consider options to keep a larger share of the national savings within Namibia's borders, with a view to channeling these funds to worthwhile domestic investment opportunities and, ultimately, enhancing the country's longterm growth potential. One part of the strategy has been to tighten investment guidelines, requiring a larger share of investment in domestic assets by institutional investors. Another part rests on the assumption that strengthening domestic capital markets will result in absorbing higher levels of Namibian savings within the economy.

78. This chapter is intended to provide an overview of the size and development of Namibia's institutional investors and financial markets (Section B), explain the major factors that have contributed to capital outflows to South Africa (Section C), and lay out some options that could help strengthen domestic financial markets and contain capital outflows (Section D). The chapter concludes that since domestic capital markets are in their nascency, the Namibian authorities should support their development through targeted policy actions. Nevertheless, since capital markets take time to develop, it can be expected that Namibia's capital account and reserves will continue to remain under pressure in the foreseeable future.

\section{B. Namibia's Financial Sector}

79. Namibia's financial sector comprises a relatively sophisticated banking system, a strong presence of pension funds and insurance companies, and capital markets that are still

\footnotetext{
${ }^{29}$ Prepared by Manmohan Singh (ICM). This paper has benefited from extensive discussions with Bank of Namibia officials, especially Paul Hartmann, Ipumbu Shiimi, and Phillip Shiimi. The views of the major banks and asset managers were also solicited.

${ }^{30}$ Media Release from the Cabinet of Ministers, July 27, 2004.
} 
at their early state of development (Text Table IV.1). As a result, much of the financial intermediation in Namibia takes place through the banking system, whereas nonbank financial institutions - in spite of their size - have so far only played a limited role in this area and invested most of their funds in South Africa. This has made Namibia a net exporter of capital to South Africa's financial markets, helped by the open capital account under the Common Monetary Agreement (CMA).

Text Table IV.1. Namibia: Structure of Financial System, End-2003

\begin{tabular}{lrr}
\hline & $\begin{array}{c}\text { In billions of } \\
\text { Namibia dollars }\end{array}$ & $\begin{array}{r}\text { In percent } \\
\text { of GDP }\end{array}$ \\
\hline Commercial banks & 20.0 & 61.9 \\
Nonbank financial institutions & 32.5 & 100.6 \\
Pension funds & 19.5 & 60.4 \\
Insurance companies & 13.0 & 40.2 \\
Bond market & 10.1 & 31.3 \\
Of which: government & 8.6 & 26.6 \\
Stock market capitalization & & 6.8 \\
Excluding dual listed companies & 2.2 & $1,779.7$ \\
Including dual listed companies & 575.0 & \\
\hline
\end{tabular}

Sources: Namibia Stock Exchange; NAMFISA; and staff estimates.

80. The foundation for the current features of Namibia's financial system was laid in the preindependence period. Its commercial banks were either controlled by South African parents or had strong ties with South Africa. ${ }^{31}$ While Namibia was still a protectorate of South Africa, its pension funds and insurance companies benefited from the strong emphasis of mining companies on creating adequate protection and securing retirement income for their

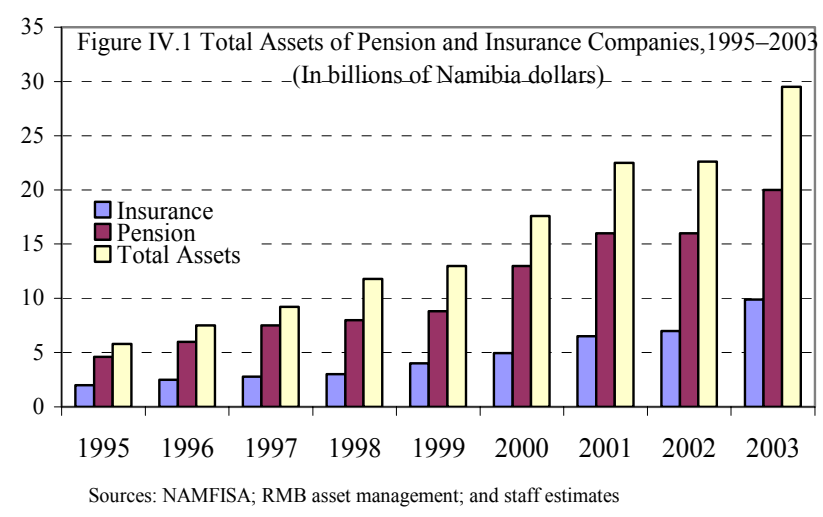

${ }^{31}$ See An Overview of the Namibian Bond Market, Bank of Namibia Annual Symposium, August 2004. 
employees. Since independence, this emphasis has broadened to other private companies, and the strong growth of the civil service has provided additional impetus to the rapidly expanding role of pension funds and insurance companies. As a result, by 1995 institutional investors had amassed some $\mathrm{N} \$ 5$ billion in AUM, or over 40 percent of GDP. This trend has continued in the past decade.

81. Namibia's capital markets are dominated by the government as the main issuer of debt instruments. The total domestic debt outstanding amounted to about $\mathrm{N} \$ 11.7$ billion at the endSeptember 2004, almost nine-tenth of which consisted of government debt. ${ }^{32}$ Since 2002, there has been a determined effort by the government
Figure IV.2. Total Government Debt Outstanding, 1995-2004 1/ (In millions of Namibia dollars)

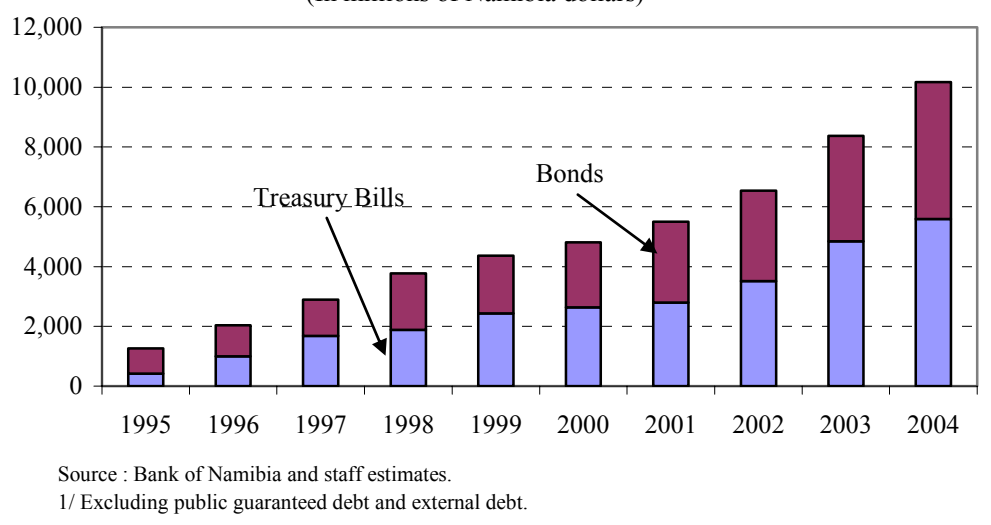

to cater to the interest of institutional investors in longer-term maturities and create a benchmark for the emergence of private debt instruments that could help finance longer-term investment projects. In fact, the government has successfully lengthened the maturity profile of its outstanding debt. However, the ratio of Treasury bills to the Internal Registered Stocks (i.e., the medium- and long-term bonds) has remained broadly the same. At present, there are five large issues outstanding, with maturities ranging from 2007 to $2024 .{ }^{33}$ The pension and insurance companies hold the bulk of the outstanding stock of government debt.

82. Parastatals account for much of the issues of non-government bonds, with an outstanding stock of over N\$700 million at end-June 2004. Parastatals began to tap the market in 1996, but only recently became major issuers. ${ }^{34}$ Issuance by parastatals is often

${ }^{32}$ Overall government debt amounted to N\$10.2 billion (31 percent of GDP) at the end of the 2003/04 fiscal year, of which N\$1.6 billion were external debt (5 percent of GDP). The public debt stock including publicly guaranteed debt amounted to $\mathrm{N} \$ 13.6$ billion (41 percent of GDP). Namibia's public debt stock is low by sub-Saharan African standards, but higher than in neighboring countries, such as Botswana and South Africa (with public debt/GDP ratios of 8 percent and 23 percent, respectively).

${ }^{33}$ The 2005 issue due in April 2005 has largely been rolled over via multiple "switchauctions" into other longer-dated issues; amortization due in April 2005 is now only about N\$300 million.

${ }^{34}$ Until 2002, the total outstanding stock of nongovernmental debt was below N\$200 million. 
guaranteed by the government and may have quasi-fiscal implications. The primary issuers in this category are the Road Fund Administration, Agriculture Bank, and National Housing Enterprise. Lately, some private issuers, such as Standard Bank and Bank Windhoek, have entered the market as well, but their market share is still small, with an outstanding stock of less than N\$1 billion.

83. Market capitalization at the Namibia Stock Exchange (NSX) largely reflects duallisted companies. Over 99 percent of the market capitalization is related to companies that are South African in origin and also quoted at the Johannesburg Stock Exchange (JSX). Although the dual-listed companies have business operations in Namibia, their listing on the NSX allows Namibian institutional investors to invest at least 35 percent of their AUM in "domestic assets" - a regulatory requirement intended to curb capital outflows, which has been behind much of the growth of the NSX. About eight companies account for over 90 percent of the market capitalization of dual-listed companies (Anglo-American, Standard Bank, Old Mutual, First Rand, Sanlam, Baloworld, Edgars, and JD Group). Pension funds and insurance companies have about N\$2 billion invested in the local equity market.

\section{Major Factors Behind Capital Outflows to South Africa}

84. Overall, the limited investment opportunities in domestic financial markets have led to sizable outflows of Namibian savings into the liquid and relatively developed markets in neighboring South Africa. These outflows have been at least double the level of inflows into Namibia reflecting the borrowing from Namibian banks from their South African parents to finance local credit operations. As a result, Namibia has increasingly large net claims on its neighbor, putting pressure on its capital account and its reserves levels.

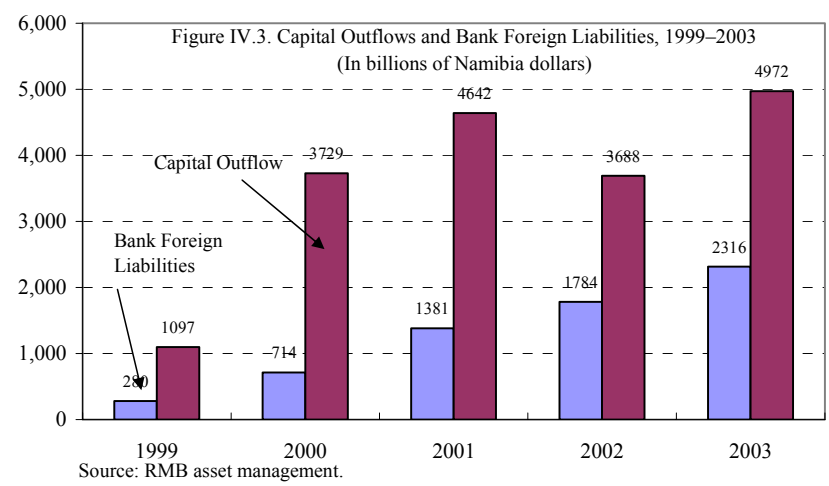

85. The AUM of Namibian pension funds and insurance companies are sizeable and, at more than 100 percent of GDP, one of the highest among emerging market economies. For example in Chile, a pioneer in this area, pension funds and insurers hold AUM equivalent to about 74 percent of GDP; in Argentina, this ratio is 16 percent; in Mexico and Poland, about 10 percent; in Malaysia, 77 percent; in Singapore, 103 percent; and in South Africa, 88 percent. Namibia's AUM with pension funds and insurers are almost three times as large as Namibia's domestic debt and equity markets (excluding dual-listed companies).

\section{Developing Domestic Financial Markets}

86. The earlier versions of Regulation 28 (for the pension fund industry) and Regulation 15 (for the insurance sector) had a regulatory requirement to hold a minimum of 10 percent 
of AUM in domestic assets. However, in the mid-1990s, the minimum threshold was raised to 35 percent, which contributed towards the growth in the NSX due to the increase in duallistings of South African companies. Since investments in dual-listed companies were unable to contain capital outflows, the government has recently proposed a further tightening of domestic asset requirements and other regulatory changes. However, these proposals, which are still subject to discussion with market participants before a decision on them is taken, may not have the intended results.

87. In addition, the authorities have acknowledged that regulatory changes alone may be insufficient in arresting capital outflows. Consequently, they are interested in developing domestic financial markets to provide institutional investors with assets denominated in Namibian dollars and increase domestic financial intermediation.

\section{Proposed regulatory changes and implications}

88. NAMFISA, the official regulator for nonbank financial institutions, is presently analyzing proposed amendments to Regulation 28 and Regulation $15 .^{35}$ A cabinet resolution suggests the following changes to the regulatory framework:

- All institutional investors to invest a minimum of 5 percent of their assets in unlisted Namibian companies.

- $\quad$ Reduce investment by institutional investors in dual-listed shares from 35 percent to 10 percent of their total assets over the next five years.

- Withdraw the tax free status of Unit Trusts and apply the afore-mentioned domestic asset requirement to Unit Trusts. ${ }^{36}$

89. Further analysis is required to ascertain that the amendments to Regulations 28 and 15 will have the intended results. Although market views are mixed, the 5 percent investment requirement in unlisted Namibian companies seems to be the most promising in attracting funds currently invested in South Africa, provided, however, that there are profitable and qualitatively sound investment opportunities in such unlisted companies. Some institutional investors have already invested small amounts in local projects, with mixed results. As a consequence, minimum requirements for investments in unlisted assets and onerous limits on the choice of investments may negatively affect the risk return profile of pension funds and insurance companies. This could run counter to the objective of safeguarding the financial

\footnotetext{
${ }^{35}$ Namibia Financial Institutions Supervisory Authority (NAMFISA) is the official regulator for the nonbanking sector and oversees the pension and insurance sectors, unit trusts and the stock exchange.

${ }^{36}$ Unit Trusts are regulated by the United Trust Control Act and are not governed by Regulation 28 or Regulation 15.
} 
soundness of the institutional investors and, ultimately, put at risk the savings and pensions of the population. This may make it advisable to move carefully on the broadening of options for investment in unlisted companies.

90. Furthermore, it is not clear if reducing the limit on investments in dual-listed companies from 35 percent to 10 percent will be a positive move. It may restrict capital outflows, but there is a real possibility that dual-listed companies may de-list from the NSX, as the demand for such shares could be reduced sharply. As market capitalization would diminish, the question of even having a stock exchange could arise.

91. Investment income from Unit Trusts is currently exempted from taxation. As a result of their tax-free status, Unit Trusts have become very popular over the past few years and attracted significant deposits from individuals previously held with commercial banks. Removing their tax-free status could lessen their importance and lead to withdrawals, with a concomitant strengthening of the deposit base of commercial banks.

\section{Issues to consider in building a domestic debt market}

92. International experience suggests that establishing benchmarks, improving the market infrastructure, and diversifying the investor base all contribute towards developing the domestic debt market. Furthermore, the standard codes of best practice would include, among other things, a credit environment backed by rating agencies.

93. Government bonds are traditionally seen as conducive to creating a benchmark for the emergence of other domestic debt instruments. The successful lengthening of the maturity profile of Namibian government bonds and the recent issues of bonds by parastatals and private issuers have already increased the attractiveness of the Namibian bond market, but further efforts are needed.

94. A presence in international markets could be conducive to broadening the investor base and inducing the emergence of new borrowers, which would provide an additional impetus to the development of domestic financial markets. The first step in this direction would be to obtain a sovereign rating. The Namibian authorities are contemplating seeking such a rating and possibly issuing a Eurobond, which has, as a side effect, the potential of lowering borrowing costs to the government (Box IV.1). Having a direct measure of sovereign risk is likely to raise the profile of Namibia as a place to invest and help attract foreign direct investment and other project finance flows to Namibia (such as for the Kudu offshore gas project), especially from South African institutional investors. Furthermore, a sovereign rating could jump-start a credit rating environment for the domestic debt market and provide easier access of larger corporates and parastatals to tap domestic financial markets. Ultimately, one can expect that some of those corporates may follow the government and also issue abroad. 


\section{Box IV.1. Issuing a Eurobond}

An assumed sovereign rating in the B-range may reduce the yield spreads between Namibian and comparable South African bonds which presently range from 265 to 315 basis point (bps). It should be noted that spreads over South African bonds were in the 150 bps range about 18 months ago. Several factors could have led to this widening spread (see Box IV.2). The average interest rate of new issues of bonds is around 13 percent in Namibia, while Treasury bills presently cost around 8 percent but involve a roll-over risk.
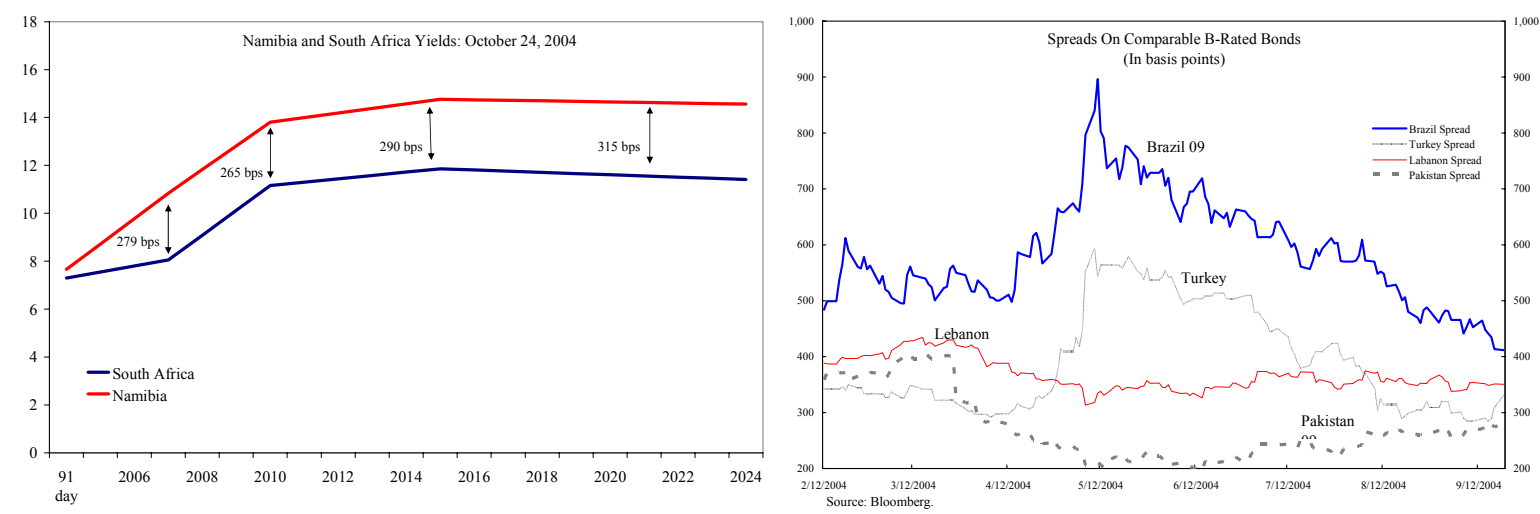

Given the present liquidity in international markets, and based on yields on B-rated sovereigns, Namibia could lower its present borrowing costs by up to $500 \mathrm{bps}$. This could involve issuing a five-year debut Eurobond at spreads of about 450 to 500 basis points over the U.S. Treasury curve, i.e., at about a 8 percent coupon-lower than the 13 percent cost of raising funds in the local market for comparable maturity.

In light of the higher-than-expected budget deficit for 2003/04, the authorities could consider issuing such bond after the results of their intended fiscal adjustment in 2004/05 are visible. However, the global interest rate cycle is on an upturn, and any rating improvement stemming from waiting for a much improved fiscal outcome in 2004/05 may be offset by an increase in global interest rates.

This being said, issuing an Eurobond needs to be carefully prepared. In addition to the timing, the authorities would in particular need to be aware of the enhanced need for fiscal transparency and consider the possible drawbacks from the exchange rate risk which could be substantial.

95. More primary issues of bonds could also materialize if the authorities considered introducing restrictions by type of investment to address the large equity exposure of Namibian pension funds and insurance companies. In general, long-term investors are biased towards fixed-income instruments since their liabilities have a lengthy duration. However, in the case on Namibia, institutional investors typically hold about two-thirds of their AUM in equities-excessive when compared to both developed and emerging market countries and potentially risky. As illustrated in Text Table IV.2, many emerging market countries limit investments by pension funds to 30 to 50 percent of their total assets. Aside from the United Kingdom and the United States, the actual investments by pension funds in equities have generally been below 30 percent of their total AUM. 
Text Table IV.2. Pension Funds Portfolio Limits and Actual Asset Allocation, 2001-02 (In percent of total assets)

\begin{tabular}{|c|c|c|c|c|}
\hline & \multicolumn{2}{|c|}{ Equities } & \multicolumn{2}{|c|}{ Foreign Assets } \\
\hline & Limit $^{1}$ & Actual $^{2}$ & Limit $^{1}$ & Actual $^{2}$ \\
\hline \multicolumn{5}{|l|}{ Mature markets } \\
\hline United Kingdom & $\mathrm{P}$ & 60.9 & $\mathrm{P}$ & 22.9 \\
\hline United States & $\mathrm{P}$ & 58.8 & $\mathrm{P}$ & $11.0^{3}$ \\
\hline Germany & 30 & 0.1 & $30^{4}$ & $7.0^{3}$ \\
\hline Japan & 30 & 27.7 & $30^{5}$ & $22.9^{3}$ \\
\hline Canada & - & 28.2 & 30 & 15.0 \\
\hline France & - & $\ldots$ & - & $5.0^{3}$ \\
\hline Italy & $P$ & 4.4 & $\mathrm{P}^{6}$ & $0.0^{3}$ \\
\hline \multicolumn{5}{|l|}{ Emerging markets } \\
\hline Argentina & 49 & 6.6 & 10 & 8.9 \\
\hline Brazil & 50 & 27.8 & 0 & $\ldots$ \\
\hline Chile & 39 & 9.0 & 25 & 16.4 \\
\hline Colombia & 30 & 4.3 & 10 & - \\
\hline Mexico & 0 & 0.0 & $10^{7}$ & - \\
\hline Peru & 35 & 31.3 & 8 & 7.2 \\
\hline Hungary & 50 & 13.8 & 30 & 2.5 \\
\hline Poland & 50 & 27.6 & $8^{5}$ & $0.3^{3}$ \\
\hline
\end{tabular}

Sources: IMF Global Finacial Stability Report, April 2004, page 31.

${ }^{1}$ Numbers refer to maximum allocation; P indicates that the prudent man rule applies.

${ }^{2}$ Data for mature markets are end of 2001 and for emerging markets are end of 2002.

${ }^{3} 1998$ data.

${ }^{4}$ In EU equity; 10 percent in foreign bonds are equities of non-EU countries. These limits are for pensionskassen, which are under the supervision of the insurance regulator. Other pension funds are not subject to investment limits.

${ }^{5}$ No investment limits for public employee funds.

${ }^{6}$ Securities of OECD countries not traded in regulated markets up to 50 percent; non-OECD securities traded in regulated markets limited to 5 percent (forbidden if traded in non-regulated markets).

${ }^{7}$ Only sovereign and investment grade Mexican corporate debt permitted in foreign limit.

${ }^{8}$ Polish Brady Bonds do not count against this limit. 


\section{Box IV.2. Recent Widening in Namibian Bond Spreads vis-à-vis South Africa}

The recent widening in Namibian bond spreads over South African bonds can be related to a variety of factors, including a reflection of the relative macroeconomic performance of both economies. On the one hand, South Africa's economy performed well in 2004, which, together with a generally prudent macroeconomic policy stance, has led to a recent upgrade by Moody's and a decline in its Eurobond spreads. On the other hand, while economic activity in Namibia may have outpaced that of South Africa, the recent rise in the fiscal deficit in Namibia may have exerted upward pressure on Namibian bond yields in 2004.

An econometric study was undertaken (using monthly data from early 2002 to October 2004) to shed some light on the recent widening of Namibian bond spreads vis-àvis comparable South African bonds. Variables that were found to significantly affect the dependent variable (i.e., the difference between Namibian bond spreads and comparable South African bond spreads) were the total outstanding public debt stock and the exchange rate. However, the ratio of net foreign assets to reserve money and the short-term interest rate differential were not found to be significant.

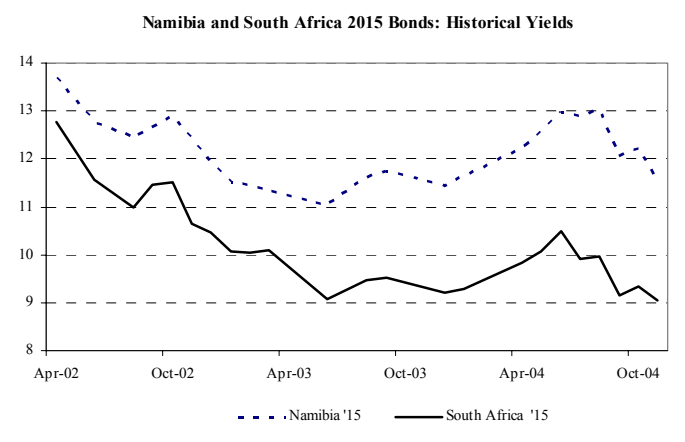

The significance of the appreciating exchange rate may be related to its differing impact on both economies. While the South African economy has been affected as well, it may have been more resilient and able to better adjust to the appreciation than Namibia. First, the impact of the rand's strength has been offset by an increase in world prices by almost 70 percent for gold and platinum-South Africa's major exports. Namibia's primary source of revenue is from the diamond sector where prices have risen to a lesser extent. Second, South Africa's trade openness indicator (i.e., exports plus imports relative to GDP) is around 54 percent, while Namibia's is around 84 percent. Thus, changes in the value of the currency would impact Namibia more. Also, South Africa's economy is well-diversified with strong retail, manufacturing, and service sectors when compared to Namibia's predominantly mining-based economy. These factors could explain why the appreciation could have affected the bond spread between Namibia and South Africa.

Finally, other factors not captured by the regression may have played a role as well, such as concerns about Namibia's land redistribution policy, political turmoil in the region, and market illiquidity. Market sources estimate that the illiquidity in the Namibian bond market adversely impacts the spreads by about 20 to 40 basis points.

96. If limits by investment were to be introduced in Namibia, such caps are likely to benefit South African bonds initially, given the limited supply of fixed-income debt instruments in Namibia at present. However, as domestic bond markets develop, pension funds and insurance companies may find sufficient domestic investment opportunities, which may help contain capital outflows.

97. Efforts could also be enhanced to improve market infrastructure. The primary market appears to be less of a concern, although settlement of new issues takes unusually long, up to one week. Regarding the secondary market, although trading takes place between asset managers, brokers, and banks, there is no uniform and transparent system in place to show bid/ask quotes. Only a privileged circle of investors has access to two-way prices. As a result, many investors perceive the market to be illiquid and are reluctant to invest in it. A 
new initiative by the Namibian Bondholders Association to provide a common platform for the reporting of prices and trading volumes, if implemented, is likely to increase the liquidity in local debt markets and could form the basis for an active secondary market.

\section{E. Conclusions}

98. One of the key features of the Namibian financial system is the large size of its institutional investors. Given the limited investment opportunities in Namibian financial markets, pension funds and insurance companies have no choice but to invest a large share of their assets abroad. There is a genuine case for developing domestic financial markets to keep a larger share of savings within Namibia, thereby helping contain the outflow of capital and safeguarding international reserves.

99. There are signs that such markets are beginning to develop in Namibia, to some extent as a result of actions taken by the authorities, such as the lengthening of the maturity profile of government securities. Other measures may not be as conducive, like the current proposals to tighten domestic asset requirements. Instead, further strengthening the benchmark role of government securities, enhancing the market infrastructure and prudential requirements, and diversifying the investor base-including by obtaining a sovereign rating and making Namibian financial markets more attractive to foreign investors, especially from South Africa - could help in this endeavor. However, since capital markets take time to develop, it can be expected that Namibia's capital account and reserves will continue to remain under pressure in the foreseeable future.

\section{References}

Bank of Namibia (2004), Annual Symposium Deliberations, August.

Bank of Namibia (2004), Quarterly Bulletin, September.

Euromoney (2004), “Africa-The Rise of a Capital Market Culture, ” November, pp.124-126.

IMF, Global Financial Stability Report, various series.

Namibia Cabinet of Ministers, Media Release, July 27, 2004.

Risk (2004), "Special Report on South Africa," November, pp. 78-84.

RMB Asset Management (2004), "Presentation to GIPF Stakeholders FunctionRegulation 28," October 2004. 
Table 1. Namibia: GDP and Gross National Income (GNI) at Current Prices, 1998-2003

(In millions of Namibia dollars, unless otherwise indicated)

\begin{tabular}{|c|c|c|c|c|c|c|}
\hline & 1998 & 1999 & 2000 & 2001 & 2002 & 2003 \\
\hline GDP at factor cost & 16,608 & 18,070 & 21,629 & 25,192 & 28,333 & 28,977 \\
\hline Compensation of employees & 7,801 & 8,307 & 9,352 & 10,616 & 11,815 & 13,014 \\
\hline Consumption of fixed capital & 2,482 & 2,851 & 3,103 & 3,561 & 3,994 & 4,396 \\
\hline Net operating surplus & 6,325 & 6,912 & 9,174 & 11,015 & 12,524 & 11,567 \\
\hline Taxes on production and imports & 2,332 & 2,771 & 2,671 & 3,158 & 3,771 & 3,929 \\
\hline Subsidies & -151 & -156 & -610 & -663 & -552 & -597 \\
\hline GDP at market prices & 18,789 & 20,630 & 23,690 & 27,686 & 31,550 & 32,309 \\
\hline Net primary incomes from rest of world & 484 & -106 & 230 & -10 & 385 & 2,483 \\
\hline Receivable from rest of world & 1,014 & 1,129 & 1,721 & 1,704 & 1,870 & 2,923 \\
\hline Payable to rest of world & -530 & $-1,235$ & $-1,491$ & $-1,714$ & $-1,485$ & -440 \\
\hline GNP at market prices & 19,273 & 20,578 & 23,920 & 27,677 & 31,935 & 34,791 \\
\hline Net current transfers & 2,243 & 2,543 & 3,010 & 2,985 & 3,111 & 3,729 \\
\hline Receivable from rest of world & 2,492 & 2,906 & 3,272 & 3,297 & 3,423 & 3,932 \\
\hline Payable to rest of world & -249 & -363 & -262 & -312 & -312 & -203 \\
\hline Gross national disposable income & 21,515 & 23,120 & 26,930 & 30,661 & 35,046 & 38,520 \\
\hline \multicolumn{7}{|l|}{ Memorandum items: } \\
\hline Real GNI at constant 1995 prices & 15,475 & 15,486 & 16,606 & 17,541 & 16,955 & 17,843 \\
\hline Percentage change & 5.8 & 0.1 & 7.2 & 5.6 & -3.3 & 5.2 \\
\hline Per capita GDP at current market prices & 10,736 & 11,459 & 12,723 & 14,853 & 16,510 & 16,509 \\
\hline Per capita GNI at current market prices & 11,013 & 11,401 & 12,846 & 14,848 & 16,711 & 17,778 \\
\hline
\end{tabular}

Source: Central Bureau of Statistics. 
Table 2. Namibia: GDP by Industrial Origin at Current Prices, 1998-2003

(In millions of Namibia dollars)

\begin{tabular}{|c|c|c|c|c|c|c|}
\hline & 1998 & 1999 & 2000 & 2001 & 2002 & 2003 \\
\hline GDP at basic prices & 16,751 & 18,177 & 21,372 & 24,916 & 28,206 & 28,828 \\
\hline Agriculture & 905 & 1,101 & 1,299 & 1,137 & 1,402 & 1,496 \\
\hline Commercial agriculture & 459 & 532 & 792 & 711 & 1,021 & 1,032 \\
\hline Subsistence agriculture & 447 & 569 & 507 & 425 & 381 & 464 \\
\hline Fishing & 934 & 917 & 1,044 & 1,445 & 1,608 & 1,627 \\
\hline Mining and quarrying & 1,835 & 1,949 & 2,610 & 3,663 & 3,945 & 2,184 \\
\hline Diamond mining & 1,358 & 1,697 & 1,934 & 2,854 & 2,887 & 1,807 \\
\hline Other mining and quarrying & 477 & 253 & 677 & 809 & 1,058 & 377 \\
\hline Subtotal, primary industries & 3,674 & 3,967 & 4,953 & 6,244 & 6,955 & 5,307 \\
\hline Manufacturing & 2,041 & 2,074 & 2,371 & 2,604 & 3,187 & 3,537 \\
\hline Meat processing & 131 & 139 & 121 & 142 & 143 & 147 \\
\hline Fish processing & 543 & 451 & 548 & 494 & 703 & 899 \\
\hline Food products and beverages & 912 & 1,014 & 1,090 & 1,215 & 1,515 & 1,599 \\
\hline Other manufacturing & 455 & 470 & 612 & 753 & 826 & 892 \\
\hline Electricity and water & 451 & 541 & 605 & 620 & 854 & 766 \\
\hline Construction & 528 & 483 & 473 & 789 & 588 & 880 \\
\hline Subtotal, secondary industries & 3,020 & 3,097 & 3,448 & 4,013 & 4,629 & 5,183 \\
\hline Wholesale and retail trade and repairs & 1,727 & 1,857 & 2,682 & 3,004 & 3,330 & 3,691 \\
\hline Hotels and restaurants & 359 & 344 & 403 & 477 & 576 & 648 \\
\hline Transport and communications & 1,111 & 1,226 & 1,383 & 1,533 & 2,055 & 2,301 \\
\hline Transport and storage & 698 & 787 & 877 & 975 & 1,266 & 1,379 \\
\hline Post and telecommunications & 413 & 439 & 506 & 558 & 789 & 922 \\
\hline Finance, real estate, and business services & 2,223 & 2,504 & 2,794 & 3,131 & 3,369 & 3,719 \\
\hline Financial intermediation & 641 & 739 & 833 & 964 & 1,088 & 1,194 \\
\hline Financial services indirectly measured & -216 & -259 & -273 & -330 & -359 & -419 \\
\hline Real estate and business services & 1,798 & 2,023 & 2,235 & 2,497 & 2,639 & 2,944 \\
\hline Owner-occupied dwellings & 956 & 1,070 & 1,194 & 1,317 & 1,427 & 1,568 \\
\hline Other real estate and business services & 841 & 953 & 1,041 & 1,180 & 1,212 & 1,375 \\
\hline Community, social, and personal services & 155 & 171 & 201 & 216 & 244 & 267 \\
\hline General government & 4,128 & 4,620 & 5,071 & 5,810 & 6,494 & 7,104 \\
\hline Other producers & 354 & 392 & 437 & 487 & 555 & 608 \\
\hline Subtotal, tertiary industries & 10,057 & 11,112 & 12,971 & 14,659 & 16,622 & 18,338 \\
\hline GDP at market prices & 18,789 & 20,630 & 23,690 & 27,686 & 31,550 & 32,309 \\
\hline
\end{tabular}

Sources: Namibian authorities; and Fund staff estimates. 
Table 3. Namibia: GDP by Industrial Origin at Constant 1995 Prices, 1998-2003

\begin{tabular}{|c|c|c|c|c|c|c|}
\hline & 1998 & 1999 & 2000 & 2001 & 2002 & 2003 \\
\hline & \multicolumn{6}{|c|}{ (In millions of Namibia dollars) } \\
\hline GDP at constant basic prices & $12,336.4$ & $12,724.2$ & $13,211.2$ & $13,487.6$ & $13,797.3$ & $14,367.6$ \\
\hline Agriculture & 909.4 & $1,008.9$ & $1,056.4$ & 899.0 & 855.8 & 879.6 \\
\hline Commercial agriculture & 489.0 & 494.6 & 648.3 & 588.9 & 601.3 & 622.9 \\
\hline Subsistence agriculture & 420.4 & 514.4 & 408.1 & 310.1 & 254.5 & 256.7 \\
\hline Fishing & 566.9 & 559.2 & 640.6 & 630.6 & 702.7 & 729.3 \\
\hline Mining and quarrying & $1,116.6$ & $1,210.4$ & $1,189.7$ & $1,117.1$ & $1,160.3$ & $1,107.3$ \\
\hline Diamond mining & 792.7 & 907.5 & 846.5 & 803.1 & 838.2 & 799.5 \\
\hline Other mining and quarrying & 323.8 & 302.9 & 343.2 & 314.0 & 322.1 & 307.8 \\
\hline Subtotal, primary industries & $2,592.9$ & $2,778.5$ & $2,886.6$ & $2,646.8$ & $2,718.8$ & $2,716.2$ \\
\hline Manufacturing & $1,573.8$ & $1,515.5$ & $1,570.0$ & $1,657.1$ & $1,739.4$ & $1,831.2$ \\
\hline Meat processing & 98.9 & 111.4 & 100.5 & 107.0 & 109.2 & 101.3 \\
\hline Fish processing & 355.8 & 280.7 & 240.8 & 204.0 & 183.4 & 277.9 \\
\hline Manufacture of other food & 725.5 & 759.3 & 773.8 & 808.2 & 875.3 & 843.8 \\
\hline Other manufacturing & 393.6 & 364.1 & 454.9 & 537.9 & 571.4 & 608.3 \\
\hline Electricity and water & 223.1 & 268.3 & 299.1 & 227.9 & 230.4 & 255.1 \\
\hline Construction & 422.8 & 364.1 & 344.4 & 527.4 & 373.5 & 546.8 \\
\hline Subtotal, secondary industries & $2,219.7$ & $2,147.8$ & $2,213.5$ & $2,412.4$ & $2,343.3$ & $2,633.1$ \\
\hline Wholesale and retail trade and repairs & $1,336.4$ & $1,380.3$ & $1,455.5$ & $1,496.3$ & $1,541.5$ & $1,580.2$ \\
\hline Hotels and restaurants & 284.6 & 251.2 & 269.2 & 291.8 & 316.4 & 332.0 \\
\hline Transport and communications & 862.4 & 968.2 & $1,049.5$ & $1,195.7$ & $1,314.9$ & $1,384.9$ \\
\hline Transport and storage & 533.0 & 631.1 & 670.7 & 725.0 & 823.6 & 776.8 \\
\hline Post and telecommunications & 329.4 & 337.1 & 378.8 & 470.7 & 491.3 & 608.0 \\
\hline Finance, real estate, and business services & $1,578.5$ & $1,627.7$ & $1,676.8$ & $1,732.8$ & $1,740.6$ & $1,807.7$ \\
\hline Financial intermediation & 450.5 & 461.1 & 489.5 & 497.6 & 514.2 & 522.3 \\
\hline Financial services indirectly measured & -144.3 & -152.2 & -150.9 & -157.8 & -154.7 & -167.8 \\
\hline Real estate and business services & $1,272.3$ & $1,318.8$ & $1,338.3$ & $1,393.0$ & $1,381.0$ & $1,453.3$ \\
\hline Owner-occupied dwellings & 660.1 & 676.6 & 693.6 & 711.0 & 728.8 & 747.1 \\
\hline Other real estate and business services & 612.2 & 642.1 & 644.7 & 682.0 & 652.3 & 706.2 \\
\hline Community, social, and personal services & 121.7 & 122.1 & 132.7 & 133.0 & 136.8 & 145.7 \\
\hline General government & $3,059.7$ & $3,162.3$ & $3,235.6$ & $3,280.6$ & $3,380.2$ & $3,456.5$ \\
\hline Other producers & 280.5 & 286.1 & 291.8 & 298.3 & 304.8 & 311.5 \\
\hline Subtotal, tertiary industries & $7,523.8$ & $7,797.9$ & $8,111.1$ & $8,428.4$ & $8,735.2$ & $9,018.4$ \\
\hline GDP at constant 1995 prices & $14,141.6$ & $14,617.5$ & $15,127.5$ & $15,490.8$ & $15,877.4$ & $16,469.1$ \\
\hline \multicolumn{7}{|l|}{ Memorandum items: } \\
\hline GDP at current basic prices & $16,751.3$ & $18,230.8$ & $21,372.0$ & $24,915.8$ & $28,206.0$ & $28,827.8$ \\
\hline GDP deflator & 132.9 & 141.5 & 156.6 & 179.1 & 199.1 & 196.5 \\
\hline GDP at current market prices & $18,788.6$ & $20,683.8$ & $23,689.7$ & $27,686.5$ & $31,550.2$ & $32,308.7$ \\
\hline
\end{tabular}

Source: Central Bureau of Statistics.

(C) International Monetary Fund. Not for Redistribution 
Table 4. Namibia: GDP by Industrial Origin at Constant 1995 Prices, 1998-2003

(Annual percentage change)

\begin{tabular}{|c|c|c|c|c|c|c|}
\hline & 1998 & 1999 & 2000 & 2001 & 2002 & 2003 \\
\hline GDP at constant basic prices & 3.4 & 3.1 & 3.6 & 2.1 & 2.3 & 4.1 \\
\hline Agriculture & -1.8 & 10.9 & 4.7 & -15.2 & -4.8 & 2.8 \\
\hline Commercial agriculture & -5.8 & 1.1 & 31.1 & -9.7 & 2.1 & 3.6 \\
\hline Subsistence agriculture & 3.2 & 22.4 & -20.7 & -24.0 & -17.9 & 0.9 \\
\hline Fishing & 21.9 & -1.4 & 14.5 & -2.6 & 11.4 & 3.8 \\
\hline Mining and quarrying & -2.5 & 8.4 & -1.7 & -6.0 & 3.9 & -4.6 \\
\hline Diamond mining & 1.3 & 14.5 & -6.7 & -5.1 & 4.4 & -4.6 \\
\hline Other mining and quarrying & -10.8 & -6.5 & 13.3 & -8.2 & 2.6 & -4.5 \\
\hline Subtotal, primary industries & 2.2 & 7.2 & 3.9 & -8.6 & 2.7 & -0.1 \\
\hline Manufacturing & 8.9 & -3.7 & 3.6 & 6.0 & 5.0 & 5.3 \\
\hline Meat processing & 8.0 & 12.6 & -9.7 & 5.9 & 2.1 & -7.3 \\
\hline Fish processing & 35.7 & -21.1 & -14.5 & -15.7 & -10.1 & 51.5 \\
\hline Manufacture of other food & 10.9 & 4.7 & 1.9 & 4.4 & 8.3 & -3.6 \\
\hline Other manufacturing & -10.0 & -7.5 & 24.9 & 20.5 & 6.2 & 6.4 \\
\hline Electricity and water & 4.3 & 20.2 & 11.5 & 3.3 & 1.1 & 10.7 \\
\hline Construction & 15.3 & -13.9 & -4.4 & 49.4 & -29.2 & 46.4 \\
\hline Subtotal, secondary industries & 9.6 & -3.2 & 3.2 & 12.5 & -2.9 & 12.4 \\
\hline Wholesale and retail trade and repairs & 7.1 & 3.3 & 5.4 & 2.8 & 3.0 & 2.5 \\
\hline Hotels and restaurants & 11.9 & -11.7 & 7.2 & 8.4 & 8.4 & 4.9 \\
\hline Transport and communications & -10.3 & 12.3 & 5.8 & 6.2 & 10.0 & 5.3 \\
\hline Transport and storage & -20.8 & 18.4 & 6.3 & 8.1 & 13.6 & -5.7 \\
\hline Post and telecommunications & 14.0 & 2.3 & 4.8 & 2.6 & 4.4 & 23.8 \\
\hline Finance, real estate, and business services & 9.9 & 12.6 & 11.7 & 11.9 & 0.4 & 3.9 \\
\hline Financial intermediation & 6.5 & 2.4 & 6.2 & 2.7 & 3.3 & 1.6 \\
\hline Financial services indirectly measured & 5.1 & 5.5 & -0.8 & 6.1 & -1.9 & 8.5 \\
\hline Real estate and business services & 2.4 & 3.7 & 1.5 & 4.1 & -0.9 & 5.2 \\
\hline Owner-occupied dwellings & 2.5 & 2.5 & 2.5 & 2.5 & 2.5 & 2.5 \\
\hline Other real estate and business services & 2.2 & 4.9 & 0.4 & 5.8 & -4.4 & 8.3 \\
\hline Community, social, and personal services & 0.0 & 0.3 & 8.7 & 0.1 & 2.9 & 6.5 \\
\hline General government & 2.7 & 3.3 & 2.4 & 1.8 & 3.0 & 2.3 \\
\hline Other producers & 2.0 & 2.0 & 2.0 & 2.0 & 2.2 & 2.2 \\
\hline Subtotal, tertiary industries & 2.1 & 3.7 & 3.6 & 3.1 & 3.6 & 3.2 \\
\hline GDP at constant 1995 prices & 3.3 & 3.4 & 3.5 & 2.4 & 2.5 & 3.7 \\
\hline \multicolumn{7}{|l|}{ Memorandum items: } \\
\hline GDP at current basic prices & 3.4 & 3.1 & 3.6 & 2.1 & 13.2 & 2.2 \\
\hline GDP deflator & 8.6 & 6.5 & 11.0 & 14.3 & 11.2 & -1.3 \\
\hline GDP at current market prices & 12.2 & 10.1 & 16.0 & 13.5 & 14.0 & 2.4 \\
\hline
\end{tabular}

Source: Central Bureau of Statistics.

CInternational Monetary Fund. Not for Redistribution 
Table 5. Namibia: Expenditure on GDP, 1998-2003

\begin{tabular}{|c|c|c|c|c|c|c|}
\hline & 1998 & 1999 & 2000 & 2001 & 2002 & 2003 \\
\hline & \multicolumn{6}{|c|}{ (In millions of Namibia dollars) } \\
\hline Expenditure on GDP at market prices & 18,789 & 20,630 & 23,690 & 27,686 & 31,550 & 32,309 \\
\hline Gross domestic expenditure & 21,241 & 22,625 & 24,653 & 29,573 & 33,616 & 34,956 \\
\hline Final consumption expenditure & 16,402 & 17,808 & 20,022 & 23,088 & 28,195 & 27,612 \\
\hline General government & 5,915 & 6,562 & 7,116 & 8,351 & 9,291 & 10,161 \\
\hline Private & 10,487 & 11,246 & 12,906 & 14,736 & 18,905 & 17,451 \\
\hline Gross capital formation & 4,321 & 4,760 & 4,460 & 6,073 & 5,892 & 7,111 \\
\hline Public & 1,447 & 2,270 & 1,451 & 2,417 & 2,175 & 2,736 \\
\hline $\begin{array}{l}\text { Producers of government } \\
\text { services }\end{array}$ & 808 & 935 & 952 & 1,059 & 1,165 & 1,187 \\
\hline \multicolumn{7}{|l|}{ Public corporations and } \\
\hline Private & 2,875 & 2,490 & 3,008 & 3,656 & 3,718 & 4,375 \\
\hline Changes in inventories & 518 & 57 & 171 & 412 & -471 & 233 \\
\hline Net exports & $-2,452$ & $-1,995$ & -963 & $-1,886$ & $-2,066$ & $-2,647$ \\
\hline Exports of goods and services & 8,448 & 9,290 & 10,471 & 12,006 & 13,753 & 12,159 \\
\hline Imports of goods and services & $-10,900$ & $-11,286$ & $-11,435$ & $-13,892$ & $-15,819$ & $-14,806$ \\
\hline & \multicolumn{6}{|c|}{ (In percent of GDP) } \\
\hline Gross domestic expenditure & 113.1 & 109.7 & 104.1 & 106.8 & 106.5 & 108.2 \\
\hline Final consumption expenditure & 87.3 & 86.3 & 84.5 & 83.4 & 89.4 & 85.5 \\
\hline General government & 31.5 & 31.8 & 30.0 & 30.2 & 29.4 & 31.4 \\
\hline Private & 55.8 & 54.5 & 54.5 & 53.2 & 59.9 & 54.0 \\
\hline Gross capital formation & 23.0 & 23.1 & 18.8 & 21.9 & 18.7 & 22.0 \\
\hline Public & 7.7 & 11.0 & 6.1 & 8.7 & 6.9 & 8.5 \\
\hline Private & 15.3 & 12.1 & 12.7 & 13.2 & 11.8 & 13.5 \\
\hline Changes in inventories & 2.8 & 0.3 & 0.7 & 1.5 & -1.5 & 0.7 \\
\hline Net exports & -13.1 & -9.7 & -4.1 & -6.8 & -6.5 & -8.2 \\
\hline Exports of goods and services & 45.0 & 45.0 & 44.2 & 43.4 & 43.6 & 37.6 \\
\hline Imports of goods and services & -58.0 & -54.7 & -48.3 & -50.2 & -50.1 & -45.8 \\
\hline
\end{tabular}

Sources: Namibian authorities; and Fund staff estimates. 
Table 6. Namibia: Output of Selected Minerals, 1998-2003

\begin{tabular}{|c|c|c|c|c|c|c|}
\hline & 1998 & 1999 & 2000 & 2001 & 2002 & 2003 \\
\hline & \multicolumn{6}{|c|}{ (In millions of Namibia dollars) } \\
\hline Diamond (thousands of carats) & $1,467.2$ & $1,634.8$ & $1,551.6$ & $1,495.0$ & $1,552.0$ & $1,481.0$ \\
\hline Uranium (tons) & $3,590.0$ & $3,495.7$ & $3,201.0$ & $2,640.0$ & $2,751.0$ & $2,401.0$ \\
\hline Copper (thousands of tons) & 8.7 & 0.1 & 24.2 & 110.4 & 17.9 & 26.3 \\
\hline Lead (thousands of tons) & 0.3 & 5.1 & 20.7 & 26.2 & $\ldots$ & $\ldots$ \\
\hline Zinc (thousands of tons) & 78.7 & 70.5 & 73.5 & 70.6 & 77.6 & 107.9 \\
\hline \multirow[t]{2}{*}{ Gold (kilograms) } & $1,880.0$ & $2,005.0$ & $2,417.0$ & $2,851.0$ & $2,815.0$ & $2,425.0$ \\
\hline & \multicolumn{6}{|c|}{ (In percent change) } \\
\hline Diamond & 3.4 & 11.4 & -5.1 & -3.6 & 3.8 & -4.6 \\
\hline Uranium & -4.9 & -2.6 & -8.4 & -17.5 & 4.2 & -12.7 \\
\hline Copper & -65.2 & -98.9 & $24,081.0$ & 356.5 & -83.8 & 46.9 \\
\hline Lead & -80.0 & $1,600.0$ & 305.2 & 26.7 & $\ldots$ & $\ldots$ \\
\hline Zinc & 8.1 & -10.4 & 4.3 & -4.0 & 9.9 & 39.0 \\
\hline Gold & -22.2 & 6.6 & 20.5 & 18.0 & -1.3 & -13.9 \\
\hline
\end{tabular}

Source: Ministry of Mines and Energy. 
Table 7. Namibia: Harvest of Main Commercial Fishing Species, 1999-2003

\begin{tabular}{|c|c|c|c|c|c|}
\hline & 1999 & 2000 & 2001 & 2002 & 2003 \\
\hline & \multicolumn{5}{|c|}{ (In metric tonnes) } \\
\hline Fish species & 577,838 & 587,832 & 554,998 & 623,391 & 631,121 \\
\hline Pilchard & 44,653 & 25,388 & 10,763 & 4,160 & 22,255 \\
\hline Hake & 164,250 & 171,397 & 173,277 & 154,588 & 189,305 \\
\hline Horse mackerel & 320,394 & 344,314 & 315,245 & 359,183 & 360,447 \\
\hline Monk & 14,802 & 14,358 & 12,390 & 15,174 & 13,135 \\
\hline Kingklip & 3,706 & 3,922 & 6,607 & 7,210 & 6,603 \\
\hline Tuna & 1,155 & 2,401 & 3,198 & 2,837 & 3,371 \\
\hline Crab & 2,074 & 2,700 & 2,343 & 2,471 & 2,092 \\
\hline Rock lobster & 304 & 365 & 365 & 361 & 269 \\
\hline Other species & 26,500 & 22,987 & 30,810 & 77,407 & 33,644 \\
\hline \multicolumn{6}{|l|}{ Other species } \\
\hline Seals (numbers) & 25,161 & 41,753 & 44,223 & 40,000 & 34,000 \\
\hline Seaweed (gracilaria collection) & 6,600 & 829 & 800 & 500 & 288 \\
\hline & \multicolumn{5}{|c|}{ (In percent change) } \\
\hline Fish species & $\ldots$ & 1.7 & -5.6 & 12.3 & 1.2 \\
\hline Pilchard & $\ldots$ & -43.1 & -57.6 & -61.3 & 435.0 \\
\hline Hake & $\ldots$ & 4.4 & 1.1 & -10.8 & 22.5 \\
\hline Horse mackerel & $\ldots$ & 7.5 & -8.4 & 13.9 & 0.4 \\
\hline Monk & $\ldots$ & -3.0 & -13.7 & 22.5 & -13.4 \\
\hline Kingklip & $\ldots$ & 5.8 & 68.5 & 9.1 & -8.4 \\
\hline Tuna & $\ldots$ & 107.9 & 33.2 & -11.3 & 18.8 \\
\hline Crab & $\ldots$ & 30.2 & -13.2 & 5.5 & -15.3 \\
\hline Rock lobster & $\ldots$ & 20.1 & 0.0 & -1.1 & -25.5 \\
\hline Other species & $\ldots$ & -13.3 & 34.0 & 151.2 & -56.5 \\
\hline \multicolumn{6}{|l|}{ Other species } \\
\hline Seals (numbers) & $\ldots$ & 65.9 & 5.9 & -9.5 & -15.0 \\
\hline Seaweed (gracilaria collection) & $\ldots$ & -87.4 & -3.5 & -37.5 & -42.4 \\
\hline
\end{tabular}

Source: Ministry of Fisheries and Marine Resources. 
Table 8. Namibia: Consumer Price Index (Windhoek), January 2001-November 2004

(Index, December 1992=100)

\begin{tabular}{|c|c|c|c|c|c|c|c|c|c|c|}
\hline & Food & $\begin{array}{r}\text { Beverages } \\
\text { and } \\
\text { Tobacco } \\
\end{array}$ & $\begin{array}{r}\text { Housing, } \\
\text { Fuel, and } \\
\text { Power }\end{array}$ & $\begin{array}{r}\begin{array}{r}\text { Clothing } \\
\text { and }\end{array} \\
\text { Footwear }\end{array}$ & $\begin{array}{l}\text { Household } \\
\text { Goods, etc. }\end{array}$ & $\begin{array}{r}\text { Transport } \\
\text { and Comm- } \\
\text { unications } \\
\end{array}$ & $\begin{array}{r}\text { Recreation, } \\
\text { etc. }\end{array}$ & $\begin{array}{r}\text { Medical } \\
\text { Health } \\
\text { Care }\end{array}$ & $\begin{array}{l}\text { Miscellan- } \\
\text { eous Goods } \\
\text { and Services }\end{array}$ & $\begin{array}{r}\text { All } \\
\text { Items }\end{array}$ \\
\hline Weights & 28.4 & 4.1 & 19.9 & 4.3 & 10.2 & 20.7 & 4.1 & 1.4 & 6.9 & 100.0 \\
\hline \multicolumn{11}{|l|}{2001} \\
\hline January & 183.2 & 275.0 & 214.7 & 193.3 & 147.6 & 202.6 & 237.0 & 241.0 & 220.9 & 199.7 \\
\hline February & 185.3 & 275.7 & 214.7 & 193.8 & 148.4 & 202.7 & 240.2 & 241.0 & 225.5 & 200.9 \\
\hline March & 187.7 & 285.8 & 216.3 & 194.5 & 149.2 & 208.3 & 233.0 & 241.7 & 225.9 & 203.3 \\
\hline April & 188.9 & 288.2 & 216.3 & 192.7 & 150.3 & 210.1 & 233.1 & 241.8 & 227.0 & 204.2 \\
\hline May & 189.0 & 288.6 & 216.3 & 194.2 & 151.3 & 210.0 & 233.7 & 242.1 & 228.1 & 204.5 \\
\hline June & 190.7 & 291.7 & 218.1 & 192.8 & 151.8 & 218.7 & 233.6 & 242.4 & 226.0 & 207.1 \\
\hline July & 190.2 & 291.2 & 217.3 & 196.5 & 151.7 & 222.6 & 232.5 & 242.4 & 228.3 & 207.8 \\
\hline August & 190.8 & 292.0 & 217.3 & 198.3 & 152.1 & 222.6 & 232.5 & 242.7 & 230.2 & 208.3 \\
\hline September & 193.8 & 296.3 & 219.4 & 199.1 & 152.7 & 223.0 & 232.2 & 242.6 & 230.3 & 209.9 \\
\hline October & 196.8 & 300.2 & 220.1 & 199.2 & 154.1 & 223.0 & 232.2 & 242.5 & 231.4 & 211.3 \\
\hline November & 199.7 & 298.7 & 220.2 & 199.1 & 155.4 & 223.0 & 236.3 & 243.5 & 231.6 & 212.4 \\
\hline December & 204.5 & 299.7 & 221.3 & 199.3 & 155.5 & 226.1 & 236.8 & 243.7 & 232.2 & 214.8 \\
\hline Average & 191.7 & 290.3 & 217.7 & 196.1 & 151.7 & 216.0 & 234.4 & 242.3 & 228.1 & 207.0 \\
\hline \multicolumn{11}{|l|}{2002} \\
\hline January & 208.4 & 303.5 & 221.3 & 203.3 & 156.0 & 226.3 & 246.6 & 248.1 & 235.4 & 217.0 \\
\hline February & 210.4 & 302.5 & 221.3 & 206.6 & 156.0 & 227.4 & 247.0 & 248.9 & 236.8 & 218.0 \\
\hline March & 215.9 & 308.7 & 223.2 & 206.6 & 157.5 & 235.7 & 247.3 & 250.0 & 239.8 & 222.3 \\
\hline April & 220.3 & 317.9 & 223.2 & 206.9 & 160.1 & 238.9 & 248.6 & 250.0 & 243.0 & 225.1 \\
\hline May & 223.6 & 319.4 & 224.2 & 207.7 & 161.3 & 238.9 & 249.2 & 252.0 & 245.7 & 226.7 \\
\hline June & 225.1 & 319.5 & 228.1 & 207.7 & 164.8 & 239.4 & 253.3 & 254.0 & 249.8 & 228.9 \\
\hline July & 230.3 & 320.9 & 236.8 & 207.8 & 166.4 & 240.1 & 254.5 & 255.0 & 249.7 & 232.5 \\
\hline August & 230.5 & 323.1 & 236.8 & 209.1 & 166.6 & 242.2 & 254.5 & 255.1 & 248.9 & 233.1 \\
\hline September & 236.4 & 327.7 & 239.1 & 208.5 & 167.3 & 250.4 & 255.6 & 255.4 & 251.5 & 237.4 \\
\hline October & 244.0 & 305.7 & 239.1 & 213.0 & 166.9 & 253.0 & 256.4 & 263.3 & 251.5 & 239.5 \\
\hline November & 251.4 & 305.6 & 239.0 & 213.0 & 167.0 & 253.0 & 256.4 & 263.6 & 251.0 & 241.6 \\
\hline December & 253.7 & 313.4 & 239.8 & 215.5 & 168.2 & 257.8 & 257.2 & 263.9 & 251.8 & 244.0 \\
\hline Average & 229.2 & 314.0 & 231.0 & 208.8 & 163.2 & 241.9 & 252.2 & 254.9 & 246.2 & 230.5 \\
\hline \multicolumn{11}{|l|}{2003} \\
\hline January & 254.5 & 314.2 & 239.9 & 215.1 & 168.5 & 256.0 & 276.9 & 269.9 & 252.4 & 244.8 \\
\hline February & 249.4 & 314.1 & 239.8 & 215.2 & 169.0 & 256.4 & 277.1 & 269.1 & 254.5 & 243.6 \\
\hline March & 247.4 & 326.9 & 245.4 & 199.9 & 168.7 & 254.6 & 277.0 & 269.8 & 259.6 & 244.0 \\
\hline April & 243.3 & 338.7 & 245.4 & 204.4 & 170.7 & 252.1 & 278.1 & 270.7 & 261.5 & 243.4 \\
\hline May & 245.7 & 342.0 & 245.4 & 201.8 & 171.4 & 252.1 & 279.6 & 270.7 & 283.5 & 245.8 \\
\hline June & 247.4 & 350.2 & 246.0 & 204.3 & 172.5 & 257.2 & 279.0 & 270.0 & 287.8 & 248.2 \\
\hline July & 245.3 & 355.2 & 252.1 & 205.1 & 172.6 & 255.2 & 279.7 & 270.3 & 291.7 & 249.0 \\
\hline August & 244.5 & 352.2 & 252.1 & 204.5 & 172.5 & 255.2 & 280.5 & 274.5 & 291.9 & 248.7 \\
\hline September & 245.1 & 355.4 & 251.4 & 202.5 & 171.6 & 257.1 & 280.6 & 275.2 & 295.3 & 249.3 \\
\hline October & 248.0 & 355.4 & 251.3 & 200.4 & 171.9 & 251.0 & 278.3 & 276.0 & 294.9 & 248.7 \\
\hline November & 253.6 & 354.7 & 251.4 & 199.7 & 172.0 & 251.0 & 278.5 & 276.0 & 294.3 & 250.2 \\
\hline December & 250.0 & 355.2 & 251.4 & 199.4 & 170.5 & 250.9 & 278.3 & 276.4 & 293.4 & 249.0 \\
\hline Average & 247.8 & 342.9 & 247.6 & 204.3 & 171.0 & 254.0 & 278.6 & 272.4 & 280.1 & 247.1 \\
\hline \multicolumn{11}{|l|}{2004} \\
\hline January & 250.9 & 355.4 & 251.4 & 199.4 & 171.3 & 249.3 & 300.6 & 301.5 & 299.5 & 250.7 \\
\hline February & 251.9 & 362.7 & 251.4 & 206.0 & 171.5 & 249.2 & 298.9 & 301.8 & 303.1 & 251.7 \\
\hline March & 254.6 & 371.1 & 254.7 & 203.0 & 170.2 & 249.5 & 300.2 & 302.0 & 302.4 & 253.3 \\
\hline April & 252.1 & 369.7 & 254.8 & 204.6 & 170.9 & 253.5 & 299.7 & 301.7 & 300.5 & 253.4 \\
\hline May & 252.4 & 372.2 & 254.9 & 210.1 & 171.8 & 252.5 & 299.8 & 302.2 & 301.2 & 253.7 \\
\hline June & 251.0 & 373.3 & 254.4 & 210.9 & 172.2 & 253.2 & 297.0 & 301.7 & 306.0 & 253.7 \\
\hline July & 250.5 & 373.8 & 270.2 & 210.9 & 171.8 & 258.9 & 299.6 & 302.1 & 305.4 & 258.0 \\
\hline August & 252.5 & 374.5 & 271.1 & 212.4 & 172.3 & 258.9 & 300.1 & 301.9 & 310.2 & 259.2 \\
\hline September & 251.7 & 376.4 & 272.0 & 214.9 & 172.3 & 259.0 & 301.3 & 305.8 & 311.1 & 259.5 \\
\hline October & 256.2 & 379.3 & 271.9 & 214.4 & 171.7 & 259.0 & 301.7 & 305.4 & 311.2 & 260.8 \\
\hline November & 255.6 & 384.4 & 272.5 & 214.9 & 172.6 & 267.6 & 301.7 & 305.4 & 308.1 & 262.7 \\
\hline
\end{tabular}


Table 9. Namibia: Financial Operations of the Central Government, 1998/99-2003/04 1/

(In millions of Namibia dollars)

\begin{tabular}{|c|c|c|c|c|c|c|}
\hline & 1998/99 & $1999 / 00$ & $2000 / 01$ & $2001 / 02$ & $2002 / 03$ & 2003/04 \\
\hline Revenue and grants & 6,132 & 7,228 & 8,209 & 8,960 & 10,469 & 9,754 \\
\hline Revenue & 6,095 & 7,183 & 8,166 & 8,902 & 10,435 & 9,720 \\
\hline Tax revenue & 5,403 & 6,486 & 7,461 & 8,054 & 9,196 & 8,633 \\
\hline Personal income tax & 1,241 & 1,509 & 1,507 & 1,833 & 2,181 & 2,334 \\
\hline Corporate income tax & 721 & 713 & 903 & 1,335 & 2,113 & 1,198 \\
\hline Diamond mining & 161 & 143 & 440 & 764 & 1,157 & 175 \\
\hline Other mining & 19 & 212 & 36 & 106 & 284 & 3 \\
\hline Non-mining & 540 & 359 & 426 & 465 & 672 & 1,020 \\
\hline VAT and sales taxes & 1,273 & 1,470 & 1,766 & 1,938 & 2,009 & 1,756 \\
\hline International taxes (SACU receipts) 2/ & 1,805 & 2,241 & 2,877 & 2,641 & 2,597 & 3,036 \\
\hline Other & 363 & 553 & 407 & 306 & 296 & 309 \\
\hline Nontax revenue & 691 & 697 & 704 & 847 & 1,239 & 1,087 \\
\hline Diamond royalties & 199 & 270 & 240 & 286 & 479 & 302 \\
\hline Administrative fees, including license revenues & 259 & 210 & 237 & 258 & 388 & 461 \\
\hline Other & 233 & 217 & 227 & 303 & 372 & 324 \\
\hline Grants (tied) & 37 & 44 & 44 & 58 & 34 & 34 \\
\hline Expenditures & 6,880 & 7,736 & 8,566 & 10,256 & 11,573 & 12,344 \\
\hline Current expenditure & 6,133 & 6,705 & 7,253 & 8,717 & 9,482 & 10,387 \\
\hline Personnel & 3,169 & 3,615 & 3,720 & 4,326 & 4,709 & 5,117 \\
\hline Goods and services & 1,373 & 1,421 & 1,571 & 2,034 & 2,057 & 2,150 \\
\hline Interest payments & 489 & 492 & 533 & 587 & 823 & 865 \\
\hline Domestic & 476 & 479 & 520 & 559 & 772 & 814 \\
\hline Foreign & 13 & 13 & 13 & 28 & 52 & 51 \\
\hline Subsidies and current transfers & 1,071 & 1,141 & 1,395 & 1,770 & 1,893 & 2,255 \\
\hline Other & 30 & 36 & 34 & 0 & 0 & 0 \\
\hline Capital expenditure & 705 & 941 & 1,182 & 1,082 & 1,457 & 1,570 \\
\hline Acquisition of capital assets & 685 & 907 & 1,152 & 1,038 & 1,370 & 1,479 \\
\hline Capital transfers & 20 & 33 & 30 & 44 & 87 & 91 \\
\hline Net lending & 42 & 89 & 131 & 456 & 634 & 387 \\
\hline Overall balance 3 / & -748 & -508 & -357 & $-1,296$ & $-1,104$ & $-2,590$ \\
\hline Primary balance 3 / & -259 & -16 & 176 & -709 & -280 & $-1,725$ \\
\hline Statistical discrepancy & -157 & 95 & 345 & -132 & -27 & 22 \\
\hline Financing & 591 & 603 & 702 & 1,164 & 1,076 & 2,611 \\
\hline Domestic & 584 & 596 & 401 & 1,062 & 815 & 2,387 \\
\hline External & 7 & 6 & 301 & 103 & 261 & 224 \\
\hline Disbursements & 8 & 7 & 308 & 110 & 275 & 244 \\
\hline Amortization & -1 & -1 & -7 & -7 & -14 & -20 \\
\hline
\end{tabular}

Sources: Namibian authorities; and Fund staff estimates.

1/ Fiscal year begins April 1.

2/ Transfers from the common revenue pool (customs and excise) of the Southern African Customs Union.

3 / Includes externally financed project spending (except for roads) that is not channeled through the state account. 
Table 10. Namibia: Central Government Revenue and Grants, 1998/99-2003/04 1/

(In millions of Namibia dollars)

\begin{tabular}{|c|c|c|c|c|c|c|}
\hline & 1998/99 & $1999 / 00$ & $2000 / 01$ & $2001 / 02$ & $2002 / 03$ & $2003 / 04$ \\
\hline Tax revenue & 5,403 & 6,486 & 7,461 & 8,054 & 9,196 & 8,633 \\
\hline Taxes on income/profits & 2,031 & 2,315 & 2,610 & 3,286 & 4,442 & 3,618 \\
\hline Personal & 1,241 & 1,509 & 1,507 & 1,833 & 2,181 & 2,334 \\
\hline Corporate & 721 & 713 & 903 & 1,335 & 2,113 & 1,198 \\
\hline Mining & 181 & 354 & 476 & 871 & 1,441 & 179 \\
\hline Diamond & 161 & 143 & 440 & 764 & 1,157 & 175 \\
\hline Other mining & 19 & 212 & 36 & 106 & 284 & 3 \\
\hline Other sectors & 540 & 359 & 426 & 465 & 672 & 1,020 \\
\hline Other income/profits taxes & 69 & 93 & 200 & 117 & 149 & 86 \\
\hline Property taxes & 40 & 47 & 63 & 64 & 79 & 75 \\
\hline Taxes on goods and services & 1,527 & 1,883 & 1,911 & 2,063 & 2,077 & 1,903 \\
\hline VAT and sales taxes & 1,273 & 1,470 & 1,766 & 1,938 & 2,009 & 1,756 \\
\hline Fuel levy & 211 & 361 & 90 & 58 & -7 & 64 \\
\hline Stamp duties & 43 & 51 & 55 & 68 & 76 & 83 \\
\hline Taxes on international trade (SACU receipts) 2/ & 1,805 & 2,241 & 2,877 & 2,641 & 2,597 & 3,036 \\
\hline Nontax revenue & 691 & 697 & 704 & 847 & 1,239 & 1,087 \\
\hline Property income & 423 & 476 & 446 & 571 & 831 & 607 \\
\hline Diamond royalties & 199 & 270 & 240 & 286 & 479 & 302 \\
\hline Fishing quota levies & 44 & 73 & 83 & 108 & 128 & 118 \\
\hline Interest on loans, investments, and central bank deposits & 31 & 27 & 27 & 54 & 62 & 27 \\
\hline Dividends from parastatals & 77 & 32 & 17 & 124 & 81 & 79 \\
\hline Compensation for use of the Rand & 71 & 75 & 79 & 0 & 81 & 81 \\
\hline Administrative fees, including license revenues & 259 & 210 & 237 & 258 & 388 & 461 \\
\hline Fines and forfeitures & 9 & 11 & 21 & 18 & 20 & 19 \\
\hline Total revenue & 6,095 & 7,183 & 8,166 & 8,902 & 10,435 & 9,720 \\
\hline Grants (tied) & 37 & 44 & 44 & 58 & 34 & 34 \\
\hline Recurrent activity & 25 & 44 & 25 & 3 & 10 & 34 \\
\hline Development projects & 12 & 0 & 18 & 55 & 24 & 0 \\
\hline Revenue and grants & 6,132 & 7,228 & 8,209 & 8,960 & 10,469 & 9,754 \\
\hline
\end{tabular}

Sources: Namibian authorities; and Fund staff estimates.

1/ Fiscal year begins April 1.

2/ Transfers from the common revenue pool (customs and excise) of the Southern African Customs Union. 
Table 11. Namibia: Central Government Revenue and Grants, 1998/99-2003/04 1/

(In percent of GDP)

\begin{tabular}{|c|c|c|c|c|c|c|}
\hline Tax revenue & 28.1 & 30.3 & 30.2 & 28.1 & 29.0 & 26.1 \\
\hline Taxes on income/profits & 10.6 & 10.8 & 10.6 & 11.5 & 14.0 & 10.9 \\
\hline Personal & 6.4 & 7.1 & 6.1 & 6.4 & 6.9 & 7.1 \\
\hline Corporate & 3.7 & 3.3 & 3.7 & 4.7 & 6.7 & 3.6 \\
\hline Mining & 0.9 & 1.7 & 1.9 & 3.0 & 4.5 & 0.5 \\
\hline Diamond & 0.8 & 0.7 & 1.8 & 2.7 & 3.6 & 0.5 \\
\hline Other mining & 0.1 & 1.0 & 0.1 & 0.4 & 0.9 & 0.0 \\
\hline Other sectors & 2.8 & 1.7 & 1.7 & 1.6 & 2.1 & 3.1 \\
\hline Other income/profits taxes & 0.4 & 0.4 & 0.8 & 0.4 & 0.5 & 0.3 \\
\hline Property taxes & 0.2 & 0.2 & 0.3 & 0.2 & 0.2 & 0.2 \\
\hline Taxes on goods and services & 7.9 & 8.8 & 7.7 & 7.2 & 6.5 & 5.8 \\
\hline VAT and sales taxes & 6.6 & 6.9 & 7.2 & 6.8 & 6.3 & 5.3 \\
\hline Fuel levy & 1.1 & 1.7 & 0.4 & 0.2 & 0.0 & 0.2 \\
\hline Stamp duties & 0.2 & 0.2 & 0.2 & 0.2 & 0.2 & 0.3 \\
\hline Taxes on international trade (SACU receipts) 2/ & 9.4 & 10.5 & 11.7 & 9.2 & 8.2 & 9.2 \\
\hline Nontax revenue & 3.6 & 3.3 & 2.9 & 3.0 & 3.9 & 3.3 \\
\hline Property income & 2.2 & 2.2 & 1.8 & 2.0 & 2.6 & 1.8 \\
\hline Diamond royalties & 1.0 & 1.3 & 1.0 & 1.0 & 1.5 & 0.9 \\
\hline Fishing quota levies & 0.2 & 0.3 & 0.3 & 0.4 & 0.4 & 0.4 \\
\hline Interest on loans, investments, and central bank deposits & 0.2 & 0.1 & 0.1 & 0.2 & 0.2 & 0.1 \\
\hline Dividends from parastatals & 0.4 & 0.1 & 0.1 & 0.4 & 0.3 & 0.2 \\
\hline Compensation for use of the Rand & 0.4 & 0.3 & 0.3 & 0.0 & 0.3 & 0.2 \\
\hline Administrative fees, including license revenues & 1.3 & 1.0 & 1.0 & 0.9 & 1.2 & 1.4 \\
\hline Fines and forfeitures & 0.0 & 0.1 & 0.1 & 0.1 & 0.1 & 0.1 \\
\hline Total revenue & 31.7 & 33.6 & 33.1 & 31.1 & 32.9 & 29.4 \\
\hline Grants (tied) & 0.2 & 0.2 & 0.2 & 0.2 & 0.1 & 0.1 \\
\hline Recurrent activity & 0.1 & 0.2 & 0.1 & 0.0 & 0.0 & 0.1 \\
\hline Development projects & 0.1 & 0.0 & 0.1 & 0.2 & 0.1 & 0.0 \\
\hline Revenue and grants & 31.9 & 33.8 & 33.3 & 31.3 & 33.0 & 29.5 \\
\hline \multicolumn{7}{|l|}{ Memorandum item: } \\
\hline GDP at current market prices & 19,249 & 21,395 & 24,689 & 28,652 & 31,740 & 33,062 \\
\hline
\end{tabular}

Sources: Namibian authorities; and Fund staff estimates.

1/ Fiscal year begins April 1.

2/ Transfers from the common revenue pool (customs and excise) of the Southern African Customs Union. 
Table 12. Namibia: Central Government Expenditure, 1998/99-2003/04 1/

(In millions of Namibia dollars)

\begin{tabular}{|c|c|c|c|c|c|c|}
\hline & 1998/99 & $1999 / 00$ & $2000 / 01$ & $2001 / 02$ & $2002 / 03$ & $2003 / 04$ \\
\hline Current expenditure & 6,133 & 6,705 & 7,253 & 8,717 & 9,482 & 10,387 \\
\hline Personnel & 3,169 & 3,615 & 3,720 & 4,326 & 4,709 & 5,117 \\
\hline Wages and salaries & 2,738 & 3,078 & 3,104 & $\ldots$ & 4,106 & $\ldots$ \\
\hline Pension contributions & 336 & 432 & 445 & $\ldots$ & 508 & $\ldots$ \\
\hline Cash benefits & 95 & 105 & 171 & $\ldots$ & 95 & $\ldots$ \\
\hline Goods and services & 1,373 & 1,421 & 1,571 & 2,034 & 2,057 & 2,150 \\
\hline Interest payments & 489 & 492 & 533 & 587 & 823 & 865 \\
\hline Domestic & 476 & 479 & 520 & 559 & 772 & 814 \\
\hline Foreign & 13 & 13 & 13 & 28 & 52 & 51 \\
\hline Subsidies and current transfers & 1,071 & 1,141 & 1,395 & 1,770 & 1,893 & 2,255 \\
\hline Other current expenditure & 30 & 36 & 34 & 0 & 0 & 0 \\
\hline Capital expenditure & 705 & 941 & 1,182 & 1,082 & 1,457 & 1,570 \\
\hline Acquisition of capital assets $2 /$ & 685 & 907 & 1,152 & 1,038 & 1,370 & 1,479 \\
\hline Capital transfers & 20 & 33 & 30 & 44 & 87 & 91 \\
\hline Net lending & 42 & 89 & 131 & 456 & 634 & 387 \\
\hline Lending & 96 & 109 & 152 & 478 & 650 & 400 \\
\hline Repayments & -54 & -20 & -21 & -21 & -16 & -13 \\
\hline Total expenditure and net lending & 6,880 & 7,736 & 8,566 & 10,256 & 11,573 & 12,344 \\
\hline
\end{tabular}

Sources: Namibian authorities; and Fund staff estimates.

1/ Fiscal year begins April 1.

2/ This includes externally financed project spending (except for roads) that is not channeled through the state account. 
Table 13. Namibia: Central Government Expenditure, 1998/99-2003/04 1/

(In percent of GDP)

\begin{tabular}{|c|c|c|c|c|c|c|}
\hline & 1998/99 & $1999 / 00$ & $2000 / 01$ & $2001 / 02$ & $2002 / 03$ & $2003 / 04$ \\
\hline Current expenditure & 31.9 & 31.3 & 29.4 & 30.4 & 29.9 & 31.4 \\
\hline Personnel & 16.5 & 16.9 & 15.1 & 15.1 & 14.8 & 15.5 \\
\hline Wages and salaries & 14.2 & 14.4 & 12.6 & $\ldots$ & 12.9 & .. \\
\hline Pension contributions & 1.7 & 2.0 & 1.8 & $\ldots$ & 1.6 & .. \\
\hline Cash benefits & 0.5 & 0.5 & 0.7 & $\ldots$ & 0.3 & .. \\
\hline Goods and services & 7.1 & 6.6 & 6.4 & 7.1 & 6.5 & 6.5 \\
\hline Interest payments & 2.5 & 2.3 & 2.2 & 2.0 & 2.6 & 2.6 \\
\hline Domestic & 2.5 & 2.2 & 2.1 & 2.0 & 2.4 & 2.5 \\
\hline Foreign & 0.1 & 0.1 & 0.1 & 0.1 & 0.2 & 0.2 \\
\hline Subsidies and current transfers & 5.6 & 5.3 & 5.7 & 6.2 & 6.0 & 6.8 \\
\hline Other current expenditure & 0.2 & 0.2 & 0.1 & 0.0 & 0.0 & 0.0 \\
\hline Capital expenditure & 3.7 & 4.4 & 4.8 & 3.8 & 4.6 & 4.7 \\
\hline Acquisition of capital assets 2/ & 3.6 & 4.2 & 4.7 & 3.6 & 4.3 & 4.5 \\
\hline Capital transfers & 0.1 & 0.2 & 0.1 & 0.2 & 0.3 & 0.3 \\
\hline Net lending & 0.2 & 0.4 & 0.5 & 1.6 & 2.0 & 1.2 \\
\hline Lending & 0.5 & 0.5 & 0.6 & 1.7 & 2.0 & 1.2 \\
\hline Repayments & -0.3 & -0.1 & -0.1 & -0.1 & -0.1 & 0.0 \\
\hline Total expenditure and net lending & 35.7 & 36.2 & 34.7 & 35.8 & 36.5 & 37.3 \\
\hline \multicolumn{7}{|l|}{ Memorandum item: } \\
\hline GDP at current market prices & 19,249 & 21,395 & 24,689 & 28,652 & 31,740 & 33,062 \\
\hline
\end{tabular}

Sources: Namibian authorities; and Fund staff estimates.

1/ Fiscal year begins April 1.

2/ This includes externally financed project spending (except for roads) that is not channeled through the state account. 
Table 14. Namibia: Functional Classification of Central Government Expenditure, 1998/99-2003/04 1/

(In millions of Namibia dollars)

\begin{tabular}{|c|c|c|c|c|c|c|}
\hline & $1998 / 99$ & $1999 / 00$ & $2000 / 01$ & $2001 / 02$ & $2002 / 03$ & $\begin{array}{r}2003 / 04 \\
\text { Revised } \\
\text { Budget } 2 /\end{array}$ \\
\hline General government services & 1,948 & 2,224 & 2,579 & 3,114 & 3,593 & 3,576 \\
\hline General public services & 1,014 & 981 & 1,174 & 1,236 & 1,631 & 1,429 \\
\hline Defense & 443 & 559 & 617 & 905 & 935 & 994 \\
\hline Public order and safety & 492 & 684 & 788 & 973 & 1,026 & 1,153 \\
\hline Community and social affairs and services & 3,280 & 3,745 & 4,191 & 5,179 & 5,362 & 6,101 \\
\hline Education & 1,701 & 1,863 & 1,970 & 2,344 & 2,367 & 2,650 \\
\hline Health & 713 & 837 & 925 & 1,025 & 1,097 & 1,205 \\
\hline Social security and welfare & 321 & 447 & 540 & 715 & 749 & 897 \\
\hline Housing and community amenity & 380 & 418 & 556 & 880 & 949 & 1,054 \\
\hline Recreational, cultural, and religious & 166 & 179 & 200 & 216 & 200 & 294 \\
\hline Economic affairs and services & 1,045 & 1,178 & 989 & 1,045 & 1,306 & 1,289 \\
\hline Fuel and energy & 41 & 34 & 39 & 35 & 38 & 38 \\
\hline Agriculture, forestry, fishing, and hunting & 490 & 521 & 523 & 580 & 625 & 617 \\
\hline Mining and mineral resources & 26 & 37 & 46 & 54 & 52 & 57 \\
\hline Transportation and communications & 320 & 415 & 122 & 73 & 109 & 162 \\
\hline Other & 168 & 170 & 258 & 304 & 482 & 416 \\
\hline Expenditure not classified by function 3/ & 442 & 495 & 536 & 678 & 819 & 877 \\
\hline Statistical discrepancy & 122 & 5 & 140 & -218 & -140 & 114 \\
\hline Total excluding lending & 6,838 & 7,646 & 8,435 & 9,800 & 10,939 & 11,957 \\
\hline Total expenditure and net lending & 6,880 & 7,736 & 8,566 & 10,256 & 11,573 & 12,344 \\
\hline
\end{tabular}

Sources: Namibian authorities; and Fund staff estimates.

1/ Fiscal year begins April 1.

2/ Actual data on functional spending for 2003/04 are not yet available.

3/ Includes public debt transactions. 
Table 15. Namibia: Sectoral Share of Central Government Expenditure, 1998/99-2003/04 1/

\begin{tabular}{|c|c|c|c|c|c|c|}
\hline & 1998/99 & $1999 / 00$ & $2000 / 01$ & $2001 / 02$ & $2002 / 03$ & $\begin{array}{r}2003 / 04 \\
\text { Revised } \\
\text { Budget 2/ } \\
\end{array}$ \\
\hline & \multicolumn{6}{|c|}{ (In percent of total expenditure and net lending) } \\
\hline General government services & 28.3 & 28.8 & 30.1 & 30.4 & 31.0 & 29.0 \\
\hline General public services & 14.7 & 12.7 & 13.7 & 12.0 & 14.1 & 11.6 \\
\hline Defense & 6.4 & 7.2 & 7.2 & 8.8 & 8.1 & 8.1 \\
\hline Public order and safety & 7.2 & 8.8 & 9.2 & 9.5 & 8.9 & 9.3 \\
\hline Community and social affairs and services & 47.7 & 48.4 & 48.9 & 50.5 & 46.3 & 49.4 \\
\hline Education & 24.7 & 24.1 & 23.0 & 22.9 & 20.5 & 21.5 \\
\hline Health & 10.4 & 10.8 & 10.8 & 10.0 & 9.5 & 9.8 \\
\hline Social security and welfare & 4.7 & 5.8 & 6.3 & 7.0 & 6.5 & 7.3 \\
\hline Housing and community amenity & 5.5 & 5.4 & 6.5 & 8.6 & 8.2 & 8.5 \\
\hline Recreational, cultural and religious & 2.4 & 2.3 & 2.3 & 2.1 & 1.7 & 2.4 \\
\hline Economic affairs and services & 15.2 & 15.2 & 11.5 & 10.2 & 11.3 & 10.4 \\
\hline Fuel and energy & 0.6 & 0.4 & 0.5 & 0.3 & 0.3 & 0.3 \\
\hline Agriculture, forestry, fishing, and hunting & 7.1 & 6.7 & 6.1 & 5.7 & 5.4 & 5.0 \\
\hline Mining and mineral resources & 0.4 & 0.5 & 0.5 & 0.5 & 0.4 & 0.5 \\
\hline Transportation and communications & 4.7 & 5.4 & 1.4 & 0.7 & 0.9 & 1.3 \\
\hline Other & 2.4 & 2.2 & 3.0 & 3.0 & 4.2 & 3.4 \\
\hline Expenditure not classified by function 3 / & 6.4 & 6.4 & 6.3 & 6.6 & 7.1 & 7.1 \\
\hline Statistical discrepancy & 1.8 & 0.1 & 1.6 & -2.1 & -1.2 & 0.9 \\
\hline Total excluding lending & 99.4 & 98.8 & 98.5 & 95.5 & 94.5 & 96.9 \\
\hline \multirow[t]{2}{*}{ Total expenditure and net lending } & 100.0 & 100.0 & 100.0 & 100.0 & 100.0 & 100.0 \\
\hline & \multicolumn{6}{|c|}{ (In percent of GDP) } \\
\hline General government services & 10.1 & 10.4 & 10.4 & 10.9 & 11.3 & 10.8 \\
\hline General public services & 5.3 & 4.6 & 4.8 & 4.3 & 5.1 & 4.3 \\
\hline Defense & 2.3 & 2.6 & 2.5 & 3.2 & 2.9 & 3.0 \\
\hline Public order and safety & 2.6 & 3.2 & 3.2 & 3.4 & 3.2 & 3.5 \\
\hline Community and social affairs and services & 17.0 & 17.5 & 17.0 & 18.1 & 16.9 & 18.5 \\
\hline Education & 8.8 & 8.7 & 8.0 & 8.2 & 7.5 & 8.0 \\
\hline Health & 3.7 & 3.9 & 3.7 & 3.6 & 3.5 & 3.6 \\
\hline Social security and welfare & 1.7 & 2.1 & 2.2 & 2.5 & 2.4 & 2.7 \\
\hline Housing and community amenity & 2.0 & 2.0 & 2.3 & 3.1 & 3.0 & 3.2 \\
\hline Recreational, cultural and religious & 0.9 & 0.8 & 0.8 & 0.8 & 0.6 & 0.9 \\
\hline Economic affairs and services & 5.4 & 5.5 & 4.0 & 3.6 & 4.1 & 3.9 \\
\hline Fuel and energy & 0.2 & 0.2 & 0.2 & 0.1 & 0.1 & 0.1 \\
\hline Agriculture, forestry, fishing, and hunting & 2.5 & 2.4 & 2.1 & 2.0 & 2.0 & 1.9 \\
\hline Mining and mineral resources & 0.1 & 0.2 & 0.2 & 0.2 & 0.2 & 0.2 \\
\hline Transportation and communications & 1.7 & 1.9 & 0.5 & 0.3 & 0.3 & 0.5 \\
\hline Other & 0.9 & 0.8 & 1.0 & 1.1 & 1.5 & 1.3 \\
\hline Expenditure not classified by function 3/ & 2.3 & 2.3 & 2.2 & 2.4 & 2.6 & 2.7 \\
\hline Statistical discrepancy & 0.6 & 0.0 & 0.6 & -0.8 & -0.4 & 0.3 \\
\hline Total excluding lending & 35.5 & 35.7 & 34.2 & 34.2 & 34.5 & 36.2 \\
\hline Total expenditure and net lending & 35.7 & 36.2 & 34.7 & 35.8 & 36.5 & 37.3 \\
\hline \multicolumn{7}{|l|}{ Memorandum item: } \\
\hline GDP at current market prices & 19,249 & 21,395 & 24,689 & 28,652 & 31,740 & 33,062 \\
\hline
\end{tabular}

Sources: Namibian authorities; and Fund staff estimates.

1/ Fiscal year begins April 1.

2/ Actual data on functional spending for 2003/04 are not yet available.

3/ Includes public debt transactions. 
Table 16. Namibia: Outstanding Debt of Central Government, 1998/99-2003/04 1/

(In millions of Namibia dollars, unless otherwise indicated)

\begin{tabular}{|c|c|c|c|c|c|c|}
\hline & 1998/99 & $1999 / 00$ & $2000 / 01$ & $2001 / 02$ & $2002 / 03$ & $2003 / 04$ \\
\hline Domestic debt & 3,754 & 4,457 & 4,731 & 5,947 & 6,712 & 8,606 \\
\hline Treasury bills & 1,840 & 2,483 & 2,495 & 3,211 & 3,618 & 5,041 \\
\hline 91 days & 1,240 & 1,345 & 1,175 & 1,449 & 1,004 & 300 \\
\hline 182 days & 600 & 888 & 820 & 1,190 & 1,236 & 2,190 \\
\hline 365 days & 0 & 250 & 500 & 572 & 1,378 & 2,551 \\
\hline Internal registered stock (IRS) & 1,914 & 1,974 & 2,236 & 2,736 & 3,094 & 3,565 \\
\hline$<=2$ years term-to-maturity & 110 & 802 & 912 & 669 & 1,164 & 1,069 \\
\hline 3 - 5 years term-to-maturity & 632 & 503 & 618 & 985 & 442 & 655 \\
\hline $6-10$ years term-to-maturity & 503 & 669 & 706 & 1,082 & 1,213 & 1,263 \\
\hline$>=11$ years term-to-maturity & 669 & 0 & 0 & 0 & 275 & 579 \\
\hline External debt $2 /$ & 562 & 752 & 970 & 1,561 & 1,212 & 1,607 \\
\hline African Development Bank & 87 & 97 & 118 & 169 & 156 & 225 \\
\hline Kreditanstalt für Wiederaufbau (Germany) & 251 & 389 & 462 & 669 & 489 & 599 \\
\hline European Investment Bank & 101 & 109 & 155 & 376 & 155 & 254 \\
\hline Nordic Development Fund & 12 & 12 & 12 & 21 & 16 & 14 \\
\hline International Fund for Agricultural Development & 22 & 23 & 23 & 40 & 28 & 24 \\
\hline People's Republic of China & 71 & 98 & 139 & 185 & 135 & 226 \\
\hline Caisse Francaise de Developpement & 17 & 23 & 25 & 35 & 29 & 23 \\
\hline Development Bank of Southern Africa & 0 & 0 & 32 & 57 & 110 & 150 \\
\hline Arab Bank for Economic Development in Africa & 0 & 0 & 5 & 7 & 5 & 15 \\
\hline Kuwait Fund for Arab Economic Development & 0 & 0 & 0 & 1 & 0 & 0 \\
\hline EKSPORT FINANS ASA & 0 & 0 & 0 & 0 & 56 & 48 \\
\hline Instituto de Credito Oficial & 0 & 0 & 0 & 0 & 34 & 30 \\
\hline Total government debt & 4,315 & 5,208 & 5,701 & 7,507 & 7,924 & 10,213 \\
\hline Government-guaranteed debt & 835 & 1,883 & 2,718 & 3,808 & 3,258 & 3,422 \\
\hline Government and government-guaranteed debt & 5,150 & 7,091 & 8,419 & 11,315 & 11,183 & 13,635 \\
\hline & \multicolumn{6}{|c|}{ (In percent of GDP) } \\
\hline Government and government-guaranteed debt & 26.8 & 33.1 & 34.1 & 39.5 & 35.2 & 41.2 \\
\hline Government debt & 22.4 & 24.3 & 23.1 & 26.2 & 25.0 & 30.9 \\
\hline Domestic & 19.5 & 20.8 & 19.2 & 20.8 & 21.1 & 26.0 \\
\hline External 2/ & 2.9 & 3.5 & 3.9 & 5.4 & 3.8 & 4.9 \\
\hline Government-guaranteed debt & 4.3 & 8.8 & 11.0 & 13.3 & 10.3 & 10.4 \\
\hline \multicolumn{7}{|l|}{ Memorandum item: } \\
\hline GDP at current market prices & 19,249 & 21,395 & 24,689 & 28,652 & 31,740 & 33,062 \\
\hline
\end{tabular}

Sources: Namibian authorities; and Fund staff estimates.

1/ Fiscal year begins April 1. Unless otherwise indicated, data correspond to debt stocks at the end of each fiscal year.

2/ Data for 1998/99 relate to September, not March, 1999. 
Table 17. Namibia: Monetary Survey, 1998-2003

\begin{tabular}{|c|c|c|c|c|c|c|}
\hline & $\begin{array}{l}1998 \\
\text { Dec. }\end{array}$ & $\begin{array}{l}1999 \\
\text { Dec. }\end{array}$ & $\begin{array}{l}2000 \\
\text { Dec. }\end{array}$ & $\begin{array}{l}2001 \\
\text { Dec. }\end{array}$ & $\begin{array}{c}2002 \\
\text { Dec. 1/ }\end{array}$ & $\begin{array}{r}2003 \\
\text { Dec. 1/ }\end{array}$ \\
\hline & \multicolumn{6}{|c|}{ (In millions of Namibia dollars) } \\
\hline Net foreign assets & 1378.7 & 2297.7 & 2740.0 & 2551.5 & $2,083.8$ & $1,259.6$ \\
\hline Bank of Namibia & $1,488.8$ & $1,828.9$ & $1,920.8$ & $2,632.3$ & $2,886.1$ & $2,110.3$ \\
\hline Deposit money banks & -132.5 & 459.4 & 772.2 & -93.2 & -802.3 & -850.7 \\
\hline Other $2 /$ & 22.4 & 9.4 & 47.0 & 12.5 & $\ldots$ & $\ldots$ \\
\hline Net domestic assets & $5,781.8$ & $6,178.5$ & $6,834.7$ & $7,452.1$ & $10,349.9$ & $12,336.2$ \\
\hline Domestic credit & $7,418.2$ & $8,057.5$ & $9,268.2$ & $10,575.6$ & $14,932.7$ & $17,346.6$ \\
\hline Net claims on central government & 112.3 & 459.0 & 275.3 & 285.1 & -150.9 & 506.7 \\
\hline Claims on other sectors & $7,305.9$ & $7,598.6$ & $8,992.8$ & $10,290.5$ & $15,083.6$ & $16,839.9$ \\
\hline State and local government & 18.8 & 16.3 & 12.4 & 32.8 & 10.3 & 19.3 \\
\hline Public nonfinancial corporations & 142.7 & 136.6 & 234.0 & 119.1 & 225.0 & 144.3 \\
\hline Other financial corporations & 15.1 & 11.4 & 46.6 & 23.1 & 14.0 & 0.0 \\
\hline Private sector & $7,129.3$ & $7,434.2$ & $8,699.8$ & $10,115.5$ & $14,834.3$ & $16,676.3$ \\
\hline Other nonfinancial corporations (businesses) & $\ldots$ & $\ldots$ & $\ldots$ & $\ldots$ & $5,061.5$ & $6,527.0$ \\
\hline Other resident sectors (individuals) & $\ldots$ & $\ldots$ & $\ldots$ & $\ldots$ & $9,772.7$ & $10,149.3$ \\
\hline Other items, net $3 /$ & $-1,636.4$ & $-1,879.0$ & $-2,433.5$ & $-3,123.4$ & $-4,582.8$ & $-5,010.4$ \\
\hline Broad money & $7,160.5$ & $8,476.2$ & $9,574.7$ & $10,003.7$ & $12,433.7$ & $13,626.7$ \\
\hline Currency & 364.9 & 422.7 & 481.2 & 507.5 & 543.7 & 584.6 \\
\hline \multirow[t]{2}{*}{ Deposits } & $6,795.6$ & $8,053.5$ & $9,093.5$ & $9,496.2$ & $11,890.0$ & $13,042.1$ \\
\hline & \multicolumn{6}{|c|}{ (In percent change) } \\
\hline Net foreign assets & 51.5 & 66.7 & 19.2 & -6.9 & $\ldots$ & -39.6 \\
\hline Domestic credit & 3.4 & 6.9 & 10.6 & 9.0 & $\ldots$ & 19.2 \\
\hline Net claims on central government & 8.9 & 8.6 & 15.0 & 14.1 & $\ldots$ & 16.2 \\
\hline Claims on the private sector & 8.8 & 4.3 & 17.0 & 16.3 & $\ldots$ & 12.4 \\
\hline Claims on the domestic economy & 8.3 & 4.0 & 18.3 & 14.4 & $\ldots$ & 14.1 \\
\hline Broad money & 10.1 & 18.4 & 13.0 & 4.5 & $\ldots$ & 9.6 \\
\hline
\end{tabular}

Source: Bank of Namibia, Quarterly Bulletin

1/ Following Fund advice, the authorities recently revised the monetary statistics, involving several reclassification in the central and commercial bank balance sheets. As a result, no growth rates are shown for 2002.

2/ Deposit money bank and other banking institution holdings of South African rand.

3/ Includes liabilities: shares and equity, securities, loans, trade credit and advances. 
Table 18. Namibia: Summary Accounts of the Bank of Namibia, 1998-2003

(In millions of Namibia dollars)

\begin{tabular}{|c|c|c|c|c|c|c|}
\hline & $\begin{array}{l}1998 \\
\text { Dec. }\end{array}$ & $\begin{array}{l}1999 \\
\text { Dec. }\end{array}$ & $\begin{array}{l}2000 \\
\text { Dec. }\end{array}$ & $\begin{array}{l}2001 \\
\text { Dec. }\end{array}$ & $\begin{array}{r}2002 \\
\text { Dec. } 1 /\end{array}$ & $\begin{array}{r}2003 \\
\text { Dec. 1/ }\end{array}$ \\
\hline Net foreign assets & $1,488.8$ & $1,828.9$ & $1,920.8$ & $2,632.3$ & $2,886.1$ & $2,110.3$ \\
\hline Assets & $1,527.7$ & $1,876.3$ & $1,984.9$ & $2,703.5$ & $2,893.3$ & $2,117.2$ \\
\hline Liabilities & 38.8 & 47.4 & 64.2 & 71.2 & 7.2 & 6.9 \\
\hline Net Domestic assets & -879.8 & -931.5 & $-1,118.2$ & $-1,725.0$ & $-1,905.2$ & -937.5 \\
\hline Net claims on central government & -416.1 & -471.8 & -446.3 & -360.5 & $-1,114.8$ & -430.1 \\
\hline Claims on central government & 0.0 & 0.0 & 0.0 & 0.0 & 0.0 & 0.0 \\
\hline Liabilities to central government & 416.1 & 471.8 & 446.3 & 360.5 & $1,114.8$ & 430.1 \\
\hline Claims on other depository corporations & 0.0 & 0.0 & 0.0 & 0.0 & 117.5 & 95.3 \\
\hline Claims on other sectors & 0.5 & 0.7 & 0.7 & 1.1 & 16.6 & 19.0 \\
\hline State and local government & 0.0 & 0.0 & 0.0 & 0.0 & 0.0 & 0.0 \\
\hline Public nonfinancial corporations & 0.0 & 0.0 & 0.0 & 0.0 & 0.0 & 0.0 \\
\hline Other financial corporations $2 /$ & 0.5 & 0.7 & 0.7 & 1.1 & 0.0 & 0.0 \\
\hline Private sector & 0.0 & 0.0 & 0.0 & 0.0 & 16.6 & 19.0 \\
\hline Other nonfinancial corporations & 0.0 & 0.0 & 0.0 & 0.0 & 0.0 & 0.0 \\
\hline Other resident sectors & 0.0 & 0.0 & 0.0 & 0.0 & 16.6 & 19.0 \\
\hline Shares and other equity $3 /$ & -513.4 & -562.9 & -783.9 & $-1,587.9$ & $-1,103.8$ & -743.4 \\
\hline Other items, net 4/ & 49.3 & 102.5 & 111.3 & 222.2 & 179.3 & 121.7 \\
\hline Reserve money & 609.1 & 897.4 & 802.6 & 907.3 & 980.8 & $1,172.9$ \\
\hline Currency issued & 522.6 & 696.1 & 660.4 & 787.3 & 819.2 & 918.9 \\
\hline Deposits of DMBs & 86.5 & 201.3 & 142.1 & 120.0 & 161.6 & 254.0 \\
\hline Reserve accounts & 86.5 & 201.3 & 142.1 & 120.0 & 154.0 & 168.3 \\
\hline Other liabilities & 0.0 & 0.0 & 0.0 & 0.0 & 7.6 & 85.7 \\
\hline
\end{tabular}

Source: Bank of Namibia.

1/ Following Fund advice, the authorities recently revised the monetary statistics, involving several reclassification in the central and commercial bank balance sheets.

2/ Other banking institutions in old terminology

3/ Capital and reserves in old terminology

4/ Includes securities, loans and trade credit and advances 
Table 19. Namibia: Interest Rates, 1998-2003

(Annual averages in percent)

\begin{tabular}{|c|c|c|c|c|c|c|}
\hline & 1998 & 1999 & 2000 & 2001 & 2002 & 2003 \\
\hline \multicolumn{7}{|l|}{ Short-term interest rates } \\
\hline \multicolumn{7}{|l|}{ Bank rate (end of period) } \\
\hline In South Africa 1/ & 19.00 & 12.00 & 12.00 & 12.00 & 13.50 & 8.00 \\
\hline In Namibia & 18.80 & 11.50 & 11.25 & 9.25 & 12.75 & 7.75 \\
\hline Treasury bill discount rate $2 /$ & 17.30 & 13.30 & 9.65 & 9.13 & 11.37 & 10.00 \\
\hline Deposit money bank overdraft rate & 14.80 & 13.70 & 11.25 & 6.48 & 11.50 & 15.70 \\
\hline \multicolumn{7}{|l|}{ Money market rate } \\
\hline In South Africa & 17.10 & 14.00 & 9.50 & 8.00 & 11.11 & 10.93 \\
\hline In Namibia 3/ & 17.10 & 13.20 & 9.24 & 12.13 & 10.46 & 10.03 \\
\hline \multicolumn{7}{|l|}{ Treasury bill rate $2 /$} \\
\hline In South Africa & 16.50 & 13.60 & 10.11 & 9.20 & 11.16 & 10.72 \\
\hline In Namibia & 17.30 & 13.30 & 9.62 & 9.30 & 11.05 & 10.51 \\
\hline \multicolumn{7}{|l|}{ Commercial bank deposit rate 4/ } \\
\hline In South Africa & 16.50 & 13.00 & 9.70 & 8.99 & 11.33 & 10.72 \\
\hline In Namibia & 12.90 & 10.80 & 7.63 & 6.48 & 7.81 & 8.74 \\
\hline \multicolumn{7}{|l|}{ Commercial bank lending rate $5 /$} \\
\hline In South Africa & 21.80 & 18.00 & 14.50 & 13.77 & 15.58 & 15.42 \\
\hline In Namibia & 20.70 & 18.50 & 15.28 & 13.76 & 13.84 & 14.67 \\
\hline \multicolumn{7}{|l|}{ Long-term interest rate } \\
\hline Government bond yield in South Africa & 15.10 & 14.90 & 12.80 & 11.63 & 11.50 & 9.62 \\
\hline Government (five-year) bond yield in Namibia & 15.10 & 14.90 & 13.81 & 11.39 & 12.86 & 12.72 \\
\hline \multicolumn{7}{|l|}{ Memorandum items } \\
\hline \multicolumn{7}{|l|}{ Inflation } \\
\hline In South Africa 6/ & 6.89 & 5.20 & 5.10 & 5.70 & 9.16 & 5.86 \\
\hline In Namibia 6/ & 6.20 & 8.60 & 9.25 & 9.27 & 11.34 & 7.19 \\
\hline \multicolumn{7}{|l|}{ Real interest rates $7 /$} \\
\hline \multicolumn{7}{|l|}{ Commercial bank deposits } \\
\hline In South Africa & 8.99 & 7.99 & 4.77 & 3.31 & 1.83 & 4.59 \\
\hline In Namibia & 10.45 & 4.33 & 0.34 & 0.03 & -0.26 & 3.10 \\
\hline \multicolumn{7}{|l|}{ Commercial bank lending } \\
\hline In South Africa & 13.95 & 12.17 & 8.94 & 7.63 & 5.88 & 9.03 \\
\hline In Namibia & 13.65 & 9.12 & 5.52 & 4.11 & 2.24 & 6.98 \\
\hline Government bond yield in South Africa & 7.7 & 9.2 & 7.3 & 5.6 & 2.1 & 3.5 \\
\hline Government bond yield in Namibia & 8.4 & 5.8 & 4.2 & 1.9 & 1.4 & 5.2 \\
\hline
\end{tabular}

Sources: South African Reserve Bank; Bank of Namibia; and IMF, International Financial Statistics .

1/ South African Reserve Bank's repo rate.

2/ Average tender rate for 91-day bills.

3/ Money market rates in Namibia before 1996 are the same as South African rates.

4/ For South Africa, rates are upper margin of interest on time deposits of 88-91 days. For Namibia, rates are weighted averages of demand deposits, 88-day notice deposits, savings deposits, and deposits with a maturity of more than one year of two largest commercial banks.

5/ For South Africa, prime overdraft rate of major banks. For Namibia, weighted average of different lending instruments.

6/ Headline inflation for South Africa; Windhoek consumer price index for Namibia.

7/ Deflated by consumer price indices. 
Table 20. Namibia: Financial Soundness Indicators, 1998-2003

(In percent, unless otherwise indicated)

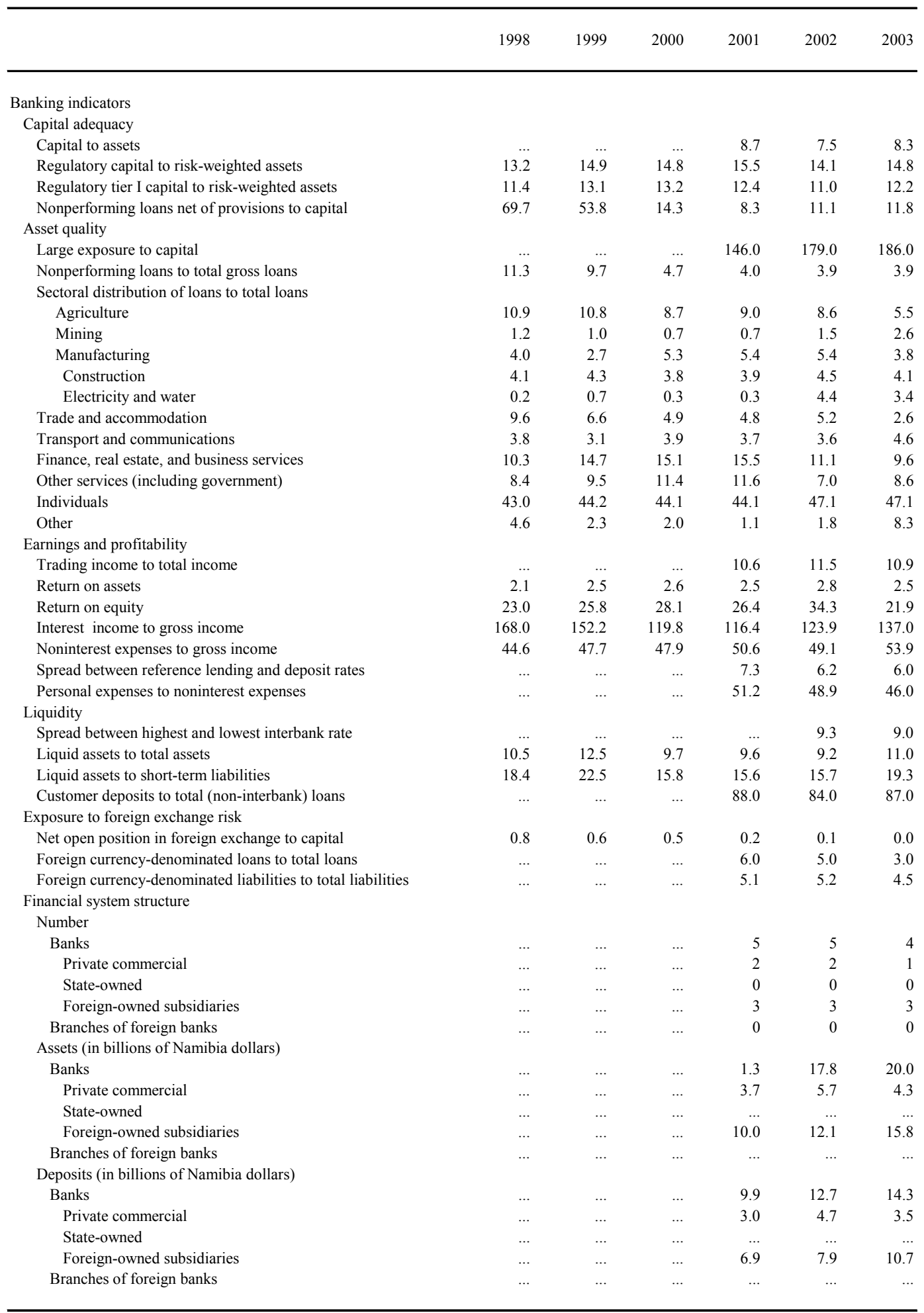


Table 21. Namibia: Selected Indicators of Stock Exchange Activity, 1998-2003

(Based on calendar years, with listings and share price figures stated as of December 31)

\begin{tabular}{|c|c|c|c|c|c|c|}
\hline & 1998 & 1999 & 2000 & 2001 & 2002 & 2003 \\
\hline \multicolumn{7}{|l|}{ Tradings on the Namibia Stock Exchange } \\
\hline Number of deals & 3,394 & 4,582 & 6,133 & 5,038 & 2,951 & 2,294 \\
\hline Volume (millions of shares traded) & 107 & 208 & 221 & 143 & 117.9 & 121.4 \\
\hline Value traded (millions of Namibia dollars) & 1,035 & 2,015 & 2,498 & 2,030 & 1,380 & 2,037 \\
\hline \multicolumn{7}{|l|}{ Listings and share price figures } \\
\hline \multicolumn{7}{|l|}{ Overall market } \\
\hline Number of listed companies overall & 40 & 41 & 41 & 37 & 35 & 35 \\
\hline Market capitalization (millions of Namibia dollars) & 159,378 & 333,916 & 337,500 & 511,651 & 386,617 & 460,315 \\
\hline Index (year-end) & 176.0 & 275.0 & 292.0 & 392.0 & 305.0 & 347.0 \\
\hline \multicolumn{7}{|l|}{ Local market } \\
\hline Number of local listed companies & 15 & 14 & 14 & 14 & 12 & 11 \\
\hline Local market capitalization (millions of Namibia dollars) & 2,515 & 4,258 & 2,326 & 1,805 & 1,728 & 2,054 \\
\hline Local index (year-end) & 106.0 & 157.0 & 92.0 & 59.0 & 47.0 & 58.2 \\
\hline
\end{tabular}

Source: Namibian Stock Exchange. 
Table 22. Namibia: Balance of Payments, 1998-2003

\begin{tabular}{|c|c|c|c|c|c|c|}
\hline & 1998 & 1999 & 2000 & 2001 & 2002 & $\begin{array}{l}2003 \\
\text { Prel. }\end{array}$ \\
\hline & \multicolumn{6}{|c|}{ (In millions of Namibia dollars; unless otherwise stated) } \\
\hline Current account & 447.9 & $1,433.8$ & $2,204.7$ & 483.5 & $1,184.0$ & $1,293.7$ \\
\hline Trade balance & $-1,579.8$ & $-1,248.5$ & 47.5 & $-1,711.4$ & $-2,183.0$ & $-3,493.4$ \\
\hline Exports, f.o.b. & $6,655.7$ & $7,313.7$ & $9,183.7$ & $9,827.6$ & $11,277.8$ & $9,450.6$ \\
\hline Of which: diamonds & $2,161.4$ & $3,022.2$ & $4,247.8$ & $4,506.5$ & $5,608.3$ & $3,864.6$ \\
\hline other minerals & $1,092.5$ & $1,123.1$ & $1,287.6$ & $1,672.4$ & $2,106.4$ & $1,381.2$ \\
\hline fish & $2,100.3$ & $1,643.1$ & $1,281.7$ & $1,354.3$ & $1,184.0$ & $1,684.0$ \\
\hline Imports, f.o.b. & $-8,235.5$ & $-8,562.2$ & $-9,136.2$ & $-11,539.0$ & $-13,460.8$ & $-12,944.0$ \\
\hline Services & -872.3 & -746.9 & $-1,010.6$ & -174.6 & 116.9 & 846.4 \\
\hline Transportation (net) & -778.7 & -706.8 & -628.3 & -706.3 & -775.0 & -456.3 \\
\hline Travel & $1,094.3$ & $1,208.7$ & 521.6 & $1,405.1$ & $1,703.8$ & $1,942.2$ \\
\hline Other services & $-1,187.9$ & $-1,248.8$ & -903.9 & -873.4 & -811.9 & -639.5 \\
\hline Income & 493.0 & 993.8 & 155.9 & -607.0 & 357.3 & 439.5 \\
\hline Compensation of employees & -13.0 & -8.3 & -9.4 & -7.5 & -13.1 & -27.3 \\
\hline Investment income & 506.0 & $1,002.1$ & 165.3 & -599.5 & 370.4 & 466.8 \\
\hline Current transfers & $2,407.0$ & $2,435.4$ & $3,011.9$ & $2,976.5$ & $2,892.8$ & $3,501.2$ \\
\hline Government (net) & $2,301.1$ & $2,306.6$ & $2,899.6$ & $2,865.0$ & $2,776.9$ & $3,341.3$ \\
\hline Of which: SACU receipts 1/ & $1,805.2$ & $2,131.8$ & $2,718.2$ & $2,700.2$ & $2,607.9$ & $2,925.9$ \\
\hline Capital and financial account & -497.4 & $-1,191.7$ & $-1,749.1$ & $-1,064.3$ & -779.3 & $-2,752.8$ \\
\hline Capital account & 251.7 & 140.0 & 777.7 & 815.7 & $1,165.7$ & 453.6 \\
\hline Financial account & -749.2 & $-1,331.8$ & $-2,526.8$ & $-1,880.0$ & $-1,945.0$ & $-3,206.4$ \\
\hline Direct investment & 420.3 & 115.3 & $1,312.0$ & $3,034.8$ & $1,857.8$ & $1,052.1$ \\
\hline Portfolio investment & -56.7 & -35.2 & -965.3 & $-1,690.8$ & $-1,975.0$ & $-2,219.7$ \\
\hline Other investment & -804.5 & $-1,062.0$ & $-2,765.0$ & $-2,505.6$ & $-1,637.4$ & $-2,814.8$ \\
\hline Of which: life insurance & -562.3 & -930.3 & $-1,114.6$ & -606.7 & -505.1 & -659.6 \\
\hline pension funds & -721.8 & -718.6 & -976.4 & -359.4 & -299.2 & -390.8 \\
\hline Reserve assets (increase -) & -308.2 & -349.9 & -108.5 & -718.4 & -190.4 & 776.0 \\
\hline Net errors and omissions & 49.6 & -242.1 & -455.6 & 580.8 & -404.7 & $1,459.1$ \\
\hline \multicolumn{7}{|l|}{ Memorandum items: } \\
\hline Current account (excluding official transfers) & $-1,853.2$ & -872.8 & -694.9 & $-2,381.5$ & $-1,592.9$ & $-2,047.6$ \\
\hline \multicolumn{7}{|l|}{ Current account/GDP (in percent) } \\
\hline Excluding current official transfers & -9.9 & -4.2 & -2.9 & -8.6 & -5.0 & -6.3 \\
\hline Including current official transfers & 2.4 & 6.9 & 9.3 & 1.7 & 3.8 & 4.0 \\
\hline International reserves (end-of-period) $2 /$ & $1,527.2$ & $1,877.1$ & $1,985.6$ & $2,704.0$ & $2,894.4$ & $2,118.4$ \\
\hline In months of imports of goods and services & 1.6 & 2.0 & 1.9 & 1.7 & 2.5 & 1.7 \\
\hline \multicolumn{7}{|l|}{ Exchange rates } \\
\hline Namibia dollars per U.S. dollar (period average) & 5.5 & 6.1 & 6.9 & 8.6 & 10.5 & 7.6 \\
\hline Namibia dollars per U.S. dollar (end-of-period) & 5.9 & 6.2 & 7.6 & 12.1 & 9.3 & 7.6 \\
\hline
\end{tabular}

Sources: Bank of Namibia; and Fund staff estimates.

1/ Southern African Customs Union.

2/ Gross foreign assets of the Bank of Namibia. 
Table 23. Namibia: Balance of Payments, 1998-2003

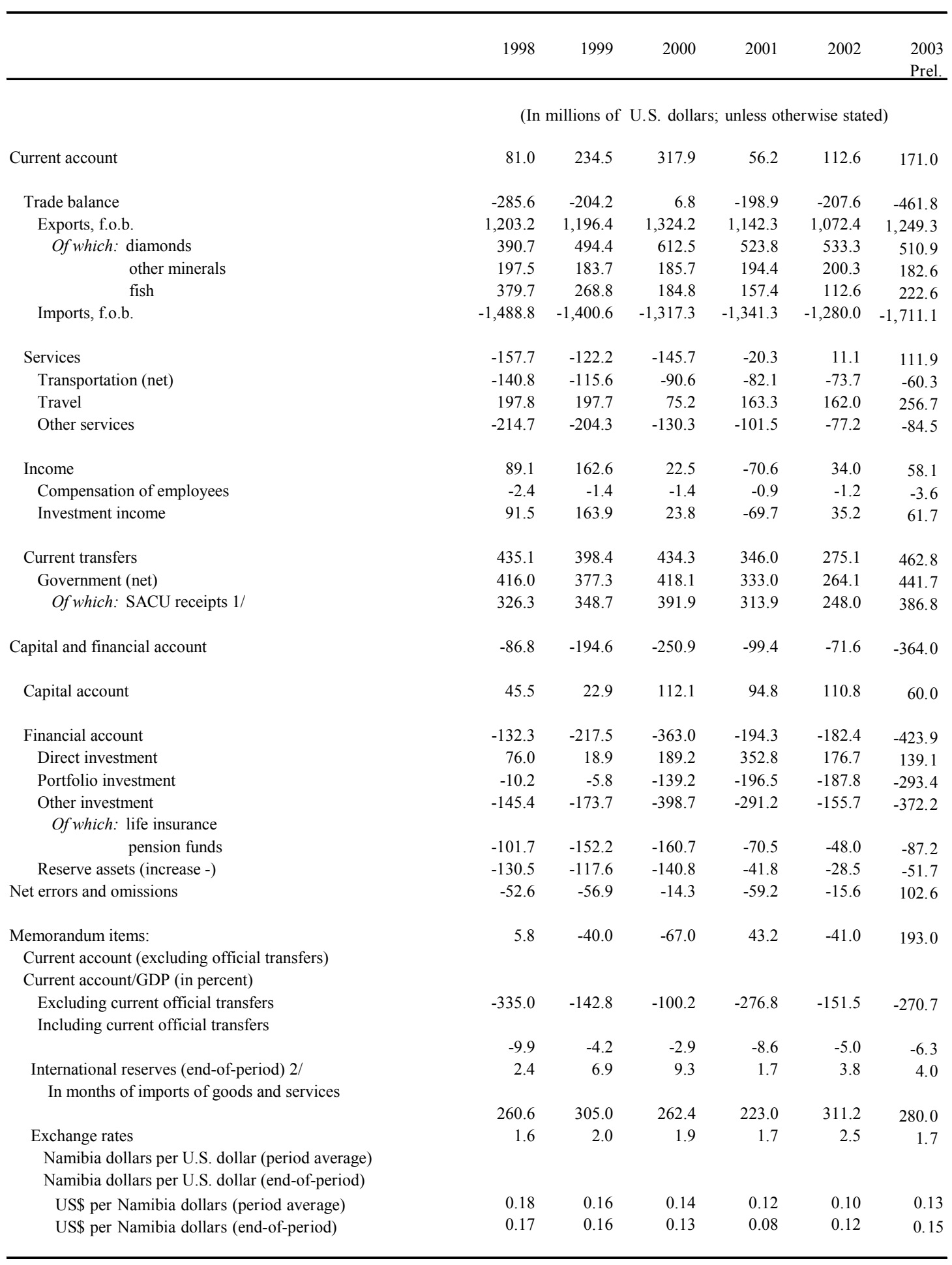

Sources: Bank of Namibia and Fund staff estimates.

1/ Southern African Customs Union.

2/ Gross foreign assets of the Bank of Namibia. 
Table 24. Namibia: Merchandise Exports by Commodity Group, 1998-2003

\begin{tabular}{|c|c|c|c|c|c|c|}
\hline & 1998 & 1999 & 2000 & 2001 & 2002 & $\begin{array}{l}2003 \\
\text { Prel. }\end{array}$ \\
\hline & \multicolumn{6}{|c|}{ (In millions of U.S. dollars) } \\
\hline Exports, f.o.b. & $1,202.5$ & $1,196.4$ & $1,324.0$ & $1,142.4$ & $1,072.0$ & $1,249.3$ \\
\hline Diamonds & 390.7 & 494.7 & 612.5 & 523.8 & 533.3 & 510.9 \\
\hline Other minerals & 197.5 & 183.7 & 185.7 & 194.4 & 200.2 & 182.6 \\
\hline Fish & 382.6 & 268.8 & 184.8 & 157.4 & 112.6 & 222.6 \\
\hline Unproceesed fish, lobster \& crab & 12.5 & 10.6 & 31.0 & 41.0 & 38.0 & 27.9 \\
\hline Processed fish & 370.1 & 258.2 & 153.8 & 116.5 & 99.3 & 201.6 \\
\hline Other manufactured products & 32.8 & 32.7 & 69.6 & 69.4 & 50.6 & 151.6 \\
\hline Live animals & 89.7 & 72.1 & 39.6 & 39.4 & 56.6 & 78.6 \\
\hline Meat \& meat preparations & 89.3 & 105.2 & 107.0 & 73.0 & 53.2 & 78.2 \\
\hline Other commodities & 19.9 & 30.4 & 104.7 & 75.3 & 21.1 & 13.1 \\
\hline Other food products & 0.0 & 8.9 & 17.1 & 9.3 & 7.5 & 4.8 \\
\hline \multirow[t]{2}{*}{ Statistical discrepancy } & $\ldots$ & $\ldots$ & 4.0 & $\ldots$ & 12.4 & $\ldots$ \\
\hline & \multicolumn{6}{|c|}{ (Annual change in percent) } \\
\hline Exports, f.o.b. & -11.7 & -0.5 & 10.7 & -13.7 & -6.2 & 16.5 \\
\hline Diamonds & -27.8 & 26.6 & 23.8 & -14.5 & 1.8 & -4.2 \\
\hline Other minerals & -21.8 & -7.0 & 1.1 & 4.7 & 3.0 & -8.8 \\
\hline Fish & 9.3 & -29.7 & -31.2 & -14.8 & -28.5 & 97.7 \\
\hline Unproceesed fish, lobster \& crab & 20.9 & -15.1 & 192.1 & 32.3 & -7.2 & -26.6 \\
\hline Processed fish & 8.9 & -30.2 & -40.4 & -24.3 & -14.7 & 103.0 \\
\hline Other manufactured products & -26.9 & -0.1 & 112.5 & -0.3 & -27.1 & 199.6 \\
\hline Live animals & 8.9 & -19.6 & -45.1 & -0.5 & 43.6 & 38.8 \\
\hline Meat \& meat preparations & 30.1 & 17.7 & 1.8 & -31.7 & -27.2 & 47.2 \\
\hline Other commodities & -11.5 & 52.6 & 245.0 & -28.1 & -71.9 & -38.0 \\
\hline \multirow[t]{2}{*}{ Other food products } & 0.0 & $\ldots$ & 92.6 & -45.5 & -19.9 & -35.3 \\
\hline & \multicolumn{6}{|c|}{ (Percent of total) } \\
\hline Exports, f.o.b. & 100.0 & 100.0 & 100.0 & 100.0 & 100.0 & 100.0 \\
\hline Diamonds & 32.5 & 41.3 & 46.3 & 45.9 & 49.7 & 40.9 \\
\hline Other minerals & 16.4 & 15.4 & 14.0 & 17.0 & 18.7 & 14.6 \\
\hline Fish & 31.8 & 22.5 & 14.0 & 13.8 & 10.5 & 17.8 \\
\hline Unproceesed fish, lobster \& crab & 1.0 & 0.9 & 2.3 & 3.6 & 3.5 & 2.2 \\
\hline Processed fish & 30.8 & 21.6 & 11.6 & 10.2 & 9.3 & 16.1 \\
\hline Other manufactured products & 2.7 & 2.7 & 5.3 & 6.1 & 4.7 & 12.1 \\
\hline Live animals & 7.5 & 6.0 & 3.0 & 3.4 & 5.3 & 6.3 \\
\hline Meat \& meat preparations & 7.4 & 8.8 & 8.1 & 6.4 & 5.0 & 6.3 \\
\hline Other commodities & 1.7 & 2.5 & 7.9 & 6.6 & 2.0 & 1.0 \\
\hline Other food products & 0.0 & 0.7 & 1.3 & 0.8 & 0.7 & 0.4 \\
\hline
\end{tabular}

Source: Bank of Namibia. 
Table 25. Namibia: Mineral Exports, 1998-2003

\begin{tabular}{|c|c|c|c|c|c|c|}
\hline & 1998 & 1999 & 2000 & 2001 & 2002 & $\begin{array}{l}2003 \\
\text { Prel. }\end{array}$ \\
\hline & \multicolumn{6}{|c|}{ (In millions of U.S. dollars) } \\
\hline Diamonds & 390.7 & 494.7 & 612.5 & 523.8 & 533.3 & 510.9 \\
\hline Copper & 9.5 & 0.0 & 8.3 & 23.3 & 24.8 & 24.3 \\
\hline Lead & 1.2 & 1.4 & 3.1 & 3.6 & 4.6 & 7.5 \\
\hline Zinc & 22.2 & 21.8 & 16.9 & 15.6 & 13.3 & 26.2 \\
\hline Silver & 2.7 & 0.0 & 2.6 & 2.9 & 6.0 & 3.7 \\
\hline Gold & 18.4 & 19.6 & 23.1 & 24.1 & 28.6 & 29.0 \\
\hline Other & 143.4 & 141.0 & 131.7 & 124.8 & 122.9 & 91.8 \\
\hline \multirow[t]{2}{*}{ Total } & 588.2 & 678.4 & 798.2 & 718.1 & 733.5 & 693.5 \\
\hline & \multicolumn{6}{|c|}{ (In percent of total) } \\
\hline Diamonds & 66.4 & 72.9 & 76.7 & 72.9 & 72.7 & 73.7 \\
\hline Copper & 1.6 & 0.0 & 1.0 & 3.2 & 3.4 & 3.5 \\
\hline Lead & 0.2 & 0.2 & 0.4 & 0.5 & 0.6 & 1.1 \\
\hline Zinc & 3.8 & 3.2 & 2.1 & 2.2 & 1.8 & 3.8 \\
\hline Silver & 0.5 & 0.0 & 0.3 & 0.4 & 0.8 & 0.5 \\
\hline Gold & 3.1 & 2.9 & 2.9 & 3.4 & 3.9 & 4.2 \\
\hline Other & 24.4 & 20.8 & 16.5 & 17.4 & 16.8 & 13.2 \\
\hline Total & 100.0 & 100.0 & 100.0 & 100.0 & 100.0 & 100.0 \\
\hline
\end{tabular}

Source: Bank of Namibia. 
Table 26. Namibia: External Trade Indices, 1998-2003

\begin{tabular}{|c|c|c|c|c|c|c|}
\hline & 1998 & 1999 & 2000 & 2001 & 2002 & $\begin{array}{c}2003 \\
\text { Prel. }\end{array}$ \\
\hline & \multicolumn{6}{|c|}{$($ Indices; $1998=100)$} \\
\hline \multicolumn{7}{|l|}{ Exports } \\
\hline Value & 100.0 & 99.4 & 110.1 & 94.9 & 89.1 & 103.8 \\
\hline Volume & 100.0 & 104.4 & 103.5 & 98.9 & 90.7 & 108.7 \\
\hline Price & 100.0 & 95.2 & 106.3 & 96.0 & 98.2 & 95.5 \\
\hline \multicolumn{7}{|l|}{ Imports } \\
\hline Value & 100.0 & 94.1 & 88.5 & 90.1 & 86.0 & 114.9 \\
\hline Volume & 100.0 & 101.4 & 96.1 & 99.9 & 113.8 & 120.1 \\
\hline Price & 100.0 & 92.8 & 92.1 & 90.2 & 75.6 & 95.7 \\
\hline \multirow[t]{2}{*}{ Terms of trade } & 100.0 & 102.6 & 115.5 & 106.5 & 130.0 & 99.9 \\
\hline & \multicolumn{6}{|c|}{ (Annual change in percent) } \\
\hline \multicolumn{7}{|l|}{ Exports } \\
\hline Value & -10.3 & -0.6 & 10.7 & -13.7 & -6.1 & 16.5 \\
\hline Volume & -0.7 & 4.4 & -0.9 & -4.5 & -8.2 & 19.8 \\
\hline Price & -9.7 & -4.8 & 11.7 & -9.7 & 2.3 & -2.7 \\
\hline \multicolumn{7}{|l|}{ Imports } \\
\hline Value & -9.5 & -5.9 & -5.9 & 1.8 & -4.6 & 33.7 \\
\hline Volume & 7.6 & 1.4 & -5.2 & 4.0 & 13.9 & 5.6 \\
\hline Price & -15.8 & -7.2 & -0.8 & -2.1 & -16.2 & 26.6 \\
\hline Terms of trade & 7.4 & 2.6 & 12.5 & -7.8 & 22.1 & -23.2 \\
\hline
\end{tabular}

Sources: Bank of Namibia; and Fund staff estimates. 
Table 27. Namibia: Merchandise Imports, by Commodity Group, 1998-2003

$\begin{array}{llllll}1998 & 1999 & 2000 & 2001 & 2002 & 2003\end{array}$

\begin{tabular}{|c|c|c|c|c|c|c|}
\hline \multirow[b]{2}{*}{ Total imports, c.i.f. } & \multicolumn{6}{|c|}{ (In millions of U.S. dollars) } \\
\hline & $1,647.4$ & $1,575.8$ & $1,478.7$ & $1,524.7$ & $1,256.0$ & $1,784.7$ \\
\hline Food, live animals, beverages, and tobacco & 309.0 & 288.4 & 240.9 & 231.1 & 208.0 & 285.7 \\
\hline Textiles, clothing, footwear & 117.1 & 108.3 & 97.0 & 84.2 & 78.2 & 111.8 \\
\hline Wood, paper and paper products, furniture & 141.9 & 129.9 & 141.2 & 115.1 & 92.9 & 131.1 \\
\hline Mineral fuels and lubricants & 102.1 & 121.2 & 137.4 & 204.0 & 147.3 & 214.8 \\
\hline Chemicals, plastic, medical, rubber & 213.9 & 215.8 & 212.1 & 253.3 & 184.7 & 259.4 \\
\hline Metal and metal products & 147.7 & 108.5 & 103.4 & 114.8 & 110.1 & 156.1 \\
\hline Machinery and electrical goods & 317.8 & 281.9 & 318.7 & 319.0 & 271.1 & 385.1 \\
\hline Vehicles and transport equipment & 321.2 & 347.5 & 251.0 & 229.7 & 189.9 & 270.2 \\
\hline All other imports & 32.2 & 27.0 & 26.8 & 21.6 & 8.7 & 19.3 \\
\hline \multirow[t]{2}{*}{ Adjustment for re-exports } & -55.5 & -52.5 & -49.9 & -48.0 & -34.9 & -48.8 \\
\hline & \multicolumn{6}{|c|}{ (In percent of total) } \\
\hline Total imports, c.i.f. & 100.0 & 100.0 & 100.0 & 100.0 & 100.0 & 100.0 \\
\hline Food, live animals, beverages, and tobacco & 18.8 & 18.3 & 16.3 & 15.2 & 16.6 & 16.0 \\
\hline Textiles, clothing, footwear & 7.1 & 6.9 & 6.6 & 5.5 & 6.2 & 6.3 \\
\hline Wood, paper and paper products, furniture & 8.6 & 8.2 & 9.5 & 7.5 & 7.4 & 7.3 \\
\hline Mineral fuels and lubricants & 6.2 & 7.7 & 9.3 & 13.4 & 11.7 & 12.0 \\
\hline Chemicals, plastic, medical, rubber & 13.0 & 13.7 & 14.3 & 16.6 & 14.7 & 14.5 \\
\hline Metal and metal products & 9.0 & 6.9 & 7.0 & 7.5 & 8.8 & 8.7 \\
\hline Machinery and electrical goods & 19.3 & 17.9 & 21.6 & 20.9 & 21.6 & 21.6 \\
\hline Vehicles and transport equipment & 19.5 & 22.0 & 17.0 & 15.1 & 15.1 & 15.1 \\
\hline All other imports & 2.0 & 1.7 & 1.8 & 1.4 & 0.7 & 1.1 \\
\hline Adjustment for re-exports & -3.4 & -3.3 & -3.4 & -3.1 & -2.8 & -2.7 \\
\hline \multicolumn{7}{|l|}{ Memorandum items: } \\
\hline Total imports, f.o.b. (in millions of U.S. dollars) & $1,488.8$ & $1,400.6$ & $1,317.3$ & $1,341.3$ & $1,280.0$ & $1,711.1$ \\
\hline Imports, f.o.b./ imports, c.i.f. (in percent) & 90.4 & 88.9 & 89.1 & 88.0 & 101.9 & 95.9 \\
\hline
\end{tabular}

Source: Bank of Namibia, and Fund staff estimates. 
Table 28. Namibia: Imports (c.i.f) by Country of Origin, 1998-2003

\begin{tabular}{|c|c|c|c|c|c|c|}
\hline & 1998 & 1999 & 2000 & 2001 & 2002 & $\begin{array}{r}2003 \\
\text { Prel. }\end{array}$ \\
\hline & \multicolumn{6}{|c|}{ (In millions of Namibia dollars) } \\
\hline Belgium & 33.3 & 31.3 & 27.1 & 43.1 & 88.1 & 59.1 \\
\hline Canada & 364.1 & 370.4 & $\ldots$ & $\ldots$ & 121.4 & $\ldots$ \\
\hline China & 34.1 & 32.0 & 45.0 & 141.4 & 121.4 & 135.6 \\
\hline France & 68.1 & 52.9 & 61.9 & 71.2 & 150.3 & 65.5 \\
\hline Germany & 267.2 & 177.8 & 194.8 & 253.8 & 426.7 & 248.9 \\
\hline India & 32.2 & 26.6 & $\ldots$ & 29.1 & 48.6 & 50.9 \\
\hline Isreal & $\ldots$ & $\ldots$ & 40.5 & 24.0 & $\ldots$ & 50.0 \\
\hline Japan & 55.5 & 32.5 & 26.3 & 23.7 & $\ldots$ & 64.0 \\
\hline Netherlands & 29.6 & 16.7 & 42.6 & 49.9 & 46.9 & $\ldots$ \\
\hline New Zealand & 82.8 & 56.1 & $\ldots$ & $\ldots$ & $\ldots$ & $\ldots$ \\
\hline Russian Federation & 103.1 & 57.7 & 40.7 & $\ldots$ & $\ldots$ & $\ldots$ \\
\hline Singapore & $\ldots$ & $\ldots$ & $\ldots$ & $\ldots$ & 141.9 & 64.4 \\
\hline South Africa & $7,430.6$ & $7,584.0$ & $8,546.5$ & $10,736.0$ & $10,507.7$ & $8,530.6$ \\
\hline Spain & 65.6 & 36.7 & 56.5 & 108.4 & 169.4 & 144.1 \\
\hline Switzerland & 34.1 & 32.0 & & 253.8 & 169.4 & 248.9 \\
\hline United Kingdom & 295.3 & 365.7 & 196.2 & 152.0 & 357.7 & 130.6 \\
\hline United States of America & 364.1 & 370.4 & 124.6 & 117.0 & 272.5 & 105.8 \\
\hline Zimbabwe & 103.1 & 57.7 & 23.0 & 46.0 & $\ldots$ & 48.2 \\
\hline Sub-total & $9,363.0$ & $9,300.7$ & $9,425.6$ & $12,049.3$ & $12,622.1$ & $9,946.6$ \\
\hline Other & 371.7 & -14.3 & 487.7 & 493.3 & 964.2 & 655.8 \\
\hline \multirow[t]{2}{*}{ Total } & $9,734.7$ & $9,286.4$ & $9,913.3$ & $12,542.6$ & $13,586.3$ & $10,602.4$ \\
\hline & \multicolumn{6}{|c|}{ (In percent of total) } \\
\hline Belgium & 0.3 & 0.3 & 0.3 & 0.3 & 0.6 & 0.6 \\
\hline Canada & 3.7 & 4.0 & $\ldots$ & $\ldots$ & 0.9 & $\ldots$ \\
\hline China & 0.4 & 0.3 & 0.5 & 1.1 & 0.9 & 1.3 \\
\hline France & 0.7 & 0.6 & 0.6 & 0.6 & 1.1 & 0.6 \\
\hline Germany & 2.7 & 1.9 & 2.0 & 2.0 & 3.1 & 2.3 \\
\hline India & 0.3 & 0.3 & $\ldots$ & 0.2 & 0.4 & 0.5 \\
\hline Isreal & $\ldots$ & $\ldots$ & 0.4 & 0.2 & $\ldots$ & 0.5 \\
\hline Japan & 0.6 & 0.3 & 0.3 & 0.2 & $\ldots$ & 0.6 \\
\hline Netherlands & 0.3 & 0.2 & 0.4 & 0.4 & 0.3 & $\ldots$ \\
\hline New Zealand & 0.9 & 0.6 & $\ldots$ & $\ldots$ & $\ldots$ & ... \\
\hline Russian Federation & 1.1 & 0.6 & 0.4 & $\ldots$ & $\ldots$ & $\ldots$ \\
\hline Singapore & $\ldots$ & $\ldots$ & $\ldots$ & $\ldots$ & 1.0 & 0.6 \\
\hline South Africa & 76.3 & 81.7 & 86.2 & 85.6 & 77.3 & 80.5 \\
\hline Spain & 0.7 & 0.4 & 0.6 & 0.9 & 1.2 & 1.4 \\
\hline Switzerland & 0.4 & 0.3 & 0.0 & 2.0 & 1.2 & 2.3 \\
\hline United Kingdom & 3.0 & 3.9 & 2.0 & 1.2 & 2.6 & 1.2 \\
\hline United States of America & 3.7 & 4.0 & 1.3 & 0.9 & 2.0 & 1.0 \\
\hline Zimbabwe & 1.1 & 0.6 & 0.2 & 0.4 & $\ldots$ & 0.5 \\
\hline Sub-total & 96.2 & 100.2 & 95.1 & 96.1 & 92.9 & 93.8 \\
\hline Other & 3.8 & -0.2 & 4.9 & 3.9 & 7.1 & 6.2 \\
\hline Total & 100.0 & 100.0 & 100.0 & 100.0 & 100.0 & 100.0 \\
\hline
\end{tabular}

Source: Central Bureau of Statistics. 
Table 29. Namibia: Exports by Country Destination, 1998-2003

\begin{tabular}{|c|c|c|c|c|c|c|}
\hline & 1998 & 1999 & 2000 & 2001 & 2002 & $\begin{array}{l}2003 \\
\text { Prel. }\end{array}$ \\
\hline & \multicolumn{6}{|c|}{ (In millions of Namibia dollars) } \\
\hline Angola & 257.8 & 296.5 & 634.2 & 603.0 & $1,944.0$ & $2,417.7$ \\
\hline Australia & $\ldots$ & 36.3 & 44.4 & $\ldots$ & 53.0 & 39.1 \\
\hline Belgium & 125.9 & 254.8 & 167.9 & 64.0 & 78.5 & 52.9 \\
\hline Botswana & $\ldots$ & 26.2 & 54.1 & 53.3 & 63.6 & 68.0 \\
\hline Canada & 52.6 & 384.0 & 204.0 & $\ldots$ & 42.5 & 95.9 \\
\hline China & 23.2 & $\ldots$ & $\ldots$ & 54.7 & $\ldots$ & 42.7 \\
\hline Congo & 100.2 & 23.9 & 29.0 & 41.8 & 95.1 & 251.2 \\
\hline France & 22.0 & 149.2 & 360.6 & 201.7 & 842.4 & 160.9 \\
\hline Germany & 54.3 & 74.2 & 95.9 & 102.2 & 153.6 & 108.3 \\
\hline Ghana & $\ldots$ & $\ldots$ & $\ldots$ & $\ldots$ & 73.7 & 100.0 \\
\hline Iceland & $\ldots$ & $\ldots$ & $\ldots$ & $\ldots$ & 126.5 & 54.1 \\
\hline Italy & 90.9 & 88.3 & 143.1 & 204.6 & 243.1 & 171.4 \\
\hline Japan & 48.7 & 73.0 & 57.5 & 79.1 & 178.9 & 55.8 \\
\hline Netherlands & 183.5 & 180.6 & 233.1 & 157.5 & 179.7 & 103.5 \\
\hline Russian Federation & $\ldots$ & 21.2 & 31.2 & $\ldots$ & $\ldots$ & 52.6 \\
\hline South Africa & $1,941.4$ & $2,313.1$ & $2,328.8$ & $2,471.7$ & $3,396.8$ & $3,057.0$ \\
\hline Spain & 950.1 & $1,035.5$ & 918.6 & $1,538.1$ & $1,622.8$ & $1,242.8$ \\
\hline Switzerland & 411.7 & 266.5 & 286.1 & $\ldots$ & 40.7 & 48.0 \\
\hline United Kingdom & $1,182.4$ & $2,301.8$ & $2,996.2$ & $4,103.4$ & $3,281.7$ & $1,009.6$ \\
\hline United States of America & 277.1 & 230.9 & 274.1 & 346.0 & 421.2 & 261.7 \\
\hline Zimbabwe & 37.8 & 29.1 & 27.7 & 36.4 & $\ldots$ & $\ldots$ \\
\hline Sub-total & $5,759.6$ & $7,785.0$ & $8,886.3$ & $10,057.5$ & $12,837.9$ & $9,393.1$ \\
\hline Other & 690.1 & 220.0 & 271.7 & 391.7 & 522.0 & 308.8 \\
\hline \multirow[t]{2}{*}{ Total } & $6,449.6$ & $8,005.0$ & $9,158.0$ & $10,449.2$ & $13,359.9$ & $9,701.9$ \\
\hline & \multicolumn{6}{|c|}{ (In percent of total) } \\
\hline Angola & 4.0 & 3.7 & 6.9 & 5.8 & 14.6 & 24.9 \\
\hline Australia & $\ldots$ & 0.5 & 0.5 & $\ldots$ & 0.4 & 0.4 \\
\hline Belgium & 2.0 & 3.2 & 1.8 & 0.6 & 0.6 & 0.5 \\
\hline Botswana & $\ldots$ & 0.3 & 0.6 & 0.5 & 0.5 & 0.7 \\
\hline Canada & 0.8 & 4.8 & 2.2 & $\ldots$ & 0.3 & 1.0 \\
\hline China & 0.4 & $\ldots$ & $\cdots$ & 0.5 & $\ldots$ & 0.4 \\
\hline Congo & 1.6 & 0.3 & 0.3 & 0.4 & 0.7 & 2.6 \\
\hline France & 0.3 & 1.9 & 3.9 & 1.9 & 6.3 & 1.7 \\
\hline Germany & 0.8 & 0.9 & 1.0 & 1.0 & 1.1 & 1.1 \\
\hline Ghana & $\ldots$ & $\ldots$ & $\ldots$ & $\ldots$ & 0.6 & 1.0 \\
\hline Iceland & $\ldots$ & $\ldots$ & $\cdots$ & $\ldots$ & 0.9 & 0.6 \\
\hline Italy & 1.4 & 1.1 & 1.6 & 2.0 & 1.8 & 1.8 \\
\hline Japan & 0.8 & 0.9 & 0.6 & 0.8 & 1.3 & 0.6 \\
\hline Netherlands & 2.8 & 2.3 & 2.5 & 1.5 & 1.3 & 1.1 \\
\hline Russian Federation & $\ldots$ & 0.3 & 0.3 & $\ldots$ & $\ldots$ & 0.5 \\
\hline South Africa & 30.1 & 28.9 & 25.4 & 23.7 & 25.4 & 31.5 \\
\hline Spain & 14.7 & 12.9 & 10.0 & 14.7 & 12.1 & 12.8 \\
\hline Switzerland & 6.4 & 3.3 & 3.1 & $\ldots$ & 0.3 & 0.5 \\
\hline United Kingdom & 18.3 & 28.8 & 32.7 & 39.3 & 24.6 & 10.4 \\
\hline United States of America & 4.3 & 2.9 & 3.0 & 3.3 & 3.2 & 2.7 \\
\hline Zimbabwe & 0.6 & 0.4 & 0.3 & 0.3 & $\ldots$ & $\ldots$ \\
\hline Sub-total & 89.3 & 97.3 & 97.0 & 96.3 & 96.1 & 96.8 \\
\hline Other & 10.7 & 2.7 & 3.0 & 3.7 & 3.9 & 3.2 \\
\hline Total & 100.0 & 100.0 & 100.0 & 100.0 & 100.0 & 100.0 \\
\hline
\end{tabular}

Source: Central Bureau of Statistics.

CInternational Monetary Fund. Not for Redistribution 
Table 30. Namibia: Developments in the Exchange Rate of the Namibia Dollar, 1995-2004

(Period average; $1995=100)$

\begin{tabular}{|c|c|c|c|c|c|c|}
\hline & \multicolumn{2}{|c|}{ Effective Exchange Rate } & \multirow[b]{2}{*}{ U.K. Pound } & & \multirow{2}{*}{$\begin{array}{r}\text { Botswana } \\
\text { Pula } \\
\end{array}$} & \multirow{2}{*}{$\begin{array}{r}\text { Zimbabwe } \\
\text { Dollar }\end{array}$} \\
\hline & \multirow[t]{2}{*}{ Nominal } & \multirow[t]{2}{*}{ Real } & & U.S. Dollar & & \\
\hline & & & \multicolumn{4}{|c|}{ (Namibia dollar per foreign currency index) } \\
\hline 1995 & 100.0 & 100.0 & 100.0 & 100.0 & 100.0 & 100.0 \\
\hline 1996 & 94.9 & 97.4 & 117.1 & 118.5 & 98.8 & 103.3 \\
\hline 1997 & 93.7 & 98.8 & 131.8 & 127.0 & 96.5 & 91.3 \\
\hline 1998 & 87.6 & 93.3 & 159.9 & 152.4 & 99.9 & 55.8 \\
\hline 1999 & 84.2 & 94.1 & 172.6 & 168.4 & 100.9 & 38.1 \\
\hline 2000 & 82.5 & 96.9 & 183.4 & 191.3 & 104.0 & 37.3 \\
\hline 2001 & 77.3 & 95.2 & 216.3 & 237.1 & 112.6 & 37.3 \\
\hline 2002 & 69.8 & 90.4 & 275.7 & 290.5 & 127.9 & 45.7 \\
\hline 2003 & 76.4 & 101.8 & 215.5 & 208.4 & 118.4 & 7.9 \\
\hline \multicolumn{7}{|l|}{2004} \\
\hline January & 75.7 & 101.8 & 221.6 & 192.0 & 114.8 & 0.4 \\
\hline February & 76.2 & 103.3 & 220.6 & 186.5 & 107.0 & 0.4 \\
\hline March & 77.5 & 104.8 & 211.9 & 183.0 & 109.0 & 0.5 \\
\hline April & 78.3 & 105.9 & 207.3 & 181.5 & 101.3 & 0.3 \\
\hline May & 77.4 & 104.8 & 212.8 & 188.1 & 109.4 & 0.4 \\
\hline June & 77.7 & 104.8 & 204.8 & 176.9 & 105.0 & 0.4 \\
\hline July & 80.6 & 109.6 & 196.8 & 168.7 & 100.2 & 0.3 \\
\hline August & 80.4 & 109.8 & 205.2 & 178.0 & 101.3 & 0.4 \\
\hline September & 77.4 & 106.6 & 205.5 & 180.9 & 104.6 & 0.3 \\
\hline October & 76.9 & 105.6 & 200.6 & 175.3 & 103.4 & 0.3 \\
\hline November & 77.3 & 105.8 & 197.6 & 167.7 & 103.1 & 0.3 \\
\hline
\end{tabular}

Sources: IMF, Information Notice System; and Fund staff calculations. 
Namibia: Summary of the Central Government Tax System, November 2004

(All amounts in Namibia dollars)

Tax

Nature of Tax

Exemptions and Deductions

Rates

1. Taxes on net income and profits

1.1. Taxes on companies 1.11 Company income tax

(Income Tax Act No. 24 of 1981, as amended)
Income tax is levied on the taxable income of any company registered in

Namibia and on the taxable income generated in Namibia by foreign companies. Taxable income is defined as gross income less allowable deductions and loss offsets. The year of assessment is the financial year of the company. Companies are required to make two provisional tax payments in respect of each year of assessment, i.e., the first within six months after the commencement of the year of assessment, and the second at the end of such year.

Companies are subject to selfassessment and must render returns of income within 210 days after the end of the year of assessment. Each return must include a computation of taxable income and of the amount of tax

payable (to-up-payment). Any tax due must be paid simultaneously with the furnishing of the return. Any shortfall will attract interest as from the first day following the 210 days after the end of the assessment year.
Deductions include normal operating costs and interest, but exclude dividends declared and capital expenditures.

Capital expenditure allowances

granted to nonmining companies are as follows:

Expenditure incurred during the year of assessment in respect of

machinery, implements, utensils, and articles used by the taxpayer for the purposes of his trade is allowed as follows: one-third in the year of acquisition, one-third in the second year; and one-third in the third year.
Nonmining: 35 percent on taxable income derived in Namibia for years of assessment commencing on or after 1/1/99.

All mining except diamond mining:

37.5 percent on taxable income derived for years of assessment commencing on or after $1 / 1 / 2000$. 
Namibia: Summary of the Central Government Tax System, November 2004

(All amounts in Namibia dollars)

Comprehensive agreements for the avoidance of double taxation and fiscal evasion ratified, published, and in force: South Africa, Germany, France, Sweden, India, Mauritius, Romania, and Russia.

An old, pre-independence agreement with the UK is still honored, but a new treaty is expected to be finalized soon.

The following agreements are in various stages of finalization: Singapore, Tunisia, Zimbabwe, Malaysia, Botswana, and Poland.

Mining companies are subject to special taxation provisions.

(Comment: The revised strategy with respect to double taxation and fiscal evasion agreements is to first concentrate and prioritize on treaties within SACU and SADC, before embarking upon any further bilateral agreements.)

Tax incentives are granted to manufacturing enterprises and to exporters of manufactured goods (excluding fishing and meat products). Eighty percent of the profits resulting from the export of qualifying manufactured goods are exempt from income tax. An allowance of 25 percent in respect of land-based transportation costs is provided.
The principal assets on which depreciation is not allowed are intangible assets such as goodwill, patents, and trademarks. However, the cost of patents and trademarks can be written off over the expected life of the patent or trademark or 25 years, whichever is the lesser.

Capital expenditure initial and annual allowances for buildings are as follows:

In respect of buildings used by the taxpayer for the purposes of his trade, a deduction of 20 percent of the cost of erection of the building is allowed in the year in which it is brought into use, and 4 percent a year for 20 years following the year of erection.

However, in the case of a manufacturer, the initial deductions following the 20 percent are enhanced to 8 percent for the following 10 years.
Diamond mining: 50 percent of taxable income plus a surcharge of 10 percent, yielding an effective rate of 55 percent.

The rate of taxation was extended to companies rendering services in connection with mining for diamonds on behalf of any person licensed to conduct such mining operations as from January 1995.

Registered manufacturers, 18 percent on taxable income derived for years of assessment commencing on or after $1 / 1 / 2003$. 
Namibia: Summary of the Central Government Tax System, November 2004

(All amounts in Namibia dollars)

Tax
Nature of Tax
Exemptions and Deductions
Rates
1.2 Taxes on individuals

1.21 Individual income tax: general

(Income Tax Act No. 24 of 1981)
Wage and salary earners are subject to a withholding tax at source (pay-asyou-earn). Self-employed taxpayers are registered as provisional

taxpayers. Provisional taxpayers are required to estimate their income for the year of assessment, calculate tax thereon, and pay this amount of tax in two half-yearly installments. Capital gains are not subject to tax. Dividends are tax exempt, except building society dividends. Interest received on investments with NamPost are exempted from tax (companies do not enjoy this exemption)

Individuals (excluding those wage and salary earners who do not have to render returns) are subject to selfassessment on the same basis as companies.

\section{Capital expenditure allowances for} mining companies are as follows:

Capital expenditure consists of development and exploration expenditure. Exploration expenditure can be written off in full in the assessment year during which it is incurred. Development expenditure can be deducted on the following basis: onethird in the assessment year in which the expenditure is incurred; one-third in the ensuing assessment year; and one-third in the second ensuing assessment year.

Individuals may deduct an aggregate of $\mathrm{N} \$ 30,000$ from their gross income in respect of contributions to retirement annuity funds, provident and/or pension funds, and premiums paid on educational policies for their children.

Husbands and wives are taxed independent of each other.
The tax payable is calculated by applying the rates shown below to the taxable amount.

The tax rates are as follows: 
Namibia: Summary of the Central Government Tax System, November 2004

(All amounts in Namibia dollars)

Persons whose income comprises remuneration for a full year of assessment from one employer and who are not entitled to deductions incurred in the production of income and who receive interest income of less than $\mathrm{N} \$ 500$ are not required to submit returns of income.

Assessments will be issued to such persons on the basis of information received from their employers.

Refunds due on income tax, valueadded tax,_sales tax, and additional sales levy may be set off against any other tax, levy, interest, or penalty that is administered by the minister before any payment is made to the taxpayer.
Taxable amount:

where the taxable

amount

does not exceed

$\mathrm{N} \$ 24,000$,

exceeds

$\mathrm{N} \$ 24,000$ but

does not exceed

$\mathrm{N} \$ 40,000$,

exceeds

$\mathrm{N} \$ 40,000$, but

does not exceed

$\mathrm{N} \$ 80,000$,

exceeds

$\mathrm{N} \$ 80,000$, but

does not exceed

N\$200,000,

exceeds

$\mathrm{N} \$ 200,000$.
Rates of tax:

no tax payable;

17.5 percent of the amount over N $\$ 24,000$

N\$2,800 plus 29.5 percent of the amount by which the taxable amount exceeds $N \$ 40,000$.

$\mathrm{N} \$ 14,600$ plus 34.5 percent of the amount by which the taxable amount exceeds $\mathrm{N} \$ 80,000$;

$\mathrm{N} \$ 56,000$ plus35 percent of the amount by which the taxable amount exceeds N\$200,000. 
Namibia: Summary of the Central Government Tax System, November 2004

(All amounts in Namibia dollars)

Tax
Nature of Tax
Exemptions and Deductions

Rates

1.3 Other

1.31 Taxes on royalties

and know-how

(Income Tax Act No. 24

of 1981)

1.32 Tax on

nonresidential

shareholders

(Income Tax Act No. 24

of 1981)

2. Taxes on property

2.1 Property transfer taxes (Transfer Duty Act

No. 14 of 1993)
Property transfer taxes are taxes payable on the purchase consideration or fair value (whichever is the greater) of transfers of immovable property.
Normal tax rate applicable to companies, computed on 30 percent of the royalty paid.

Tax on nonresidential shareholders is a tax on dividend income derived by nonresidents. The tax is withheld by the company declaring the dividends.

10 percent on the amount of the dividend.

\section{Transfer duty:}

Where the said value or the said amount, as the case may be-

$>$ Does not exceed N\$ 100 000, nil per cent;

$>$ Exceeds N\$100 000 but does not exceed N\$ 200000 , one per cent of so much of the said

value or the said amount, as the case may be, as

exceeds N\$ 100 0000;

$>$ Exceeds N\$200 000 but does not exceed N\$400 000, N\$1 000 plus five per cent of so much of the said value amount, as the case may be, as exceeds N\$200 000;

$>$ Exceeds N\$400 000, N\$11 000 plus eight per cent of so much of the said value or the said amount, as the case may be, as exceeds $\mathrm{N} \$ 400000$, 
3.0 Taxes on goods and services

(General Comment: The former General Sales

Tax and the Additional

Sales taxes were

repealed on November

26, 2000 and substituted by the Value-Added Tax System)
An invoice based VAT system is applied.

\section{Denial of input tax deduction}

A registered person is not entitled to claim input tax on the following:

- Entertainment, unless the person is in business as a tour operator or supplies entertainment, or is a transport operator as part of a taxable service.
In the case of the acquisition of agricultural land by a person to whom an advance for the purposes of such acquisition is made by the Agricultural Bank of Namibia, in accordance with the provisions of Section 46(1)(a) of the Agricultural Bank Act, 1944 (Act 13 of 1944)

$>$ does not exceed N\$ 100000 , nil per cent;

$>$ exceeds N\$100 000 but does not exceed N\$ 200000 , one per cent of so much of the value of the agricultural land as exceeds $\mathrm{N} \$ 100000$;

$>$ exceeds N\$200 000, N\$ 1000 plus three per cent of so much of the value of the agricultural land as exceeds N\$200 000;

Eight per cent of the said value or the said amount, as the case may be, if the person by whom the property is acquired or in whose favour or for whose benefit the said interest or restriction is renounced is a person other than a natural person.

Transactions (supplies) that are not exempt are taxable supplies and are subject to VAT at one of two rates:

- a standard rate of 15 percent

- a zero rate of 0 percent 
3.1 Value-Added Tax (VAT Act, 2000, Act. No. 10$)$
- "Entertainment" means the provision of food, beverages, tobacco, accommodation or hospitality of any kind.

- Subscription and membership of any sporting, social or recreational nature.

- Passenger vehicles, unless such supplier is in the business of dealing in or hiring of vehicles, or is a tour operator, or the vehicles are acquired for the purpose of business or acquired by a short-term insurer for indemnification.

- "Passenger vehicle" means a vehicle designed for adopted and used solely for the transport of nine or fewer seated persons, including double cab vehicles.

- Petroleum products, unless wholly for use in the business.

\section{Zero-rated supplies}

A registered person making a zero-rates supply charges VAT a 0 percent on the supply and is entitled to recover the input tax on goods and services acquired to make such supplies.

Goods and services exported are normally treated as zero-rated supplies, as are

- International transport services to persons and goods

- Leaded or unleaded petrol, distillate fuels, etc. bring goods subject to the fuel levy

- Services to a non-resident person who is not a registered person for the arranging of goods to be exported from Namibia and transport of goods within Namibia

- Services physically rendered outside Namibia

- Supply of services to a non-resident person who is outside Namibia at the time of service, other than

- Directly in connection with immovable property situated in Namibia

- Directly in connection with moveable property in Namibia unless subsequently exported, or

○ By a tour operator 
Namibia: Summary of the Central Government Tax System, November 2004

(All amounts in Namibia dollars)

\section{Exemption supplies}

A person who makes exempt supplies only, is not a taxable person and cannot be registered. VAT is not charged on supplies and no amount may be recovered in respect of input tax.

Goods and services exempted:

\section{- Interest}

Educational services

- Residential accommodation

$$
\text { Unit trusts }
$$

- Long-term insurance contracts and the arranging thereof

- Public transport of passengers (excluding tour operators)

- Margin-based financial services

- Asset management services

- Intermediation services and management of medical aid fund and buy-aid society

- Medical services

- Services supplied by a body corporate to its members

- Services by a trade union
- Supply of taxable activity as a going concern

- Mahango, mahango meal and maize meal

- Supply of goods and services by charitable organizations

- Telecommunication services to a foreign operator

- The sale of immovable property or the erection of or extension to a building, used or to be used for residential purposes

- $\quad$ Supply of postage stamps excluding collector's pieces

- Supply of electricity, water, refuge removal and sewerage to a residential account

- $\quad$ Parts and services rendered in pursuance of any guarantee of new goods

- Telecommunication services to residential accounts.

- A supply of livestock (other than game)

- A supply of

- Goods (excluding any other than an invalid vehicle carriage) designed, 
- Services in the ordinary course of operation a registered hospital, maternity home, nursing home, or clinic

- Supplies to foreign Heads of State

- Fringe benefits to employees

- Supply of a benefit fund, retirement annuity fund, pension fund, preservation fund and provident fund and the arranging and management thereof

\section{Exempt imports}

○ Import of goods and services by $\mathrm{Z}$ enterprise or EPZ management company

- Certain goods for welfare or charitable purposes

- Goods originally exported from Namibia (and not zerorated when exported) and then brought back by the exporter without having been subjected to any manufacturing process or permanent change in ownership manufactured, adjusted or modified solely as aids or devices for the use of any physically handicapped person who is blind, deaf or crippled or is a chronic invalid; or

- Repair or maintenance services rendered in respect of goods and parts and materials required to effect such services; or

- Adjustment or modification services rendered in respect of any vehicle intended for the use of any physically handicapped person where such service is required solely to enable such person to operate such vehicle, and parts and materials required to effect such services.

- A supply of agricultural land to the State to be used solely for resettlement purpose

- A supply of water to or by a local water committee approve by the Minister of Agriculture, Water and Rural Development 
Namibia: Summary of the Central Government Tax System, November 2004

(All amounts in Namibia dollars)

- Imported or locally

manufactured returned empty

packing containers

- Goods sent abroad for

processing or repair,

exported under customs and

excise supervision, and

retaining their essential

character, returned to the

exporter

- Used personal or household

effects (excluding motor

vehicles) bequeathed to

- Goods temporarily imported

for processing, provided

they do not become the

property of the importer

- Goods temporarily imported

for specified purposes

- Goods imported as

accompanied passengers'

baggage

- An import of goods

(excluding any vehicle other

than an invalid carriage) by

any person (other than a

registered person) designed, 
3.2 Selective Excises (Customs and Excise Act No. 20 of 1998, as amended)

Duties are payable by the manufacturer or importer of certain commodities. Most are specific, but some ad valorem rates exist.
- manufactured, adjusted or modified solely as aids or devices for the use of any physically handicapped person who is blind, deaf or crippled or is a chronic invalid;

- An import of goods which are donated to the State

- An import of goods or services by the State.

A rebate is granted on dutiable goods For alcohol products, the following rates are in that are used by diplomatic

representatives, etc., and on taxable goods used by producers in the manufacture of taxable goods for industrial or commercial purposes. effect:

- for beer made from malt: 3,073.04c per liter of absolute alcohol;

- for wine, fortified and sparkling rates vary from $232.87 \mathrm{c}$ to $323.32 \mathrm{c}$ per liters;

- for spirits rates, $4,583.65 \mathrm{c}$ per liters.

The following rates apply to manufactured

tobacco products:

- for cigars, $132,304 \mathrm{c}$ per kg net;

- for cigarettes, $226.40 \mathrm{c}$ per 10 ; and

- for cigarette tobacco, $13,903 \mathrm{c}$ per kg.

The following rates apply to petrol products:

- Excise and customs duty, 0c per liter;

- Fuel levy, 12c per liter.

The following rates apply to diesel products:

- Excise and customs duty, 0c per liter:

- Fuel levy, 10c per liter. 
Namibia: Summary of the Central Government Tax System, November 2004

(All amounts in Namibia dollars)

Tax

Nature of Tax

Exemptions and Deductions

Rates

4.1 Customs duties

(Customs and Excise Act

No. 20 of 1984, as

amended)
5. Other taxes
5.1 Stamp duties
(Stamp Duties Act No.
15 of 1993)

\begin{abstract}
A three-column tariff schedule based on the Brussels nomenclature with general, most favored nation, and preferential rates of duty is applied. Preferential treatment is given to goods from the United Kingdom and, in some cases, goods from Canada and Ireland. Namibia is in a customs union with South Africa, Botswana,

Lesotho, and Swaziland.

Most duties are assessed ad valorem at f.o.b. value, but there are a number of specific duties.
\end{abstract}

Ad valorem or specific taxes are payable on a wide range of legal documents, such as agreements, bills of exchange, bonds, fixed-deposit receipts, leases, marketable securities, and transfer deeds.
Rebates are allowed for certain goods used in manufacture by approved industries or by particular institutions and bodies.
Import duties vary widely.
Most securities issued by certain public corporations and public authorities are exempt from stamp duty on issue and transfers. Where a marketable securities tax is

chargeable, brokers' notes do not attract stamp duty.
Rates of stamp duty vary for different instruments and also for a particular instrument. Examples are agreements of lease (N\$5-15 per N\$1,000); bills of exchange (N\$2 per $\mathrm{N} \$ 1,000)$; and fixed-deposit receipts $(\mathrm{N} \$ 1$ per $\mathrm{N} \$ 1,000)$.

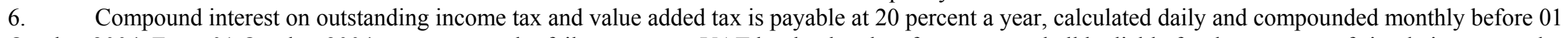

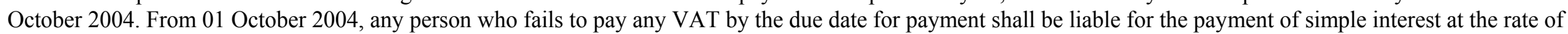

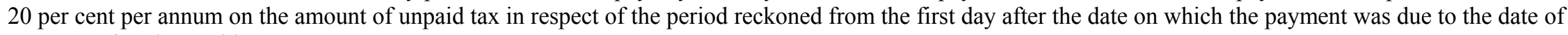
payment of such unpaid amount.

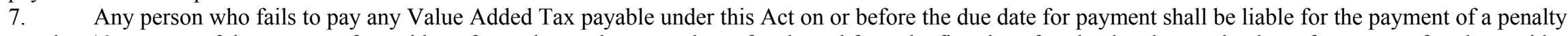

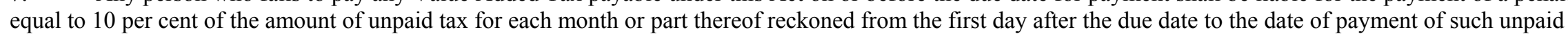
amount.

Source: Ministry of Finance. 